\title{
POLA PERJALANAN WISATAWAN TIMUR TENGAH BERDASARKAN PROFIL WISATAWAN DAN MOTIVASI POLA PERGERAKAN DI BANDUNG
}

\author{
Nukeu Novia Andriani S ${ }^{1}$, Aji Prasetya $\mathrm{Hadi}^{2}$ \\ ${ }^{I}$ Pengelolaan Konvensi dan Acara,Wilmar Bisnis Indonesia, Medan,nukeu.andriani@,wbi.ac.id \\ ${ }^{2}$ Pengelolaan Konvensi dan Acara, Wilmar Bisnis Indonesia, Medan, aji.prasetya@wbi.ac.id
}

\begin{abstract}
ABSTRAK:
Penelitian ini menganalisis tentang bagaimana pola perjalanan wisatawan Timur Tengah berdasarkan profil wisatawan dan motivasi pola pergerakan di Bandung. Tujuan penelitian ini adalah untuk mengetahui bagaiman pola perjalanan wisatawan Timur Tengah berdasarkan profil wisatawan dan motivasi pola pergerakan di Bandung sehingga dapat menjadi bahan informasi bagi pemerintah daerah, pelaku usaha pariwisata dan perjalanan dalam upaya meningkatkan jumlah kunjungan wisatawan Timur Tengah di Bandung. Metode penelitian yang digunakan adalah metode penelitian deskriptif dengan pendekatan kualitatif, dengan informan berjumlah 3 wisatawan Timur Tengah.Pengumpulan data dilakukan melalui observasi, analisis dokumen, wawancara dengan wisatawan Timur Tengah.Data tersebut dianalisis menggunakan coding untuk mengkategorikan informasi, menemukan pola dan menghubungkan dengan beberapa kategori, dan interpretasi data yang melalui beberapa sumber terkait.Penelitian ini menunjukkan bahwa profil wisatawan Timur Tengah yang tergolong wisatawan kelas menengah keatas dan termasuk kedalam tipologi wisatawan near phsichocentric dan cenderung mendekati Mid-centric sangat memiliki ketertarikan untuk menjelajahi daya tarik wisata yang ada di Bandung.Namun Bandung masih di ada yang harus diperbaiki terutama berkenaan dengan kurangnyatenaga ahlidisektorpariwisatayangdapatberbahasaArab.
\end{abstract}

KataKunci:PolaPerjalanan,ProfilWisatawan,MotivasiPolaPerjalanan, WisatawanTim urTengah

\section{ABSTRACT}

This study analyses how the Middle East tourists travel patterns in Bandung based on tourist profile and motivation movement patterns. The purpose of this studies to investigate how Middle East tourist travel patterns based on tourist profile and motivation movement patterns in Bandung. This research used descriptive with 


\section{National Conference of Creative Industry: Sustainable Tourism Industry for Economic Development \\ Universitas Bunda Mulia, Jakarta, 5-6 September 2018 \\ ISSN No: 2622-7436}

qualitative approach, involving 3 Middle East tourists as informants. The data were analyses by assigning codes to categorize information, identifying patterns and connection between categories, and interpreting the data from the multiple sources. This result show that the Middle East tourist profiles belonging to middle and upper class tourist and based on the tourist typology, Middle East tourist include into the category of near phischocentric and tend to approach the Mid-centric. Middle East tourist very interested to explore tourist attraction in Bandung. However Bandung still need to be improved, especially some points related to the limitation of professional expertise in several tourism service sectors who able to perform and speak Arabic well.

Keywords: Travel pattern, Tourist profile, Travel pattern motivation, Middle East Tourist

\section{PENDAHULUAN}

Bandung merupakan salah satu kota yang memiliki daya tarik wisata yang cukup tinggi. Beragam jenis wisata tersedia di Kota Bandung, salah satunya yaitu ; Wisata Belanja, Wisata Budaya, Wisata Kuliner dan berbagai Wisata Alam. Bandung memiliki iklim yang sejuk mengingat topografi daerahnya yang dikelilingi pegunungan.Kondisi alam yang mendukung serta keramahan masyarakat yang santun seolah menempatkan berbagai tempat wisata di Bandung sebagai tujuan wisata favorit.

Berdasarkan RIPPARNOV Provinsi Jawa Barat 2015-2025 tentang pembangunan pemasaran pariwisata yang bertanggung jawab dengan berbasis pada riset pasar dan pemanfaatan teknologi informasi dan komunikasi. Menetapkan bahwa wisatawan Timur Tengah merupakan sebagai pasar utama yang akan di bidik oleh pemerintah Jawa Barat, dengan meningkatkan lama tinggal atau length of stay selama 7 hari.

Pemerintah Kota Bandung membidik negara-negara di Timur Tengah untuk memperluas target wisatawan guna tercapainya target 2,6 juta wisatawan mancanegara ke Kota Bandung. Berdasarkan Badan Pusat Statistik tentang kunjungan 


\section{National Conference of Creative Industry: Sustainable Tourism Industry for Economic Development}

Universitas Bunda Mulia, Jakarta, 5-6 September 2018

ISSN No:

wisatawan Timur Tengah pada tahun 2010 sebesar 144.661, pada tahun 2011 mengalami kenaikan sebesar 175.885, walaupun pada tahun 2012 mengalami penurunan menjadi 148,788 namun ditahun 2013 wisatawan Timur Tengah mengalami peningkatan jumlah kunjugan kembali dengan total 188.675 dan di 2014 dengan total kunjungan wisatawan sebesar 195.518. (Badan Pusat Statistik : 2015).

Sedangkan menurut data survey BAPPENAS 2016wisatawan asal Timur Tengah merupakan wisman yang memiliki rerata pengeluaran harian tertinggi di bandingkan dengan Asia, Eropa dan Oseania.Dilihat dari data berikut, wisatawan Timur Tengah memiliki potensi yang baik untuk dijadikan target pasar kepariwisataan khususnya di Kota Bandung.

Berikut data pra survey yang dilakukan di Sensa Hotel Bandung dari tahun 2013 sampai dengan September 2016 dan Best Western Hotel Bandung selama bulan Januari sampai dengan Oktober 2016.

Tabel 1.1

Jumlah tamu Timur Tengah di Sensa Hotel

\begin{tabular}{|c|c|c|}
\hline Year to Date & Room Night & Guest inhouse \\
\hline 2013 & 506 & 1012 \\
\hline 2014 & 2007 & 4014 \\
\hline 2015 & 4464 & 8928 \\
\hline Jan - Sep 2016 & 6208 & 12416 \\
\hline
\end{tabular}

(Sumber : Sensa Hotel, 2016)

Tabel I.2

Jumlah tamu Timur Tengah di Best Western Hotel.

\begin{tabular}{|c|c|c|}
\hline Year to Date & Room Night & Guest Inhouse \\
\hline Jan - Okt 2016 & 372 & 744 \\
\hline
\end{tabular}

(Sumber : Best-Western Bandung)

Data Guest inhouse merupakan hasil dari asumsi peneliti, karena berdasarkan survey lapangan tidak adanya ke akuratan berapa jumlah total pengunjung yang menginap di hotel hotel tersebut.

Berdasarkan data diatas kedatangan tamu Timur Tengah mengalami kenaikan 2 kali lipat disetiap tahunya dengan length of stay atau lama menginapdibandung hanya 2 hari 1 Malam. Ini merupakan paling sedikit dibandingkan ketika menginap di Puncak dengan length of stay 5 hari 4 malam dan Bali dengan length of stay 3 hari 2 malam.Dimana ketiga daerah tersebut merupakan daerah tujuan wisata yang dipilih oleh wisatawan Timur Tengah. (Sumber : Pra Survey 2016).

Dari lenght of stay atau lama menginap 2 hari 1 malam, memiliki keterbatasan untuk mengunjungi begitu banyaknya atraksi wisata yang di tawarkan di Kota Bandung. 2 hari 1 malam hanya dapat mengunjungi atraksi wisata yang berada di utara Kota Bandung.Hal ini menunjukan bahwa kurangnya pengetahuan wisatawan Timur Tengah terhadap daya tarik wisata di Bandung. 


\section{National Conference of Creative Industry: Sustainable Tourism Industry for Economic Development}

Universitas Bunda Mulia, Jakarta, 5-6 September 2018

ISSN No:

Berdasarkan survei awal yang dilakukan oleh peniliti menemukan bahwa selama ini mayoritas wisatawan Timur Tengah yang datang ke Bandung mendapatkan informasi dari kerabat dan keluarga yang sudah berkunjung sebelumnya. Informasi dari mulut ke mulut mulai dari akomodasi yang akan digunakan, atraksi wisata yang biasa dikunjungi, hingga restoran yang menyajikan makanan khas Timur Tengah dijadikan sebagai satu-satunya panduan yang secara tidak langsung membentuk pola perjalanan para wisatawan dimana sifat informasinya masih terbatas. Hal ini yang menjadikan potensi pariwisata Kota Bandung tidak tereksplorasi secara utuh.

Hal ini yang kemudian dijadikan fokus oleh peneliti karena perjalanan wisata atau sering disebut tour merupakan suatu perjalanan yang berbeda dengan perjalanan yang lainnya karena memiliki ciri tersendiri dan penuh dengan rangkaian beberapa komponen perjalanan yang diperlukan dalam perjalanan tersebut dan wisatawan dalam melakukan suatu perjalanan wisata dipengaruhi oleh beberapa aspek. pada penelitian ini, peneliti melihat dari aspek motivasi, profil wisatawan dan perilaku wisatawan dengan memperhatikan daya tarik wisatawan, fasilitas pendukung dan aksebilitas, karena menurut Kemenbudpar (2010) yang dimaksud dengan pola perjalan (Travel Pattern) adalah pola perjalanan wisata yang dilakukan melalui identifikasi dari pemetaan potensi daya tarik wisata, fasilitas pendukung dan aksesibilitas menuju suatu lokasi daya tarik wisata sebagai suatu rangkaian perjalanan wisata. Sedangkan, menurut RENSTRA tahun 2015 - 2019:

Pola perjalanan pariwisata adalah struktur, kerangka, dan alur perjalanan wisata dari satu titik destinasi ke titik destinasi lainnya yang saling terkait yang berisi informasi tentang fasilitas, aktivitas, dan pelayanan yang memberikan berbagai pilihan perjalanan wisata bagi industri maupun individu wisatawan untuk mempengaruhi pengambilan keputusan dalam melakukan perjalanan wisata.

Dapat disimpulkan bahwa pentingnya sebuah pola perjalanan dalam suatu destinasi agar terciptanya diversifikasi atau penganekaragaman produk destinasi pariwisata.Dengan adanya pengembangan pola perjalanan maka potensi daya tarik wisata, fasilitas pendukung dan aksesibilitas dapat terpantau atau terkontrol dengan baik oleh stakeholder baik pemerintah maupun industri pariwisata.

Atas dasar kondisi tersebut peneliti merasa perlu untuk membuat pola perjalanan wisatawan Timur Tengah di Bandung yang lebih terpadu agar lebih memaksimalkan potensi pariwisata yang ada di Kota Bandung sehinga dapat mengoptimalkan keuntungan usaha pariwisata khususnya dan untuk meningkatan pendapatan daerah pada umumnya.

Pada saat ini sudah banyak penelitian yang mengkaji tentang wisatawan Timur Tengah. Seperti; Ibrahim, dkk, 2009 yang membahas tentang "Travelling Pattern and Preferences of the Arab Tourist in Malaysian Hotels", Ariffin dan Hasim, 2009 yang meneliti tentang "Marketing Malaysia to the Middle East Tourist ; Toward A preferred Inter-regional Destinations", Zin, dkk. 2013 yang fokus terhadap "The Potential of Arabic as a Tourism Language in Malaysia"., Hazbun ditahun 2006 meneliti "Explainning the Arab Middle East Tourism Paradox", Kovjanic, ditahun 


\section{National Conference of Creative Industry: Sustainable Tourism Industry for Economic Development}

Universitas Bunda Mulia, Jakarta, 5-6 September 2018

ISSN No:

2014 "Islamic Tourism as a Factor of the Middle East Regional Development". Sedangkan di Indonesia sendiri sampai saat ini belum familiar dan belum adanya penelitian tentang pola perjalanan khusus untuk wisatawan Timur Tengah.

\section{TINJAUAN PUSTAKA}

$\mathrm{Bab}$ ini membahas teori - teori tentang pola perjalanan wisata yang terdiri dari daya tarik, fasilitas, aksesibilitas, profil wisatawan dan motivasi pola pergerakan wisatawan.

\subsection{Daya Tarik Wisata}

Bagian ini akan menjelaskan tentang daya tarik wisata yang merupakan suatu daya pikat yang dapat memberikan rangsangan kepada seseorang untuk melakukan suatu perjalanan. Menurut UU No 10 Tahun 2009 "daya tarik wisata adalah segala sesuatu yang memiliki keunikan, keindahan, dan nilai yang berupa keanekaragaman kekayaan alam, budaya, dan hasil buatan manusia yang menjadi sasaran atau tujuan kunjungan wisatawan". Dalam daya tarik wisata harus memiliki nilai sehingga layak untuk di jual, karena daya tarik wisata merupakan salah satu unsur dalam produk pariwisata yang harus dapat perhatian khusus dari berbagai stakeholder guna dapat menunjang perkembangan pariwisata.

Menurut Yoeti (1985) menjelaskan bahwa ada tiga kriteria yang menentukan suatu daya tarik wisata dapat diminati oleh wisatawan, yaitu "Something To See, Something To Do dan Something To Buy".

"Something to see" yaitu daya tarik wisata tersebut harus memiliki sesuatu yang dapat di nikmati, dilihat atau dijadikan sebuah tontonan oleh para wisatawan. Dengan begitu daya tarik wisata harus memiliki suatu keunikan atau daya tarik yang khusus yang mampu memberikan minat kepada wisatawan untuk berkunjung.

"Something to do" merupakan suatu upaya yang dilakukan oleh daya tarik wisata tersebut agar wisatawan yang berkunjung dapat melakukan sesuatu yang berguna untuk memuaskan wisatawan, memberikan perasaan senang, bahagia, relaks dengan disediakannya fasilitas rekreasi baik arena bermain maupun tempat makan. Sedangkan "something to buy" menurut Yoeti yaitu fasilitas belanja untuk wisatawan berbelanja atau membeli buah tangan khas daerah tersebut, sehingga bisa dijadikan cinderamata yang unik dan menarik bagi para wisatawan.

Menurut Collier (2004:21) unsur- unsur yang dapat menarik wisatawan dapat di klasifikasikan menjadi dua jenis atraksi yaitu site attraction dan events. "Site attraction are those where the destination itself provides the inducement for the visit. Site attraction can range from a whole country or region to a city, town, or specific attraction such as a piece o architecture and can be either natural or constructed".

Sumber daya alam atau natural resources attraction yaitu landscape, 


\section{National Conference of Creative Industry: Sustainable Tourism Industry for Economic Development}

Universitas Bunda Mulia, Jakarta, 5-6 September 2018

ISSN No:

pegunungan, pantai, flora dan fauna, hutan, dan iklim. Sedangkan yang dimaksud constructed attraction yaitu suatu kultur dan sejarah dari sebuah bangunan, daerah yang memiliki sejarah atau yang mengandung sejarah tentang suatu agama, cara hidup seseorang (termasuk bahasa, agama, tradisi dan makanan) situs - situs arkeolog dan juga beberapa situs yang dibangun dengan tujuan untuk menarik pengunjung seperti taman - taman yang bertema, kebun binatang musium dan panggung hiburan.

Klasifikasi kedua dari sebuah atraksi yaitu Events. "Events draw people to a destination because of what is happening there rather than because of what is there" (Coollier : 2004). Sebuah event dijadikan sebuah strategi untuk mendatangkan pengunjung dengan menambah nilai pada sebuah destinasi, contohnya sepertisport event yaitu PON dan Olimpiade.Festival seperti Banyuwangi Festival dan Festival Pesona Sangihe dan termasuk juga MICE.

Sedangkan berdasarkan Associate Professor Danubius University telah melakukan inventarisasi daya tarik wisata yaitu:

\section{Tabel 2.1}

Inventarisasi daya tarik wisata

\begin{tabular}{|c|l|}
\hline Jenis Daya Tarik & \multicolumn{1}{|c|}{ Kategori } \\
\hline \multirow{2}{*}{ Kultural } & $\begin{array}{l}\text { Situs dan arkeologi, bangunan dan } \\
\text { monumen sejarah, tempat tempat } \\
\text { penting yang mengandung nilai sejarah, } \\
\text { museum, lembaga - lembaga } \\
\text { pendidikan dan politik, maupun } \\
\text { lembaga keagamaan }\end{array}$ \\
\hline Tradisi & $\begin{array}{l}\text { Festival nasional, seni dan kerajinan, } \\
\text { musik, cerita rakyat dan kehidupan asli } \\
\text { dari suatu daerah }\end{array}$ \\
\hline Scenic & $\begin{array}{l}\text { Taman nasional, margasatwa, flora dan } \\
\text { fauna, beach resort, mountain resort }\end{array}$ \\
\hline \multirow{2}{*}{ Entertainment } & $\begin{array}{l}\text { Berpartisipasi atau hanya menonton } \\
\text { suatu pertandingan olahraga, zona } \\
\text { hiburan dan taman rekreasi, } \\
\text { oceanarium, bioskop, night life } \\
\text { dancuisine }\end{array}$ \\
\hline Lainnya & $\begin{array}{l}\text { lklim, health resort atau SPA dan } \\
\text { keunikan lainnya yang tidak dimiliki di } \\
\text { tempat lain }\end{array}$ \\
\hline
\end{tabular}

Jika dilihat dari beberapa definisi tersebut, peneliti menyimpulkan bahwa daya tarik wisata yaitu segala sesuatu yang memiliki daya pikat karena suatu keunikan dan keanekaragaman yang dimiliki yang dapat di kelompokkan menjadi beberapa pengelompokkan daya tarik wisata, yaitu:

1. Daya tarik wisata Alam

Suatu tempat yang menarik untuk dikunjungi karena sumber daya alam yang 


\section{National Conference of Creative Industry: Sustainable Tourism Industry for Economic Development}

Universitas Bunda Mulia, Jakarta, 5-6 September 2018

ISSN No:

dimiliki , yang biasanya masih alami dan di lestarikan kealamiahannya agar tidak terganggu dan terkontaminasi.

The International Economic Society (TIES) (1990) mengatakan bahwa "ecotourism is responsible travel to natural areas which conserved the environment and improves the welfare of local people", wisata alam merupakan usaha pemanfaatan sumber daya alam dan tata lingkungannya yang telah di tetapkan sebagai obyek dan daya tarik wisata untuk dijadikan sasaran wisata.Contoh dari daya tarik wisata alam yaitu;

a. Hutan, dengan aktifitas yang dilakukan seperti:berkemah, mendaki gunung, menikmati keindahan alam. Melakukan pengamatan kehidupan satwa liar (fauna), mengamati tumbuhan yang memiliki keunuikan (flora), tracking dan lintas alam atau jelajah hutan.

b. Bahari atau laut, dengan aktifitas yang dilakukan seperti: mendengar deburan ombak, bersampan, diving atau menyelam, berselancar, bersepeda air, swimming, berjemur, maupun volley pantai.

c. Gua alam, yang bisa dinikmati keunikannya, kelangkaan, keaslian dan keutuhan tata lingkungannya.

d. Iklim atau cuaca, pantai, taman laut, kawah gunung api, air terjun, wisata agro (pertanian dan perkebunan).

e. Bentangan alam (landscape).

2. Daya tarik wisata Budaya

Pariwisata budaya merupakan salah satu produk pariwisata yang disebabkan adanya daya tarik dari seni budaya suatu daerah.Menurut James J. Spillane (2003) bahwa produk pariwisata budaya memiliki segmen pasar khusus yaitu para "knowledge workers".

"Knowledge worker" dalam istilah kepariwisataanya disebut sebagai "mature tourist" atau wisatawan yang berpengalaman dimana mereka melakukan suatu perjalanan tidak hanya bersifat recreational tetapi lebih cenderung kepada motivasi untuk mencari pengalaman dengan terlibat langsung dengan aktivitas aktivitas masyarakat setempat yang memiliki tradisi serta budaya yang berbeda.

Selain dari pada itu, pariwisata budaya menurut Organisasi Pariwisata Dunia (WTO) menjelaskan bahwa kecenderungan pariwisata budaya saat ini diarahkan kepada oengembangan pariwisata berkelanjutan. Karena dapat memberikan ruang luas kepada masyarakat lokal untuk dapat berpartisipasi dalam sektor kepariwisataan.

Suatu keunikan seni budaya bangsa yang dapat dinikmati oleh para wisatawan yang dapat memberikan manfaat dan dapat memperoleh pengalaman kebudayaan yang berbeda dan dapat memperluas cara pandang atau pandangan hidup seseorang, karena daya tarik wisata budaya dapat dilihat secara kongkrit, setengah kongkrit maupun abstrak.

Contoh wisata budaya yang kongkrit secara aspek material yaitu: arsitektur, peninggalan masa lampau, makanan olahan, dan pakaian adat. Daya tarik wisata budaya yang setengah konkrit yaitu sebuah perilaku seperti; kegiatan ritual perkawinan, upacara-upacara keagamaan atau kematian, seni pertunjukan, dan 


\section{National Conference of Creative Industry: Sustainable Tourism Industry for Economic Development}

Universitas Bunda Mulia, Jakarta, 5-6 September 2018

ISSN No:

keterampilan membuat barang-barang kerajinan. Sedangkan daya tarik wisata budaya yang abstrak seperti: sistem keyakinan, nilai -nilai dan norma - norma.

3. Daya tarik wisata Buatan

Daya traik wisata buatan didesain dan di bangun dengan bertujuan agar dapat menarik wisatawan dan memberikan nilai tambah terhadap pengalaman berwisata, serta dengan adanya daya tarik wisata buata dapat memenuhi kebutuhan yang di butuhkan oleh para wisatawan.

Berikut beberapa contoh dari daya tarik wisata buatan: theme park, taman rekreasi dengan tema tema tertentu, galeri seni dan museum, montain resort.beach resort, health resort atau SPA, kebun binatang (zoo), taman atau pusat hiburan. Shopping center,farm, botanical garden, aquarium atau marine world, event dan exhibition, urban dan country park dan teater.

\subsection{Fasilitas dan Aksesibilitas}

Bagian ini akan menjelaskan tentang fasilitas dan aksesibilitas yang dibutuhkan dalam perencanaan kawasan wisata.

\subsubsection{Fasilitas}

Fasilitas memiliki peran yang pentig walaupun tidak secara langsung menarik atau medatangkan wisatawan untuk berkunjung, namun dengan ketersediaanya fasilitas atau amenitas yang baik dan berkualitas akan menambah nilai pada suatu daya tarik wisata dan memberikan kepuasan kepada pengunjung, karena sebuah fasilitas harus dapat menyediakan kebutuhan dasar yang dibutuhkan oleh wisatawan.

Menurut Collier (2004) fasilitas dapat di bagi menjadi dua kategori yaitu infrastruktur dan superstruktur.

a. Kategori infrastruktur yaitu jalan, listrik, pasokan air bersih, toilet dan pengelolaan limbah.

b. Kategori superstruktur yaitu akomodasi, restoran, fasilitas - fasilitas hiburan, dan kebutuhan yang diperlukan oleh wisatawan seperti; agen perjalanan (travel agent), dan rental mobil.

Kedua hal tersebut saling berkaitan, karena fasilitas superstruktur tidak akan ada tanpa adanya rencana infrastruktur yang bagus dan infrastruktur yang dibangun dengan baik. Kemudahan fasilitas yang terdapat sebuah kawasan wisata bisa dijadikan sebuah daya tarik wisata, contohnya sebuah restoran yang merupakan termasuk kedalam sebuah fasilitas wisata jika lokasinya strategis restoran tersebut bisa dijadikan sebuah daya tarik wisata.

Selain daripada pengelompokan tersebut terdapat pula fasilitas penunjang lainnya yang bersifat spesifik dan disesuaikan dengan kebutuhan perjalanan seperti fasilitas telekomunikasi, fasilitas money changer. Komponen - komponen fasilitas tersebut tidak terlepas dari adanya komponen prasarana atau infrastruktur, sebagai contoh yaitu fasilitas transportasi akan tersedia apabila prasarana jalan sudah ada atau tersedia. Fasilitas telekomunikasi dapat disediakan apabila prasarana jaringan di destinasi wisata tersebut tersedia.

Hall and Page (2002) mengkategorikan beberapa komponen fasilitas pendukung wisatwan, yang dijadikan fokus untuk memenuhi kebutuhan wisatawan pada penelitian ini yaitu: akomodasi, restoran, shopping centre, dan kondisi 


\section{National Conference of Creative Industry: Sustainable Tourism Industry for Economic Development}

Universitas Bunda Mulia, Jakarta, 5-6 September 2018

ISSN No:

elemenlainnya.

Akomodasi merupakan komponen utama yang harus diperhatikan dalam sebuah perjalanan, karena ketersediaan akomodasi dalam suatu kawasan wisata dapat mewakili citra dari daya tarik wisata tersebut dan ketersediaanya akomodasi dapat memberikan kesempatan kepada wisatawan untuk tinggal lebih lama sehingga memiliki kesempatan untuk lebih menikmati daya tarik wisata di daerah tersebut. Menurut Surat Keputusan Menteri Pariwisata Pos dan Telekomunikasi No.37/PW.304/MPT/86 yang dimaksud dengan Akomodasi adalah wahana yang menyediakan pelayanan jasa penginapan yang dilengkapi dengan pelayanan makan dan minum serta jasa lainnya, seperti: Hotel, Losmen, Bungalow.

Komponen berikutnya dari fasilitas agar memenuhi kebutuhan wisatawan yaitu restoran. Menurut Atmodjo (2005) restoran adalah suatu tempat atau bangunan yang diorganisir secara komersil, yang menyelenggarakan pelayanan dengan baik kepada semua konsumennya baik berupa makanan maupun minuman. Tujuan operasional restoran adalah untuk mencari keuntungan dan membuat puas para konsumennya. Menurutnya Atmodjo restoran terbagi kedalam beberapa kategori, yaitu:

a. A La Carte Restaurant, merupakan restoran yang telah mendapatkan ijin penuh untuk menjual makanan,lengkap dengan banyak variasi. Dan konsumen diberi kebebasan untuk memilih sendiri makanan yang dikehendaki.

b. Cafetaria atau Cafe, merupakan restoran kecil yang mengutamakan penjualan kue, roti, kopi dan teh. Pilihan makanan terbatas dan tidak menjual minuman beralkohol.

c. Snack Bar atau Milk Bar, merupakan restoran dengan tempat yang tidak terlalu luas yang sifatnya tidak resmi dengan pelayanan yang cepat, konsumen mengumpulkan makanan mereka diatas baki yang diambil dari atas counter (meja panjang yang membatasi dua ruangan) kemudian membawanya sendiri ke meja makan. Konsumen bebas memilih makanan yang disukai, disini lebih dikenal dengan nama restoran cepat saji (fast food). Makanan yang tersedia umumnya hamburger, roti isi, kentang goreng, ayam goreng, nasi, dan mie.

d. Specialty Restoran, merupakan restoran yang suasana dan dekorasi seluruhnya disesuaikan dengan tipe khas makanan yang disajikan atau temanya. Restoran-restoran semacam ini menyediakan masakan Eropa, China, Jepang, India, Timur Tengah dan sebagainya.

Shopping atau kegiatan berbelanja merupakan kebutuhan wisatawan yang sangat penting yang harus diperhatikan oleh suatu daerah wisata, karena berbelanjan atau shopping dapat mendorong wisatawan untuk berbelanja dan membeli marchandise maupun produk produk yang ditawarkan.

Menurut Newby dalam buku Timothy (2005), shopping atau berbelanja jika dilihat dari motivasi wisatawan terbagi menjadi dua, yaitu berbelanja merupakan suatu hal yang melelahkan dan dilakukan untuk memenuhi kebutuhan pribadi atau berbelanja merupakan suatu hal yang menyenangkan, menghibur, santai karena untuk memenuhi keinginan para wisatawan yang memiliki pandangan hidup yang 


\section{National Conference of Creative Industry: Sustainable Tourism Industry for Economic Development}

Universitas Bunda Mulia, Jakarta, 5-6 September 2018

ISSN No:

hedonis atau yang disebut juga sebagai recreational shoppers.

Recreational shopper adalah wisatawan yang menikmati berbelanja di waktu luang, wisatawan memiliki kemauan atau gagasan apa yang akan mereka beli dan tanpa memeperdulikan jarak perjalanan yang akan ditempuh. Menurut Timothy (2005)recreational shopperakan lebih spontan, menghabiskan waktu luangnya untuk berbelanja dan akan melanjutkan berbelanja setelah melakukan pembelian. Maka dari itu, untuk membidik pasar recretional shopper, fasilitas dan amenitas pada sebuah pusat perbelanjaan harus betul - betul diperhatikan karena itu merupakan salah satu pemicu para recreational shopper dalam pengambilan keputusan untuk kembali.

Kondisional element yang menjadi faktor pendukung yang penting pada fasilitas untuk meningkatkan nilai tambah tambah untuk para wisatawan, seperti : rumah ibadah, money changer, agen perjalanan (travel agent), rent car, ATM atau Bank dan SPBU.

\subsubsection{Aksesibilitas}

Aksesibilitas merupakan suatu ukuran potensial atau kemudahan orang untuk mencapai tujuan dalam suatu perjalanan.Menurut Yoeti (1997) bahwa aksesibilitas adalah kemudahan dalam mencapai daerah tujuan wisata baik secara jarak gografis atau kecepatan teknis, serta tersedianya sarana transportasi ketempat tujuan tersebut.Sedangkan menurut Collier (2004) "just as the attractions and amenities at a destination will affect its appeal to visitors, so will that destination's accessibility". Namun ada beberapa daya tarik wisata yang menarik minat wisatawan karena aksesnya yang sulit, keunikan akan suatu daerah yang terisolasi walau pun tidak memiliki akses yang baik namun dapat dijadikan daya tarik tersendiri bagi wisatawan tersebut. Pentingnya faktor aksesibilitas dalam sebuah perjalanan pariwisata, tidak dapat dipisahkan dari unit transportasi yang tersedia dan digunakan oleh wisatawan.

"Transportasi memiliki peran yang vital dalam kegiatan bisnis pariwisata dan perjalanan wisata dimana sebagai sarana pergerakan wisatawan dari satu daerah ke daerah lainnya, dari satu destinasi ke destinasi lainnya, dari satu daya tarik wisata ke daya tarik wisata lainnya" (Swarbrooke, 2001). Perkembangan pariwisata dalam negeri menuntut perkembangan bidang perjalanan pula.Pertumbuhan dan pengembangan pariwisata yang terus-menerus harus disertai dengan peningkatan kualitas destinasi dengan menciptakan tuntutan yang lebih baik di dalam transportasi.

Transportasi memberi dampak pada pertumbuhan pariwisata di berbagai negara. Fasilitas transportasi yang tersedia dengan cukup, aman, terjangkau menuju objek wisata akan dapat memicu peningkatan jumlah wisatawan yang akan berkunjung dan sebaliknya pengembangan objek wisata akan dapat merangsang pengembangan transportasi. Hubungan antara pariwisata dan transportasi terutama sangat dipengaruhi oleh dua elemen yaitu: kemudahan mengakses tujuan (convenient access),kualitas layanan transportasi harus memenuhi harapan pengguna seperti tingkat keamanan, kenyamanan, frekuensi, efisiensi dan keandalan. Hall (1999) membedakan empat peran transportasi: 


\section{National Conference of Creative Industry: Sustainable Tourism Industry for Economic Development}

Universitas Bunda Mulia, Jakarta, 5-6 September 2018

ISSN No:

a. Angkutan untuk sampai ke lokasi tujuan. Moda transportasi yang digunakan terbagi kedalam tiga jenis yaitu udara, air dan darat.

b. Angkutan memastikan mobilitas di dalam tujuan. Moda transportasi yang digunakan meliputi hired - private car, bus dengan reservasi, bus umum, angkutan umum, taxi dan ojek.

c. Mobilitas di dalam pertunjukan wisata. Moda transportasi yang digunakan biasanya dalam bentuk wara-wiri, ojek, sepeda sewaan.

d. Perjalanan sepanjang jalur daerah rekreasi. Moda transportasi yang biasa digunakan adalah hired - private car, angkutan antar kota, ojek, motor sewaan, sepeda sewaan, becak.

Selain aksesibilitas dilihat dari kemudahan dan transportasinya, aksesibilitas lainnya yang mempunyai pengaruh yang cukup penting dalam pariwisata yaitu dilihat dari kualitas jalan yang tersedia untuk menuju daya tarik wisata tersebut dan waktu mengemudi yang harus di tempuh untuk sampai ke daerah wisata tersebut.

\subsection{Profil Wisatawan}

Bagian ini akan menjelaskan tentang profil wisatawan dilihat dari sosiodemografi wisatawan dan Psikografi wisatawan serta tipologi wisatawan.

\subsubsection{Sosio-demografi Wisatawan}

Sosio-demografi berasal dari dua kata, yaitu sosial dan demografi.Sosial adalah salah satu komponen variabel non-demografi, seperti pendidikan, pekerjaan, daerah asal dan adanya waktu senggang. Sedangkan demografi adalah suatu ilmu yang mempelajari penduduk di suatu wilayah terutama mengenai jumlah, struktur (usia, jenis kelamin, agama), dan proses perubahannya (kelahiran, kematian, perkawinan, dan lain lain) (Desa, 2008).

Di dalam manajemen pariwisata, sosio-demografi menjadi salah satu faktor yang mempengaruhi perilaku wisatawan. Orang dengan tingkat pendapatan dan mobilitas yang lebih tinggi secara umum memiliki permintaan wisata yang lebih tinggi juga, dan lebih banyak melakukan kegiatan wisata.Beberapa studi telah menunjukkan adanya hubungan tersebut (Schuster, Merriman dalam Richards, 1996).

Berdasarkan aspek geografi, memahami wilayah asal kedatangan merupakan aspek penting dalam memahami karakteristik wisatawan karena hal tersebut berkaitan dengan kebudayaan, nilai, sikap, kepercayaan, dan sistem (Ismayanti, 2010:66).

Tingkat dan pola perjalanan wisata dapat dipengaruhi oleh karakteristik sosial dan demografi penduduk. Perbedaan jenis kelamin, status perkawainan, jumlah anggota keluarga, tingkat pendidikan dan pekerjaan, serta pendapatan seseorang akan membawa perbedaan pada kegiatan wisata yang dilakukannya.

Menurut Ismayati (2010:53) klasifikasi wisatawan di bedakan berdasarkan demografi,yaitu berdasarkan usia, latar belakang pendidikan, pendapatan, jenis kelamin, dan siklus keluarga.

Variabel - variabel yang ada di dalam karakteristik sosio-demografi merupakan faktor yang penting untuk di teliti karena dapat mempengaruhi perilaku dan permintaan berwisata. Maka pada penelitian ini sosio-demografi wisatawan Timur 


\section{National Conference of Creative Industry: Sustainable Tourism Industry for Economic Development}

Universitas Bunda Mulia, Jakarta, 5-6 September 2018

ISSN No:

Tengah di klasifikasikan berdasarkan Usia, Latar belakang pendidikan, Pendapatan dan jenis kelamin.

a. Usia

(1) Kelompok kanak- kanak atau babyboomlet atau generasi $\mathrm{X}$

Kelompok ini berusia 0 sampai 9 tahun terdiri atas berbagai kategori, yaitu bayi atau bawah satu tahun, batita atau dibawah lima tahun dan anak - anak atau enam sampai sembilan tahun. Kelompok ini tidak memiliki daya beli, namun dia memiliki pengaruh terhadap orang tua dalam memilih tempat wisata.

(2) Kelompok remaja (babybuster)

Berusia antara 9-16 tahun dan sering dianggap usia tanggun karena ia ingin dianggap dewasa tetapi secara mental masih kekanak-kanakan. Wisatawan dari kelompok ini cenderung melakukan perjalanan group. Anggotanya memiliki minat dan hobi yang sama.

(3) Kelompok anak muda (late babyboomer)

Anak muda pada kelompok ini berusia diatas 17 tahun.Ia lebih dewasa dibandingkan dengan kelompok remaja dan sudah mulai lebih banyak berpikir dengan logika daripada emosi.Kelompok ini aktif dan enerjik sehingga pilihan kegiatan wisata harus bisa menyalurkan energi dan kemampuannya.

(4) Kelompok Dewasa

Wisatawan pada kelompok dewasa berusia sekitar 24 hingga 50 tahun. Dia sudah memiliki pekerjaan tetap dan masuk dalam usia produktif sehingga kesempatan wisata merupakan hal yang langka dan ditunggu. Perencanaan perjalanan harus dilakukan karena berkaitan dengan waktu cuti dan pendanaan.

(5) Kelompok Setengah Baya atau Worldwar Babies

Wisatawan setengah baya adalah wisatawan dewasa yang sangat mapan dan memiliki ciri-ciri dia mempunyai pedapatan yang cukup tinggi namun waktu wisata yang terbatas, umumnya masih memiliki kondisi fisik yang baik sehingga mampu melakukan kegiatan yang berpetualang, dalam pemilihan fasilitas dan pelayanan ia mempunyai referensi tersendiri, minat terhadap alam dan budaya, dalam pengambilan keputusan untuk liburan sangat banyak faktor yang perlu di pertimbangkan.

(6) Kelompok Senior

Istilah senior menggambarkan mereka yang ada di kategori berumur 50 tahun keatas. Beberapa diantaranya masih aktif bekerja atau sering disebut lanjut usia tetapi sebagian besar sudah memasuki masa pensiun. Wisatawan ini umumnya kurang menyukai kegiatan diluar ruangan dan lebih memilih berkegiatan di dalam ruangan.

b. Latar Belakang Pendidikan 


\section{National Conference of Creative Industry: Sustainable Tourism Industry for Economic Development}

Universitas Bunda Mulia, Jakarta, 5-6 September 2018

ISSN No:

Latar belakang pendidikan wisatawan Timur Tengah tergolong Wisatawan yang berpendidikan tinggi yang cenderung memiliki minat untuk mendalami sesuatu, ingin lebih bersosialisasi dengan penduduk setempat, dan lebih fleksibel. Walaupun mereka memiliki keterbatasan dari segi bahasa yang digunakan, karena sangat sedikit dari mereka yang dapat berbahasa Inggris maupun Indonesia. Yang mencerminkan mereka memiliki latar belakang pendidikan yang tinggi juga dapat dilihat dari cara mereka melakukan pemesanan akomodasi seperti di Sensa Hotel, para wisatawan Timur Tengah banyak menggunakan jasa online.

c. Pendapatan

Pendapatan secara umum berkaitan dengan pendidikan, pekerjaan dan usia. Wisatawan yang berpenghasilan tinggi, cenderung memiliki tingkat pendidikan yang tinggi dengan jenis pekerjaan yang tetap dan usia tertentu. Pengaruh pendapatan terhadap pola perjalanan sangat erat terutama berkaitan dengan waktu yang tersedia untuk berwisata.

d. Jenis kelamin

Karakter wisatawan dari sudut pandang gender atau jenis kelamin merupakan hal yang cukup penting untuk wisatawan asal Timur Tengah. Kegiatan wisata didominasi oleh kaum pria, sedangkan seorang perempuan dalam berpergian harus didampingi oleh mukhrim nya.

\subsubsection{Karakteristik Psikografi}

Menurut Engel, dkk (1994) "Psikografis merupakan teknik yang dilakukan oleh peneliti konsumen sebagai ukuran operasional dari gaya hidup". Sedangkan menurut Mowen dan Minor, psikografis dipergunakan untuk mengukur gaya hidup konsumen dengan menganalisa aktivitas minat dan opini.

Psikografis analisis biasanya dipakai untuk melihat segmentasi pasar. Menurut Sumarwan (2004), "analisis psikografis juga diartikan sebagai suatu riset konsumen yang menggambarkan segmen konsumen dalam hal kehidupan mereka, pekerjaan dan aktifitas lainnya".

Berdasarkan definisi tersebut maka dapat disimpulkan bahwa Selain dilihat dari geografis dan demografi, untuk melihat suatu segmentasi pasar dan profil wisatawan perlu juga dilihat dari faktor psikografis yang akan lebih menjelaskan tentang kelas sosial, personalitas dan gaya hidup.

Kelas sosial menurut para ahli yang tertuang dalam buku pengantar Sosiologi, yang ditulis oleh Sunarto menjelaskan bahwa menurut Marx dan Weber, kelas sosial dikaitkan dengan posisi seseorang dalam masyarakat berdasarkan kriteria ekonomi, sedangkan menurut Bernard Barber mendefinisikan kelas sosial tidak hanya berlaku untuk setiap individu namun kelas sosial juga akan berlaku pada suatu group atau sebuah keluarga. Pada penelitian ini, kelas sosial pada wisatawan Timur Tengah dilihat dari segi ekonomi, pekerjaan dan pendidikan baik secara individu maupun keluarga. 


\section{National Conference of Creative Industry: Sustainable Tourism Industry for Economic Development}

Universitas Bunda Mulia, Jakarta, 5-6 September 2018

ISSN No:

Berdasarkan status ekonomi, Aristoteles membagi kelas menjadi beberapa kelas atau golongan, yaitu:

a. Kelas sangat kaya, yaitu kecil dari suatu masyarakat yang menjadi pengusaha, tuan tanah maupun bangsawan.

b. Kelas kaya, kelas ini merupakan kelas yang cukup banyak di tengah - tengah masyarakat, bagian dari kelas ini diantaranya adalah pedagang.

c. Kelas miskin, kelas ini merupakan kelas terbanyak yang ada di masyarakat, karena mereka kebanyakan adalah rakyat biasa.

Personalitas atau kepribadian merupakan sesuatu yang unik dan khas yang ada di setiap individu. Setiap indiviud memiliki ciri dan karakteristik yang bebeda bedayang dapat mempengaruhi perilaku dari setiap individu tersebut. Menurut Churchill Jr \& Gilbert A (2005) "personalitas atau kepribadian itu lebih mengacu kepada pola-pola normal dari perilaku yang ditunjukan oleh setiap individu, seperti atribut-atribut, sifat-sifat dan kebiasaan yang membedakan individu dengan individu lainnya".

Ada beberapa faktor yang dapat mempengaruhi personalitas, seperti yang diungkapkan oleh Pervin dan John (2001) bahwa personalitas atau kepribadian dapat dipengaruhi oleh dua faktor, yaitu faktor genetik dan faktor lingkungan.Dimana faktor genetik adal faktor yang dihasilkan oleh keturunan yang bersifat kekal dan diwariskan secara turun temurun dari satu sel ke sel lainnya. Sedangkan faktor lingkungan yaitu factor - faktor kepribadian karena adanya pengalaman - pengalaman dari orang lain, faktor ini meliputi budaya suatu kelas sosial, keluarga, dan situasi.

Faktor psikografis ketiga yaitu berkaitan dengan gaya hidup. Pengertiaan gaya hidup menurut Minor dan Mowen (2002), gaya hidup menunjukkan bagaimana orang hidup, bagaimana membelanjakan uangnya, dan bagaimana mengalokasikan waktu. Gaya hidup menurut WHO 1998 yaitu "life style is a way of living based on identifiable patterns of behaviour which are determined by the interplay between an individual's personal characteristics, social interaction, and socioeconomic and environmental living condition". Gaya hidup menurut Kotler (2002) adalah pola hidup seseorang di dunia yang di ekspresikan dalam aktivitas, minat, dan opininya. Sedangkan menurut Plummer (1983) menyatakan bahwa gaya hidup adalah cara hidup individu yang diidentifikasi oleh bagaimana orang menghabiskan waktu mereka (aktivitas), apa yang mereka anggap penting dalam hidupnya (ketertarikan) dan apa yang mereka pikirkan tentang dunia sekitar.

Berdasarkan definisi diatas dapat disimpulkan bahwa, gaya hidup merupakan cara seseorang untuk mengekspresikan diri atau aktualisasi diri, dengan suatu kebiasaan atau hobby dan opini dengan cara yang berbeda yang meunjukkan status dan menyimbolkan kepribadian dari masing masing individu.

\subsubsection{Tipologi Wisatawan}

Untuk mengetahui tipologi (jenis atau macam) wisatawan, Plog (1974), mencetuskan sebuah teori yang menghubungkan sebuah popularitas dari sebuah destinasi dengan sesuatu yang melekat pada diri seorang wisatawan. Menurut Plog, S wisatawan dapat diklasifikasian menjadi 3 bagian yaitu ; Tipe Allocentric, Tipe Psychocentric dan Tipe Mid - Centric. 


\section{National Conference of Creative Industry: Sustainable Tourism Industry for Economic Development}

Universitas Bunda Mulia, Jakarta, 5-6 September 2018

ISSN No:

Tipe Allocentric adalah seorang wisatawan yang selalu ingin mecari pengalaman baru dan memilih aktifitas yang berpetualang. Wisatawan yang memiliki rasa percaya diri yang tinggi sehingga wisatawan tipe ini lebih memilih untuk mengeksplorasi sesuatu yang baru dan yang tidak biasa bahkan sesuatu yang belum diketahui oleh orang lain. Wisatawan tipe allocentric ini sangat menyukai pertemuan dengan orang orang baru, orang - orang yang memiliki budaya yang berbeda dengan budaya nya. Untuk akomodasi wisatawan tipe allocentric pemilihan hotel dan restoran memiliki kriteria sendiri, tidak harus modern atau hotel yang berbintang dan termasuk kedalam hotel chain.Untuk penggunaan travel agent, tipe allocentric ini hanya menggunakan jasanya untuk reservasi yang sifatnya mendasar seperti transportasi dan hotel, untuk itinerary atau paket wisata tipe ini sulit untuk berkomitmen dengan ketepatan jadwal yang terstruktur.mereka akan menjadwalkan perjalanan wisatanya sendiri sesuai dengan keinginannya, serta memilih aktifitas dan atraksi wisata sesuai dengan yang ia inginkan.

Tipe Psychocentric adalah seorang wisatawan yang lebih konservatif, dan tidak menyukai aktifitas berpetualang. Mereka lebih memilih untuk sesuatu yang familiar karena tujuan dari perjalanan wisatawan tipe Psychocentric ini untuk bersantai. Tipe wisatwan ini merupakan wisatawan yang well-planned dinama segala segala sesuatunya sudah jelas dan terencana, contoh seperti jenis makanan yang akan dikonsumsi serta aktifitas - aktifitas yang akan dilakukan. Tipe Psychocentric ini lebih memilih tujuan wisata yang memiliki kesamaan, bermalam di hotel dan makan di restoran yang familiar.ketika menggunakan jasa travel untuk paket wisata yang menjadi fokus oleh wisatawan tipe ini yang berkenaan dengan jadwal atau itinerary, karena harus sesuai dengan ekspektasi wisatawan. Selain itu, wisatawan ini juga akan menitik beratkan pada keselamatan dan keamanannya selama melakukan perjalanan wisata.

Tipe Mid - Centric adalah tipe wisatawan yang berada di tengah - tengah antara tipe allocentric dan tipe psychocentric dimana wisatawan ini bukan wisatawan yang menyukai petualangan namun mereka juga dapat menerima sesuatu yang baru.

Tipologi wisatwan ini menjadi dasar untuk perencanaan pola perjalanan wisatam, maka sangat penting untuk diketahui agar mampu mengembangkan objek wisata yang sesuai dengan segmentasi pasar.

\subsection{Motivasi Pola Pergerakan Wisatawan}

Karakter demografi seseorang akan berpengaruh terhadap motivasi wisatawan dalam melakukan suatu perjalanan wisata. Motivasi adalah suatu keinginan yang mendorong seseorang untuk mengambil suatu tindakan, bekerja keras untuk mecapai suatu tujuan dan memenuhi setiap kebutuhan. Banyaknya teori dan pembahasan tentang teori motivasi, namun pada penelitian ini akan membahas pengertian teori motivasi dari Maslow yaitu Hierarchy of human needs. Menurut Maslow (1971) seseorang akan termotivasi oleh lima kebutuhan dasar, yaitu:

a. Physiological needs

Ini merupakan kebutuhan suatu manusia untuk mempertahankan diridan memperpanjang hidup. Ini termasuk kebutuhan mendasar yang sangat 


\section{National Conference of Creative Industry: Sustainable Tourism Industry for Economic Development}

Universitas Bunda Mulia, Jakarta, 5-6 September 2018

ISSN No:

dibutuhkan seperti:oksigen, air, baju, makanan, tempat tinggal, mobilitas dan fungsi - fungsi psikologis lainnya.

b. Safety needs

Kebutuhan akan keselamatan dan keamanan dari bahaya, untuk memenuhi kebutuhan rasa aman untuk berwisata, para wisatawan cendurung melakukan pemesanan dan pengaturan perjalanan melalui lembaga yang sudah terdaftar di Asosiasi maupun lembaga pemerintahan. Selain itu contoh dari kebutuhan akan keselamatan dan keamanan, seperti: keamanan, tempat berlindung, hukum dan kesehatan.

c. Social needs

Kebutuhan sosial ini adalah kebutuhan untuk dimiliki atau belingin, cinta, kasih sayang serta hubungan dengan teman dan keluarga. Kebutuhan ini dapat terpenuhi dengan cara hubungan dengan orang lain. Dengan memiliki hubungan yang baik dengan sesama, secara tidak langsung akan mendapatkan kepuasan dasar fisiologis dan rasa aman.

d. Esteem needs

Setelah kebutuhan yang lebih mendasar telah terpuaskan, selanjutkan akan adanya kebutuhan suatu harga diri pada setiap individu. Kebutuhan esteem ini biasanya ada di posisi seseorang yang lebih tinggi yang bertindak untuk mendorong nilai harga diri atau rasa bangga dalam suatu kelompok. Contoh dari kebutuhan harga diri ini yaitu: rasa percaya diri, rada hormat, pengakuan dan prestasi.

e. Self-actualization

Kebutuhan akan aktualisasi diri ini merupakan tingkat tertinggi dari Hierarki Maslow. Tingkat kebutuhan yang terkait dengan potensi yang ada di dalam diri seseorang dan bagaimana mewujudkan potensi tersebut.

Menurut MacInctosh \& Goeldner (1990), terdapat empat kategori motivasi yang dapat menjelaskan wisatawan dalam melakukan perjalanan:

a. Physical Motivations

Motivasi fisikal berkaitan dengan orang-orang yang melakukan perjalanan dengan tujuan untuk mengembalikan keadaan fisik yang sudah lelah karena bekerja terus, perlu istirahat dan bersantai, melakukan kegiatan olahraga, agar sekembali dari perjalanan wisata bisa bergairah kembali waktu masuk kerja. Contohnya: untuk relaksasi, kesehatan, kenyamanan, berpartisipasi dalam kegiatan olahraga, dan bersantai.

b. Cultural Motivations

Orang tergerak hatinya untuk melakukan perjalanan wisata disebabkan ingin melihat dan menyaksikan tingkat kemajuan kebudayaan suatu bangsa, baik di masa lalu maupun apa yang sudah dicapai masa sekarang. Terdapat keinginan melihat adat istiadat dan kebiasaan hidupnya yang berbeda dengan bangsalainnya.

c. Interpersonal Motivations

Disini,orang - orang ingin melakukan perjalanan wisata karena adanya dorongan untuk mengunjungi keluarga yang sudah lama tidak bertemu atau 


\section{National Conference of Creative Industry: Sustainable Tourism Industry for Economic Development}

Universitas Bunda Mulia, Jakarta, 5-6 September 2018

ISSN No:

ingin mencari teman yang sudah lama tidak bertemu.

d. Status dan Prestige Motivations

Ada orang-orang tertentu yang ingin memperlihatkan kepada orang lain tentang siapa dia diantara orang banyak yang ada di lingkungannya. Dengan melakukan perjalanan wisata seakan-akan statusnya lebih dari orang lain, atau semakin banyak ia berpergian ke luar negeri prestige-nya akan naik. Kategori ini termasuk dalam pengembangan diri seseorang dalam kaitannya dengan hobi dan pendidikan yang diminati.

Sedangkan, pola pergerakan wisatawan (tourist movement pattern) merupakan suatu pergerakan wisatawan dari satu atraksi ke atraksi lainnya atau dari suatu destinasi ke destinasi lainnya. Seperti yang dikatakan oleh Lau \& McKercher (2006) "Tourist movements are the spatial changes of activity locations of tourists".

Unsur - unsur perjalanan wisata yaitu seperti fasilitas umum dan fasilitas wisata, aktivitas di atraksi wisata dan aksesibilitas. Dengan memahami kebutuhan wisatawan dan pola aktivitas mereka di sebuah destinasi atau daerah tujuan wisata dapat membantu dalam mendisain kebijakan, pengelolaan pengunjung yang lebih baik dan pengembangan produk - produk pariwisata baru (Lau and McKarcher, 2006).

Pola pergerakan wisatawan dapat dipengaruhi oleh berbagai macam faktor. Faktor - faktor tersebut dapat dibagi kedalam tiga aspek utama seperti yang telah diidentifikasi oleh Lau dan McKercher (2006) “... they are: human 'push' factors (tourist role, travel party, personal motivations, prior visits, etc), physical 'pull' factors (destination, geomorphology and configuration) and time factor (length of stay in destination, total trip duration)".

Keputusan seseorang untuk melakukan pergerakan dan perjalanan wisata dipengaruhi oleh kuatnya dua hal tersebut yaitu faktor - faktor pendorong (push factor) dan faktor - faktor penarik (pull factor).kedua faktor ini merupakan faktor internal dan eksternal yang memotivasi wisatawan untuk mengambil keputusan.

a. Human "push" factors

Push factor menurut, Dann (1977) "these are internal or intangible factor that lead to the formation of travel desire among potential tourists". faktor faktor pada setiap manusia yang berhubungan dengan individualitas, personalitas, dan karakter wisatawan. "push factor" harus dapat memberikan rangsangan dan motivasi pada setiap wisatawan untuk melakukan perjalanan wisata, karena sebagian besar push faktor ada di dalam keinginan setiap masing masing individu yang ingin di wujudkan.

Pada dasarnya perbedaan karakter pada wisatawan secara tidak langsung membentuk berbagai perbedaan mereka dalam membuat keputusan rencana perjalanan (travel itinerary) dan pola - pola pergerakan (movement patterns).

Tabel 2.2

Model push factor dalam motivasi wisatawan

\begin{tabular}{|c|c|}
\hline Faktor Psikologi & $\begin{array}{l}\text { Faktor socio ekonomi dan sosio } \\
\text { demografi }\end{array}$ \\
\hline $\begin{array}{ll}\text { - } & \text { Escape atau melarikan diri } \\
\text { - } & \text { Istirahat dan Relaksasi }\end{array}$ & $\begin{array}{l}\text { - Usia, Jenis kelamin, pendapatan. } \\
\text { Latar belakang pendidikan, etnik }\end{array}$ \\
\hline
\end{tabular}


National Conference of Creative Industry: Sustainable Tourism Industry for Economic Development

Universitas Bunda Mulia, Jakarta, 5-6 September 2018

ISSN No:

\begin{tabular}{|c|c|}
\hline $\begin{array}{ll}\text { - } & \text { Kesehatan dan Kebugaran } \\
\text { - } & \text { Prestige } \\
\text { - } & \text { Petualangan } \\
\text { - } & \text { Interaksi Sosial }\end{array}$ & suatu group. \\
\hline
\end{tabular}

(Sumber: Dann, 1977)

Dari tabel diatas dapat dilihat bahwa adanya faktor pendorong pada setiap wisatawan untuk melakukan suatu perjalanan namun belum jelas daerah mana dan daya tarik seperti apa yang sesuai dengan motivasinya. Faktor psikologi seperti escape atau melarikan diri dari suatu kejenuhan aktivitas sehari - hari dan ingin melepaskan diri dari lingkungan yang dirasa menjemukan dengan beristirahat untuk melakukan relaksasi guna mengembalikan kesegara. Selain itu faktor kesehatan dan kebugaran dijadikan sebagai faktor pendorong karena ada suatu daya tarik atau atraksi wisata yang memang di ciptakan untuk kesehatan.

Faktor pendorong prestise, merupakan suatu faktor pendorong yang bertujuan untuk menunjukan gengsi, biasanya destinasi yang dituju merupakan destinasi - destinasi yang berkelas dan memiliki gaya hidup kelas atas yang mampu mendorong untuk menaikan status dan kelas sosial.

Sedangkan untuk faktor pendorong seperti petualangan memiliki keinginan untuk menemukan sesuatu yang baru dan untuk penemuan diri sendiri atau kepribadian, karena diri sendiri atau kepribadian biasanya bisa ditemukan pada saat menemukan daerah baru atau bertemu dengan orang baru.Dengan adanya faktor pendorong pertualangan dapat memunculkan faktor interaksi sosial, karena faktor interaksi sosial terjadi akibat adanya keinginan dari wisatawan untuk melakukan interaksi sosial dengan masyarakat setempat.Namun untuk faktor sosio ekonomi sudah dibahas terlebih dahulu dalam profil wisatwaan.

b. Physical 'pull' factors

Faktor - faktor ini menjadi salah satu motivasi yang muncul dari luar diri wisatawan (pull factor) yang bersifat tangible atau fisikal.ini merupakan faktor - faktor penarik yang dimiliki oleh daerah tujuan wisata yang dapat menyebabkan wisatawan akan memilih daerah tujuan wisata tersebut guna memenuhi keinginan dan kebutuhannya.

Faktor - faktor fisikal yang mempengaruhi pola pergerakan wisatawan dapat dikelompokkan menjadi 3 aspek umum, yaitu: destination configuration, attractions dan transport network (Lau dan McKercher, 2006).

Destination configuration yaitu lebih kepada aspek kelembagaan pada suatu destinasi, seperti sumber daya manusia, sistem dan kelembagaan yang berupa lembaga pariwisata yang mendukung sebuah destinasi serta lembaga lembaga lainnya yang dapat ikut serta memberikan kenyamanan kepada para wisatawan.

Attraction atau atraksi wisata yang merupakan atribut dari sebuah daerah tujuan wisata yang dapat menarik wisatawan, baik berupa alam dan kebudayaan. Sedangkan yang dimaksud dengan transport network atau aspek 


\section{National Conference of Creative Industry: Sustainable Tourism Industry for Economic Development}

Universitas Bunda Mulia, Jakarta, 5-6 September 2018

ISSN No:

transportasi merupakan suatu akses bagi para wisatwan baik wisatawan domestik maupun mavanegara agar dengan mudah untuk mencapai tempat tujuan wisata baik skala internasional maupun akses dari satu destinasi ke destinasi lainnya.

Menurut Dann (1977) "these are factors that influence where tourists go travelling. pull factors are the attractiveness or "drawing power" of the destination as perceived by the traveler, and they are likely help traveler to make an actual destination choice ".

Tabel 2.3

Model pull factor dalam motivasi wisatawan

\begin{tabular}{|c|c|}
\hline $\begin{array}{c}\text { Knowledge dilihat dari } \\
\text { destinationatribute dan fasilitas }\end{array}$ & Aksesibilitas dan image pasar \\
\hline $\begin{array}{ll}\text { - } & \text { Iklim } \\
\text { - } & \text { Sejarah } \\
\text { - } & \text { Keindahan alam } \\
\text { - } & \text { Sinar Matahari } \\
\text { - } & \text { Event budaya } \\
\text { - } & \text { Rekreasi } \\
\text { - } & \text { Manfaat }\end{array}$ & $\begin{array}{l}\text { - Positif dan negatifnya suatu } \\
\text { destinasi dan atraksi wisata } \\
\text { - Kualitas dari servis yang diberikan } \\
\text { pada suatu destinasi dan atraksi } \\
\text { wisata. } \\
\text { - Kualitas dari fasilitas yang dimiliki } \\
\text { pada setiap destinasi dan atraksi } \\
\text { wisata. }\end{array}$ \\
\hline
\end{tabular}

(Sumber: Dann, 1977)

Wisatawan yang berdasarkan pada motovasi pull factor selalu didasari oleh persepsi wisatawan, ekspektasi wisatawan dan pengetahuan akan sebuah destinasi, atraksi wisata yang akan dikunjungi dan transportasi yang akan di gunakan dalam sebuah perjalanan wisata.

\subsection{Pola Pergerakan Wisatwan}

Dalam sebuah pola pergerakan selain dilihat dari faktor - faktor motivasi yang dapat mempengaruhi serta pengklasifikasian wisatawan terdapat juga beberapa kategori pola pergerakan wisatawan (tourist movement patterns).

Terdapat banyak penelitian sebelumnya yang berfokus mengkaji dan mempelajari bentuk - bentuk atau pola pergerakan wisatawan ini berdasarkan karakteristik ruang baik dalam tingkat atau cakupan yang lebih luas dimana pola tersebut terbentuk dari pergerakan wisatawan antar destinasi di wilayah atau daerah berbeda (inter-destination), ataupun dalam tingkat atau cakupan yang lebih sebih sempit, pergerakan tersebut terbentuk dari pergeraka antar atraksi wisata di sebuah destinasi (intra-destination).

Diantara penelitian tersebut yaitu Ming dan McHugh (1992) "Movement patterns of domestic tourist in Yellowstone National Park in the United States", Lue et al (1993) "Conceptualised five different patterns for pleasure, vacation trips at multidestination level: 'single destination', 'en-route', 'base camp', 'regional tour' and 


\section{National Conference of Creative Industry: Sustainable Tourism Industry for Economic Development \\ Universitas Bunda Mulia, Jakarta, 5-6 September 2018}

ISSN No:

'trip chaining' pattern", Oppermann (1995) yang menambahkan dua model pola pergerakan dari penelitian sebelumnya, berdasarkan survei wisatawan internasional di Malaysia yaitu 'open-jaw loop' dan 'multiple-destination area loop'. Flognfeldt (1999) yang mengidentifikasi empat tipe pola pergerakan di Norwegia yaitu: 'daytrip', resort-trip', 'based-holiday' dan 'round-trip'.

Dari penelitian - penelitian tersebut kemudian model atau kategori pola pergerakan wisatawan disempurnakan oleh penelitian Lau dan McKercher (2006) yang kemudian dikelompakkan dalam 6 kategori, yaitu yang tertera pada tabel 2.4.

Tabel 2.4

Pola Pergerakan Wisatawan

\begin{tabular}{|c|c|}
\hline Pola Pergerakan & Penjelasan \\
\hline Single Point & $\begin{array}{l}\text { Pergerakan yang menuju hanya satu } \\
\text { titik destinasi tanpa mengunjungi titik } \\
\text { destinasi lain dan kembali ke tempat } \\
\text { asal menggunakan rute yang sama }\end{array}$ \\
\hline Base Site & $\begin{array}{l}\text { Pola pergerakan yang menyerupai } \\
\text { sebaran sinar dengan satu titik pusat. } \\
\text { Wisatawan memulai perjalanan dari } \\
\text { tempat asal dan menuju tujuan utama } \\
\text { dan dilanjutkan melakukan kunjungan } \\
\text { ke tujuan sekunder dalam wilayah } \\
\text { tertentu }\end{array}$ \\
\hline $\begin{array}{l}\text { Stopover } \\
\text { Stopover }\end{array}$ & $\begin{array}{l}\text { Pergerakan yang menuju satu titik } \\
\text { destinasi utama dimana mengunjungi } \\
\text { titik destinasi lain (sekunder) dalam } \\
\text { proses pergerakannya }\end{array}$ \\
\hline $\begin{array}{l}\text { Chaining Loop } \\
\text { Chaining Loop }\end{array}$ & $\begin{array}{l}\text { Pergerakan dengan memutar seperti } \\
\text { cincin yang menghubungkan } 2 \text { titik atau } \\
\text { lebih titik dan tidak melakukan } \\
\text { pengulangan rute }\end{array}$ \\
\hline $\begin{array}{l}\text { Destination region loop } \\
\text { Destination region loop }\end{array}$ & $\begin{array}{l}\text { Perjalanan wisatawan yang dimulai } \\
\text { dengan rute mengelilingi destinasi } \\
\text { lainnya. Setelah menyelesaikan tur } \\
\text { secara berkeliling (pola lingkaran), } \\
\text { mereka kembali ke tempat asal melalui } \\
\text { rute yang paling singkat antara tujuan } \\
\text { utama dan tempat asal berangkat. Ini } \\
\text { merupakan kombinasi dari pola single }\end{array}$ \\
\hline
\end{tabular}


National Conference of Creative Industry: Sustainable Tourism Industry for Economic Development

Universitas Bunda Mulia, Jakarta, 5-6 September 2018

ISSN No:

\begin{tabular}{|l|l|}
\hline Complex neighbourhood & point dan chaining loop \\
\hline Complex neighbourhood & $\begin{array}{l}\text { Merupakan kombinasi dua atau lebih } \\
\text { pola - pola yang telah disebutkan diatas }\end{array}$ \\
\hline
\end{tabular}

Sumber : Lau \& McKercher, 2006

Adanya model pola pergerakan wisatawan ini akan memudahkan berkaitan dengan kegiatan perencanaan dan penyusunan pola perjalanan wisata yang ideal.

\section{METODE PENELITIAN}

Bab ini akan menjelaskan tentang jenis metodologi penelitian, objek penelitian, sampling, teknik pengumpulan data, fokus penelitian, dan analisa data.

\subsection{Jenis Metodologi Penelitian}

Metodologi penelitian yang digunakan dalam penelitian ini adalah metode penelitian deskriptif dengan pendekatan kualitatif,dimana penelitian ini bersifat interpretasi dari kondisi yang alamiah (natural setting) dan objek penelitian berkembang secara alamiah tanpa dimanipulasi oleh peneliti. Menurut Soegiyono (2011) "metode penelitian kualitatif bersifat holistik, dinamis, hasil konstruksi dan hasil dari pemahaman, dimana peneliti memiliki hubungan secara interaktif dengan sumber data agar diperoleh makna secara mendalam sehingga informasi yang didapat dapat di terapkan di tempat lain (transferability) yang memiliki kondisi yang sama".

Sedangkan menurut Creswell (2014):

"Qualitative research is an approach for exploring and understanding the meaning of individuals or groups ascribe to social or human problem. The prossess of research involves emerging questions and procedurs, data typicaly collected in the participans setting, data analysis inductively building from particulars to general themes, aansd the researcher making interpretation of the meaning of the data.

Maka pada penelitian ini peneliti harus mampu memahami interaksi sosial dengan cara ikut berperan serta menjadi salah satu staff di Sensa Hotel sebagai front office yang berinteraksi langsung dengan wisatwan Timur Tengah, wawancara secara mendalam pada interaksi sosial tersebut agar mampu melihat pola-pola hubungan yang jelas sehingga peneliti mampu menginterpretasikan makna dari data yang diperoleh. Sehingga peneliti mampu memberikan gambaran dengan cermat tentang 


\section{National Conference of Creative Industry: Sustainable Tourism Industry for Economic Development}

Universitas Bunda Mulia, Jakarta, 5-6 September 2018

ISSN No:

bagaimana profil wisatawan timur tengah dan bagaimana motivasi pola pergerakan wisatwaan Timur Tengah sehingga akan terbentuk pola perjalanan wisatawan Timur Tengah yang terpadu.

\subsection{Objek Penelitian}

Objek penelitian menurut Sugiyono (2004:13) Objek penelitian adalah sasaran ilmiah untuk mendapatkan data dengan tujuan dan kegunaan tertentu tentang sesuatu hal objektif, valid, dan reliable tentang suatu hal (variabel tertentu).

Sedangkan menurut Miles and huberman (dalam Creswell: 2014) sasaran ilmiah yang menjadi partisipan dalam penelitian yaitu ; settings (tempat dimana interaksi dalam situasi sosial sedang berlangsung), actors (pelaku atau orang - orang yang di teliti atau di wawancara), events( kejadian atau kegiatan yang akan diteliti dari partisipan) dan process (perkembanagan dari kondisi atau situasi kejadian di tempat penelitian ).

Bedasarkan pengertian diatas objek yang berkaitan dengan penelitian ini akanterfokus pada kondisi dayatarik wisata, fasilitas dan aksesibilitas dikota Bandung dengan melihat profil wisatawan Timur Tengah agar dapat membentuk pola perjalanan yang sesuai.

\subsection{Sampling}

Tujuan dari penelitian kualitatif adalah untuk memahami secara mendalam dan penilaian secara subjektif dari partisipan atau Informan. Dengan pengambilan sampel dan teknik pengambilan data secara cermat karena data akan diperoleh tidak berdasarkan banyaknya partisipan melainkan dilihat secara mendalam untuk menjawab pertanyaan penelitian.Teknik sampling yang digunakan oleh peneliti adalah purposive sampling dan accidental atau convenience sampling.

Purposive sampling merupakan teknik pengambilan sampel sumber data dengan beberapa pertimbangan, misalnya memilih partisipan yang dianggap bisa mewakili suatu kondisi yang diharapkan mampu memudahkan peneliti untuk menjelajahi objek atau situasi sosial yang diteliti secara mendalam. Sedangkan accidental atau convenience sampling adalah teknik penentuan sampel berdasarkan kebetulan, yaitu siapa saja yang secara kebetulan bertemu dengan peneliti dapat digunakan sebagai sampel (Sugiyono;2001). Begitu juga menurut Uma Sekaran (2003) "Convenience sampling refers to the collection of information from members of the population who are conveniently available to provide it".

Berdasarkan teori tersebut, pada penelitian ini yang mengkaji tentang pola perjalanan wisatawan Timur Tengah berdasarkan profil wisatawan dan motivasi pola pergerakan di Bandung. Maka peneliti memutuskan informan kunci yang di anggap paling sesuai dan tepat untuk mewakili suatu kondisi sosial yaitu wisatawan Timur Tengah yang memiliki lama tinggal 10 hari 9 malam. Lalu setelah itu peneliti memilih wisatawan Timur Tengah secara kebutulan atau acak yang dianggap dapat mengumpulkan data yang dipandang cocok sebagai sumber data.

\subsection{Teknik Pengumpulan Data}




\section{National Conference of Creative Industry: Sustainable Tourism Industry for Economic Development}

Universitas Bunda Mulia, Jakarta, 5-6 September 2018

ISSN No:

Teknik pengumpulan data merupakan suatu tahapan yang penting dalam sebuah penelitian dikarenakan proses pemilihan teknik pengumpulan data dapat mempengaruhi ke akuratan data yang akan di peroleh oleh peneliti.

Menurut Sugiyono (2013) Terdapat dua sumber dalam pengumpulan data yaitu sumber premier dan sumber sekunder.Sumber premier yaitu sumber data yang langsung memberikan data kepada peneliti, dan sumber sekunder yaitu sumber yang tidak langsung memberikan data kepada peneliti.

Sumber data primer yang didapatkan oleh peneliti dalam penelitian ini berasal dari Sensa Hotel dan hasil dari teknik pengumpulan data seperti; observasi, wawancara dan analisis dokumen. Sedangkan sumber data sekunder yang didapat berasal dari pra survei, data data pendukung dan internet.Adapun teknik - teknik pengumpulan data yang digunakan dalam penelitian ini yaitu:

a. Wawancara

Suatu wawancara akan terjadi jika adanya pertemuan dua orang yang saling bertukar informasi.Hancook (2009) mengemukakan beberapa jenis dari wawancara, yaitu wawancara terstruktur, wawancara semi struktur, dan wawancara tidak terstruktur. Wawancara terstruktur yaitu wawancara yang pertanyaan-pertanyaanya sudah di persiapkan, yang sudah mengetahui secara pasti informasi apa saja yang akan diperoleh. Sedangkan wawancara semi terstruktur yaitu wawancara yang lebih terbuka dan pelaksananya lebih bebas bila dibandingkan dengan wawancara terstruktur.

Wawancara semi stuktur menggunakan pertanyaan - pertanyaan yang lebih terbuka namun masih mengacu kepada topik penelitian, dimana partisipan atau informan diminta berpendapat, menuangkan gagasan-gagasan dan ide-ide yang didengarkan secara teliti dan seksama oleh pewawancara dengan mencatat apa yang dikemukakan informan.

Menurut Sugiyono (2013) "wawancara tidak terstruktur adalah wawancara yang bebas dimana peneliti tidak menggunakan pedoman wawancara yang telah tersusun secara sistematis dan lengkap untuk pengumpulan datanya.Pedoman wawancara yang digunakan hanya berupa garis besar pertanyaan".pada wawancara tidak terstruktur percakapan akan benar - benar terbuka dan mengalir namun akan mendalam tentang subjek yang akan diteliti.

Menurut Molleong (dalam Sugiyono 2013) menggolongkan enam jenis pertanyaan yang saling berkaitan yaitu:

1) Pertanyaan yang berkaitan dengan pengalaman

2) Pertanyaan yang berkaitan dengan pendapat

3) Pertanyaan yang berkaitan dengan perasaan

4) Pertanyaan tentang pengetahuan

5) Pertanyaan yang berkenaan dengan indera

6) Pertanyaan yang berkaitan dengan latar belakang atau demografi.

Alat yang akan digunakan oleh peneliti dalam wawancara yaitu ; Buku catatan (untuk mencatata semua percakapan yang disampaikan oleh 


\section{National Conference of Creative Industry: Sustainable Tourism Industry for Economic Development}

Universitas Bunda Mulia, Jakarta, 5-6 September 2018

ISSN No:

informan), Tape recorder (untuk merekam semua percakapan dengan informan), Camera.

Selain daripada itu, teknik wawancara yang akan digunakan oleh peneliti yaitu menggunakan teknik Collection of Narrative yaitu sebuah kisah yang diceritakan oleh dua atau lebih informan yang memberikan sebuah data untuk peneliti.

Menurut Hancook (2009) "The "narrative interview" begins with a "generative narrative question" which invites the interviewee to relate his/her account of his/her life history or a part of it ". darinarative interview peneliti akan mengenal informan secara personal dan mendalam dengan mendengarkan secara seksama tanpa mencela sampai informan selesai bercerita, setelah selesai peneliti dibolehkan untuk menggali lebih dalam dengan sebuah pertanyaan yang terkait.

b. Observasi

Tidak semua pengumpulan data dalan metode kualitatif memerlukan interaksi langsung dengan informan, observasi merupakan tenik yang dapat digunakan untuk memvalidasi dan memverifikasi karena peneliti akan mengamati apa yang dilakukan oleh informan sehingga peneliti mendapatkan informasi yang sesuai ketika bertatap muka atau wawancara.

Peneliti yang merupakan salah satu staff hotel yang memiliki akses kemudahan untuk berinteraksi langsung dengan wisatwan Timur Tengah sehingga peneliti melakukan observasi dengan mengamati pola pergerakan wisatawan Timur Tengah selama melakukan perjalanan wisata di Bandung.

Sehingga peneliti dapat menentukan informan yang akan di teliiti dan juga mendapatkan informasi secara mendalamam untuk kepentingan penelitian.

Menurut Sugiyono (2013) Teknik observasi digolongkan menjadi tiga bagian yaitu: Observasi partisipatif (peneliti terlibat langsung dengan kegiatan sehari-hari informan), Observasi terus terang atau tersamar (Informan mengetahui bahwa peneliti akan melakukan penelitian tetapi dalam suatu waktu peneliti juga tidak terus terang atau tersamarkan guna untuk mendapatkan data yang masih dirahasiakan), dan Observasi tak berstruktur.(peneliti tidak mempersiapkan secara terstrukturatau sistematis tentang apa yang akan di observasi).

c. Analisa dokumen

Analisa dokumen merupakan teknik pengumpulan data pelengkap dari teknik observasi dan wawancara.Menurut Sugiyono (2013) "Dokumen meripakan catatan peristiwa yang sudah berlalu, yang bisa berbentuk tulisan, gambar, atau karya karya monumental dari seseorang".

Dokumen yang telah diperoleh kemudian dianalisis, dibandingkan dan dipadukan (sintesis) membentuk suatu kajian yang sistematis, padu dan utuh.Dokumen sebagai sumber data banyak dimanfaatkan para peneliti terutama untuk menguji, menafsirkan dan bahkan untuk meramalkan. Maka daripada itu peneliti akan menggunakan studi dokumentasi untuk 


\section{National Conference of Creative Industry: Sustainable Tourism Industry for Economic Development}

Universitas Bunda Mulia, Jakarta, 5-6 September 2018

ISSN No:

mengumpulkan data-data sekunder yang terdapat di Sensa Hotel Bandung berupa data-data tentang penyediaan transportasi untuk wisata, brosur dan data pengunjung serta data lain yang diperlukan untuk mendukung kelengkapan data dalam penelitian ini.

Dokumen yang digunakan peneliti dalam penelitian ini berupa foto, gambar serta data - data mengenai wisatwan Timur Tengah yang di dapat dari Sensa Hotel.

\subsection{Analisa data}

Analisa data merupakan hal yang penting guna mendapatkan hasil data yang akurat.Menurut Miles dan Huberman (1994) dalam analisis data kualitatif terdiri dari tiga prosedur, yaitu:Data reduction, Data Display, and Conclusion drawingatau verification.

a. Data reduction(reduksi data) pada tahap ini akan adanya pengurangan informasi yang tidak relevan, coding atu menulis ringkasan dari transkip wawancara, catatan catatan dilapangan, pengamatan dan studi dokumentasi. Reduksi data yang melalui proses coding, akan terdapat beberapa data yang tidak relevan namun dapat dibuka atau open coding, axial atau selektif dan kemudian kode tersebut dapat ditampilkan atau gambarkan dalam bentuk kesimpulan.

b. Data Display (penyajian data) untuk menarik kesimpulan dari sebuah data perlu adanya klasifikasi data, kategorisasi data dan menyatukan beberapa data yang memiliki kesamaan.Menurut Miles dan Huberman data yang baik yaitu dalam bentuk tabel, grafik, jaringan atau grafik lain yang juga penting.

c. Conclusion drawingatau verification (penarikan kesimpulan dan verifikasi) pengembanagan kesimpulan tentang analisa data yang sudah akurat, yang kemudian diverifikasi yang keabsahannya sudah teruji melalui referensi untuk menjawab permasalahan yang muncul dalam penelitian.

Selain dari beberapa hal tersebut, untuk mengurangi kesalah pahaman atau misconception dalam analisa data, peneliti menambahkan data analisis menggunakan triagulation atau triangulasi data guna mengecek ke abshan sebuah data. Menurut Denzin (dalam Moloeng,2004) metode triangulasi di bedakan menjadi empat macam yaitu ; dengan memanfaatkan penggunaan sumber, metode, penyidik dan teori. Pada penelian ini peneliti hanya menggunakan teknik pemeriksaan dengan memanfaatkan sumber.

\section{HASIL PENELITIAN DAN PEMBAHASAN}

Bab ini membahas tentang hasil penelitian dan pembahasan tentang pola perjalanan wisatawan dilihat dari daya tarik wisatawa, fasilitas dan aksesibilitas berdasarkan profil wisatawan dan motivasi pola pergerakan. Hasil penelitian ini di dapat oleh peneliti dengan menggunakan metode wawancara pada tamu Timur Tengah yang menginap di salah satu hotel bintang 4 di Bandung, pada bulan Desember 2016 sampai dengan January 2017. 


\section{National Conference of Creative Industry: \\ Sustainable Tourism Industry for Economic Development \\ Universitas Bunda Mulia, Jakarta, 5-6 September 2018}

\subsection{Data Penelitian dan pembahasan pada aspek pola perjalanan}

ISSN No:

Pola perjalanan wisatawan pada penelitian ini terbentuk berdasarkan daya tarik wisata serta aksesibilitas dan fasilitas.Daftar daya tarik wisata, aksesibilitas dan fasilitas ini telah disesuaikan dengan minat wisatawan Timur Tengah.

\subsubsection{Data Penelitian Daya Tarik Wisata}

Tabel dibawah ini menjelaskan tentang tentang pola perjalanan wisatawan Timur Tengah berdasarkan daya tarik wisatadi Bandung yang dikategorikan kedalam daya tarik wisata alam, daya tarik wisata buatan dan daya tarik wisata budaya 
National Conference of Creative Industry:

Sustainable Tourism Industry for Economic Development

Universitas Bunda Mulia, Jakarta, 5-6 September 2018

Tabel 4.1

Data Penelitian Daya Tarik Wisata

Pengumpulan data penelitian tentang daya tarik wisata ini dilakukan melalui wawancara dengan 3 informan dalam waktu yang berbeda, pada periode Desember 2016 sampai dengan Januari 2017.

\begin{tabular}{|c|c|c|c|c|c|}
\hline $\begin{array}{c}\text { Fokus } \\
\text { Penelitian }\end{array}$ & \multicolumn{2}{|c|}{ Sub Fokus Penelitian } & Informan 1 & Informan 2 & Informan 3 \\
\hline 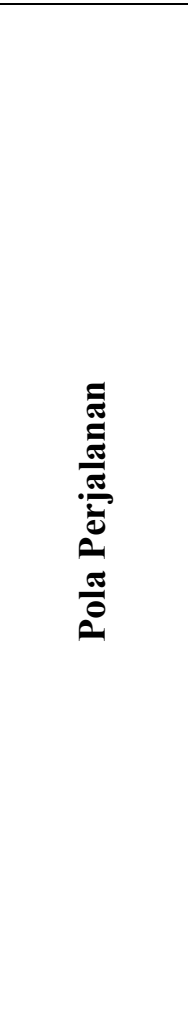 & $\begin{array}{c}\text { Daya Tarik } \\
\text { Wisata }\end{array}$ & $\begin{array}{c}\text { Daya } \\
\text { Tarik } \\
\text { Wisata } \\
\text { Alam }\end{array}$ & $\begin{array}{l}\text { Informan memiliki lama tinggal } \\
\text { atau length of stay } 4 \text { hari } 3 \text { malam, } \\
\text { sehingga informan memiliki } \\
\text { waktu yang cukup untuk } \\
\text { mengeksplore daya tarik wisata di } \\
\text { Bandung.Informan tertarik pada } \\
\text { daya tarik wisata Alam, dimana } \\
\text { mereka dapat menikmati udara } \\
\text { yang sejuk, aktiftas fisik seperti } \\
\text { wisata air terjun, pemandian air } \\
\text { panas dan shopping. } \\
\text { Perjalanan menjelajahi Bandung } \\
\text { di bagi sesuai dengan wilayahnya, } \\
\text { untuk hari pertama informan akan } \\
\text { melakukan perjalanan untuk } \\
\text { menjelajahi lembang dang } \\
\text { sekitarnya, kemudian dihari } \\
\text { beirkutnya kawah putih dan } \\
\text { beberapa atraksi wisata sekitar } \\
\text { lalu untuk hari terakhir informan } \\
\text { akan menghabiskan waktu untuk }\end{array}$ & $\begin{array}{l}\text { Informan memiliki lama tinggal } \\
10 \text { Hari } 9 \text { Malam, aktifitas yang } \\
\text { lakukan yaitu explore daya tarik } \\
\text { wisata alam dan buatan, seperti } \\
\text { tangkuban perahu, hot spring } \\
\text { water, sightseeing kebun teh.area } \\
\text { area yang memiliki cuaca sejuk, } \\
\text { bisa membuat relax dan shopping. } \\
\text { informan tidak tertarik untuk } \\
\text { melakukan aktivitas tracking di } \\
\text { hutan atau gua, dan Musium. }\end{array}$ & $\begin{array}{l}\text { Informan hanya memiliki lama } \\
\text { tinggal } 5 \text { Hari } 4 \text { malam, informan } \\
\text { mengatakan bahwa banyak nya } \\
\text { daya tarik wisata yang bagus di } \\
\text { bandung namun beberapa tourist } \\
\text { belum mengetahuinnya } \\
\text { dikarenakan kurang nya informasi } \\
\text { yang diberikan, seharusnya } \\
\text { Bandung memiliki booklet atau } \\
\text { Peta yang di distribusikan kepada } \\
\text { hotel - hotel atau ketika } \\
\text { sesampainya di bandara adanya } \\
\text { touris information yang } \\
\text { menjelaskan semuanya sehingga } \\
\text { dapat memudahkan para } \\
\text { wisatawan. untuk daya tarik } \\
\text { wisata yang di pilih hanya daya } \\
\text { tarik wisata alam seperti } \\
\text { tangkuban perahu, Cimahi } \\
\text { Waterfall. a }\end{array}$ \\
\hline
\end{tabular}


National Conference of Creative Industry:

Sustainable Tourism Industry for Economic Development

Universitas Bunda Mulia, Jakarta, 5-6 September 2018

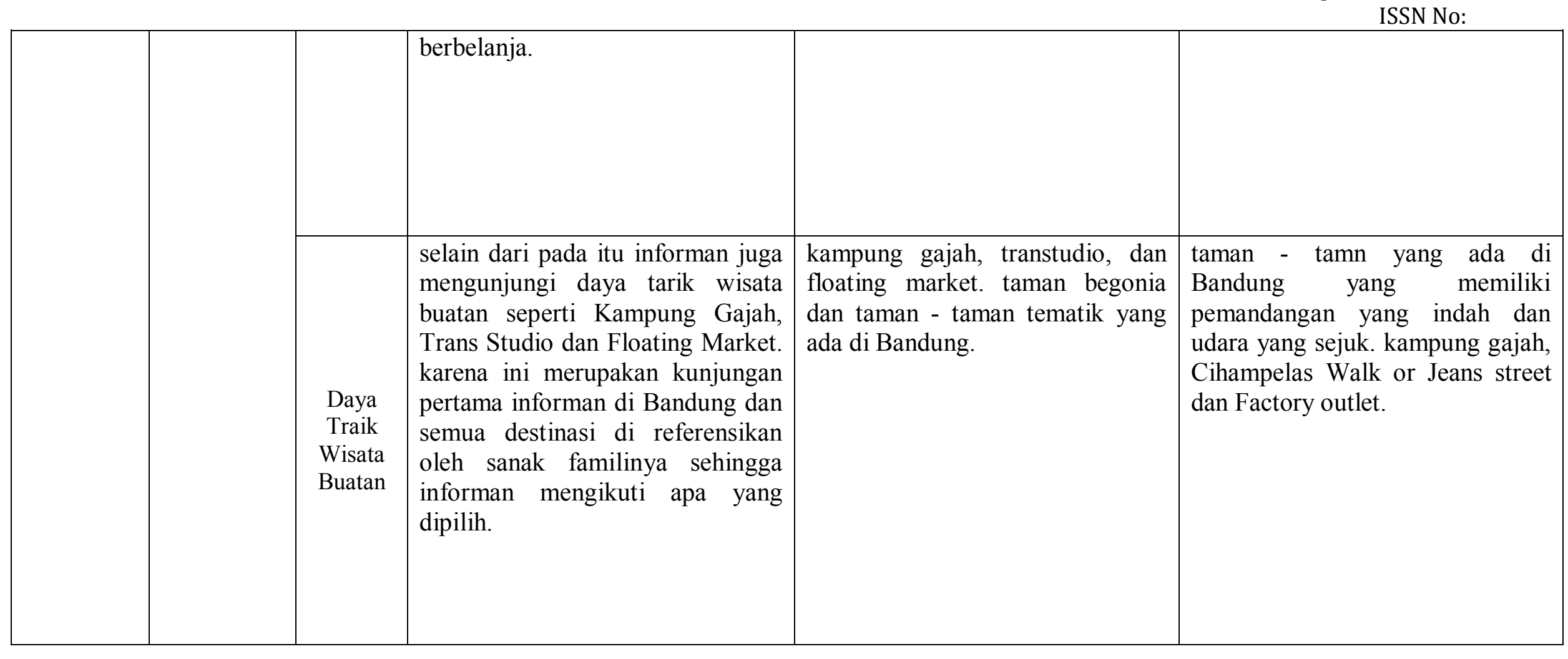


National Conference of Creative Industry:

Sustainable Tourism Industry for Economic Development

Universitas Bunda Mulia, Jakarta, 5-6 September 2018

ISSN No:

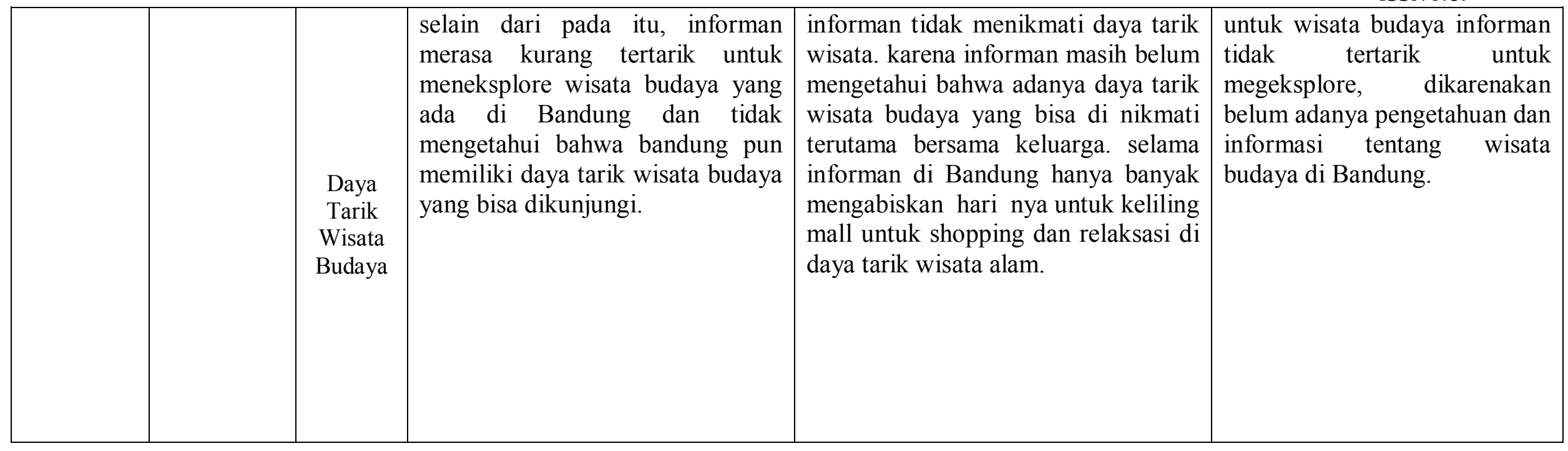




\section{National Conference of Creative Industry: Sustainable Tourism Industry for Economic Development}

Universitas Bunda Mulia, Jakarta, 5-6 September 2018

ISSN No:

Pada tabel 4.1 ini menyatakan bahwa Ketiga informan memiliki pendapat yang sama, yakni Bandung memiliki daya tarik wisata yang bagus dan sangat menarik untuk di explore, ketika informan memiliki lama tinggal yang lebih dari 2 hari 1 malam, dimana informan 1 memiliki lama tinggal 4 hari 3 malam. Informan 2 memiliki lama tinggal 10 Hari 9 malam dan informan 3 memiliki lama tinggal 5 hari 4 malam. Dimana ini merupakan waktu yang cukup untuk mengkesplore Bandung. Namun ketiga informan memiliki kategori daya tarik wisata yang sama yaitu lebih memilih untuk mengunjungi daya tarik wisata alam dan daya tarik wisata buatan. Daya tarik wisata alam yang diminati oleh ketiga informan seperti: Pemandian air panas sariater, air terjun curug cimahi, kebun teh, dan kebun strawberry. Wisata alam selalu menjadi daya tarik unggulan untuk wisatawan Saudi Arabia dikarenakan Bandung memiliki hamparan alam yang cantik, indah, ditambah lagi bandung memiliki suhu cuaca yang sejuk sehingga membuat wisatawan Timur Tengah merasa nyaman untuk menikmati keindahan alam yang ada. Selain itu jika dilihat pada tabel 4.1 kategori utama lainnya yaitu daya tarik wisata buatan, seperti: Trans studio, kampung gajah, floating market dan taman - taman yang ada di Bandung.

Daya tarik wisata buatan menjadi alternatif pilihan daya tarik wisata yang dikunjungi karena wisatawan Timur Tengah yang berkunjung ke Bandung tidak seorang diri, selalu ber group atau melakukan perjalananya bersama sanak famili minimal 2 sampai 15 Orang.

Daya tarik wisata budaya tidak diminati oleh ketiga informan. Hal ini dapat terlihat dalam data di tabel 4.1. jika informan satu tidak mengunjungi daya tarik wisata yang ada di Bandung dikarenakan itinerary yang dimiliki merupakan saran dari sanak familynya yang sudah pernah berkunjung terlebih dahulu ke Bandung, dan sanak famili-nya tidak memasukkan list untuk mengunjungi daya tarik wisata budaya yang ada di Bandung. Untuk informan ke dua, walau lama huniannya 10 hari di Bandung, tidak menyisakan satu hari pun untuk mengeksplore wisata budaya yang ada di Bandung, dikarenakan kurangnya informasi mengenai daya tarik wisata budaya tersebut dan tidak adanya promosi yang dapat meyakinkan informan bahwa daya tarik wisata budaya di Bandung sangat menarik untuk di kunjugi. Informan ketiga memang tidak berminat untuk mengunjungi daya tarik wisata budaya dan informan pun kurang mengetahui dan tidak mencari informasi tentang adanya wisata budaya di Bandung, sehingga destinasi yang di kunjunginya merupakan destinasi yang sudah pernah dikunjungi sebelum kedatangannya di periode ini.

\subsubsection{Pembahasan Analisis Daya Tarik Wisata}

Menurut pendapat dari ketiga informan,daya tarik wisata utama yang menjadi pilihan oleh wisatawan Timur Tengah yaitu daya tarik wisata alam seperti : Gunung Berapi Tangkuban Perahu, Kawah Dolmas, Curug Pelangi, Tebing Keraton, Kawah Putih,Situ Patengan dan daya tarik wisata buatan seperti ; Kampung Gajah, Sari Ater Hot Spring Resort, Floating Market, Kebun Strawberry Lembang, Trans Studio Bandung.

Selain memiliki keindahan alam dengan iklim cuaca yang sejuk juga banyaknya daya tarik wisata buatan yang banyak di nikmati oleh wisatawan yang berkeluarga, 


\section{National Conference of Creative Industry: Sustainable Tourism Industry for Economic Development}

Universitas Bunda Mulia, Jakarta, 5-6 September 2018

ISSN No:

Sehingga di mata wisatawan Timur Tengah, Bandung merupakan destinasi wisata yang ramah untuk keluarga. Selain daripada itu, yang menjadi faktor pendukung bahwa bandung merupakan destinasi yang dikunjungi oleh wisatawan Timur Tengah yang berkeluarga adalah dengan banyak nya shopping center dan factory outlet.

Pusat perbelanjaan dan factory outlet merupakan salah satu destinasi yang utama yang di kunjungi oleh wisatawan timjr tengah yang berkunjung dengan keluarga. Selain memiliki kualitas barang yang baik, jenis barangnya pun sangat beragam.berikut beberapa mall dan factory outlet yang banyak di minati oleh wisatawan Timur Tengah ; Jeans Street Cihampelas, Heritage Factory Outlet, Rumah Mode dan Paris Van Java Mall.

Jika dilihat dari data tersebut, bahwasanya wisatawan Timur Tengah masih tergolong kepada wisatawan yang bersifat recretional. Karena wisatawan Timur Tengah yang berkunjung ke Bandung tidak memiliki minat untuk mengeksplorasi daya tarik wisata budaya. Sedangkan menurut Spillane (2003), produk pariwisata budaya memiliki segmen pasar khusus yaitu para "knowledge workers". Knowledge worker pada istilah kepariwisataan disebut juga sebagai "Mature Tourism", dimana wisatawan yang melakukan suatu perjalanan cenderung termotivasi untuk mencari pengalaman dengan terlibat langsung dengan aktivitas aktivitas masyarakat setempat, mempelajari searah dan budaya yang ada di suatu daerah yang dikunjunginya.

\subsubsection{Data Penelitian Aksesibilitas \& Fasilitas}

Tabel dibawah ini menjelaskan tentang tentang pola perjalanan wisatawan Timur Tengah berdasarkan aksesibilitas dan fasilitasdi Bandung yang dibagi menjadi 2 kategori yaitu kategori infrastruktur dan kategori superstruktur. 
National Conference of Creative Industry:

Sustainable Tourism Industry for Economic Development

Universitas Bunda Mulia, Jakarta, 5-6 September 2018

Tabel 4.2

ISSN No:

Fasilitas dan Aksesibilitas

Pengumpulan data penelitian tentang fasilitas dan aksesibilitas ini dilakukan melalui wawancara dengan 3 informan dalam waktu yang berbeda, pada periode Desember 2016 sampai dengan Januari 2017.

\begin{tabular}{|c|c|c|c|c|c|}
\hline $\begin{array}{c}\text { Fokus } \\
\text { Penelitian }\end{array}$ & & $\begin{array}{l}\text { Fokus } \\
\text { pelitian }\end{array}$ & Informan 1 & Informan 2 & Informan 3 \\
\hline \multirow[t]{2}{*}{ 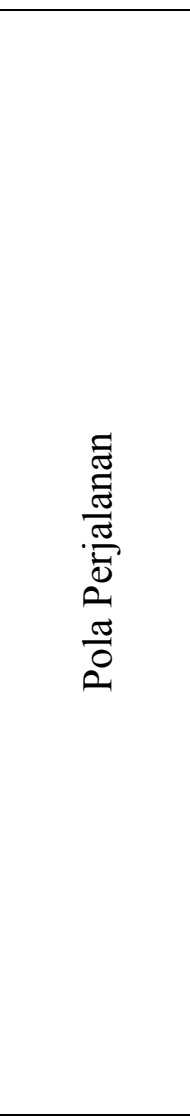 } & \multirow[t]{2}{*}{ 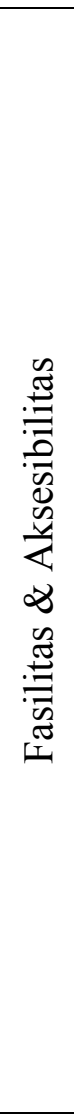 } & $\begin{array}{c}\text { Infrastruktu } \\
\mathrm{r}\end{array}$ & $\begin{array}{l}\text { Informan menggunakan pesawat } \\
\text { langsung dari Saudi Arabia } \\
\text { menuju Jakarta, transit menginap } \\
1 \text { hari dijakarta kemudian } \\
\text { menggunakan mobil rental } \\
\text { menuju puncak dan kemudian } \\
\text { Bandung. } \\
\text { mengeluhkan Jalan menuju daya } \\
\text { tarik wisata yang satu dengan } \\
\text { daya taraik wisata lainnya sangat } \\
\text { macet terutama di hari weekend. } \\
\text { Namun di sepanjang jalanmenuju } \\
\text { objek wisata terdapat banyak } \\
\text { masjid dan toilet. }\end{array}$ & $\begin{array}{l}\text { Informan menggunakan pesawat } \\
\text { langsung dari Saudi Arabia menuju } \\
\text { Jakarta, transit menginap } 2 \text { hari di } \\
\text { Jakarta kemudian menggunakan } \\
\text { mobil rental menuju Bandung. } \\
\text { kemacetan merupakan suatu } \\
\text { kendala yang dikeluhkan oleh } \\
\text { informan mengenai infrastruktur di } \\
\text { Bandung, namun informan sangat } \\
\text { memahami tentang kondisi } \\
\text { tersebut,sehingga informan } \\
\text { memilihakomodasi yang memiliki } \\
\text { akses dekat dengan shopping center } \\
\text { atau mall. }\end{array}$ & $\begin{array}{l}\text { Informan menggunakan pesawat } \\
\text { langsung dari Saudi Arabia } \\
\text { menuju Jakarta, transit menginap } \\
2 \text { hari di Jakarta kemudian } \\
\text { menggunakan mobil rental } \\
\text { menuju Bandung. Kemacetan juga } \\
\text { menjadi masalah bagi informan } \\
\text { namun informan cukup mengerti } \\
\text { dengan situasi jalan yang ada di } \\
\text { Bandung, informan menyiasatinya } \\
\text { dengan memilih akomodasi yang } \\
\text { memiliki akses yang mudah } \\
\text { ditengah keramaian dan diutaman } \\
\text { yang berada dekat dengan } \\
\text { perbelanjaan. }\end{array}$ \\
\hline & & $\begin{array}{c}\text { Superstrukt } \\
\text { ur }\end{array}$ & $\begin{array}{l}\text { Kategori superstruktur seperti } \\
\text { Akomodasi yang dipakai adalah } \\
\text { Hotel bintang 4, karena } \\
\text { rekomendasi dari sanak family } \\
\text { bahwasanya hotel tersebut } \\
\text { memiliki fasilitas yang dekat } \\
\text { dengan mall dan kemudahan }\end{array}$ & $\begin{array}{l}\text { Untuk akomodasi yang dipilih yaitu } \\
\text { bintang } 4 \text { ke atas pilihan utamanya } \\
\text { yaitu Sensa Hotel, karena memiliki } \\
\text { excelent service dari setiap staff } \\
\text { nya, ramah, friendly, danhelpful. } \\
\text { Selain dari pada itu Sensa Hotel } \\
\text { pun memiliki lokasi yang sangat }\end{array}$ & $\begin{array}{l}\text { Jenis Akomodasi yang dipilih } \\
\text { merupakan akomodasi yang } \\
\text { memiliki lokasi yang bagus, dekat } \\
\text { dengan mall dan memiliki service } \\
\text { oriented. untuk pemesanan } \\
\text { akomodasi selalu dilakukan } \\
\text { melalui online namun selalu }\end{array}$ \\
\hline
\end{tabular}


National Conference of Creative Industry:

Sustainable Tourism Industry for Economic Development

Universitas Bunda Mulia, Jakarta, 5-6 September 2018

ISSN No:

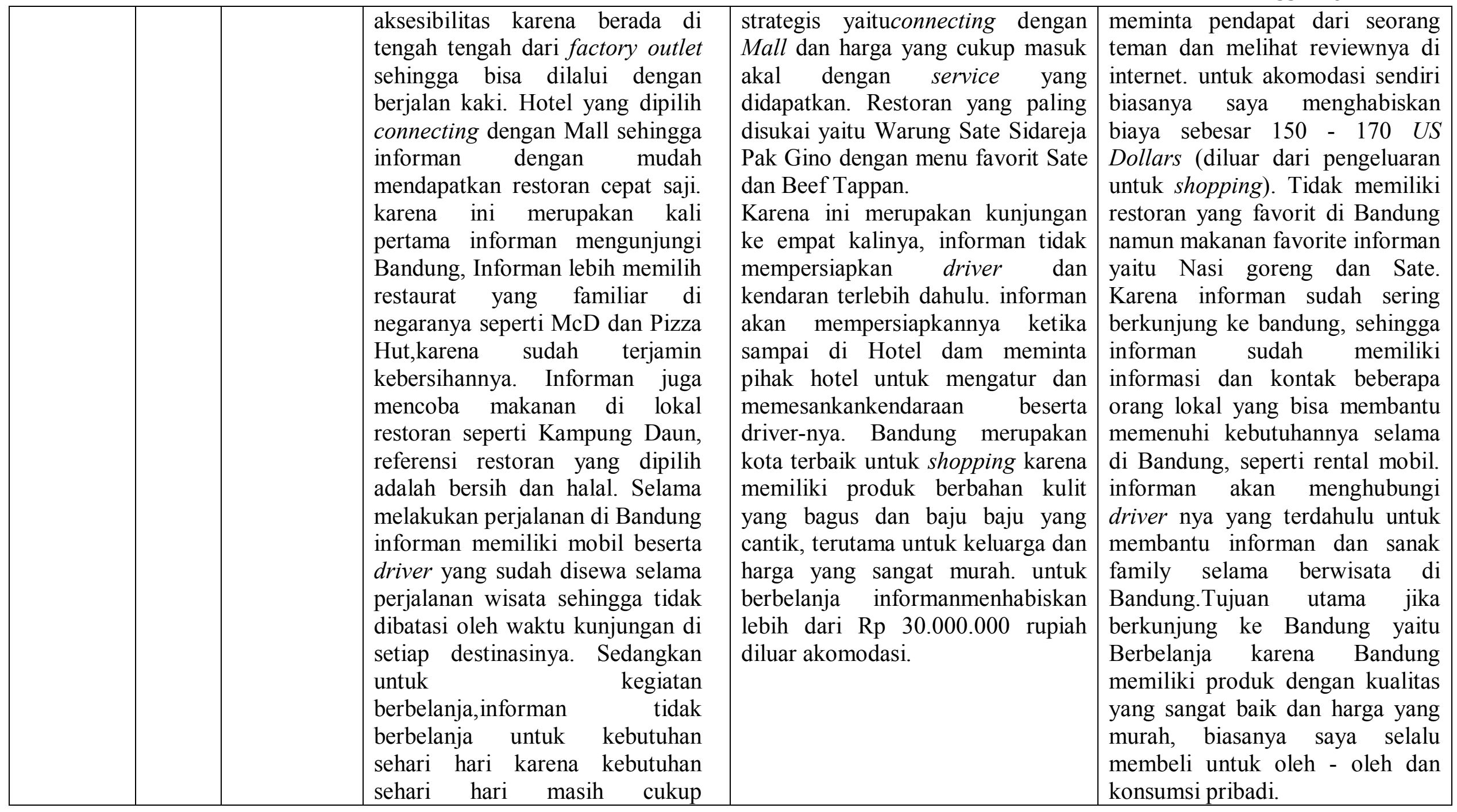


National Conference of Creative Industry:

Sustainable Tourism Industry for Economic Development

Universitas Bunda Mulia, Jakarta, 5-6 September 2018

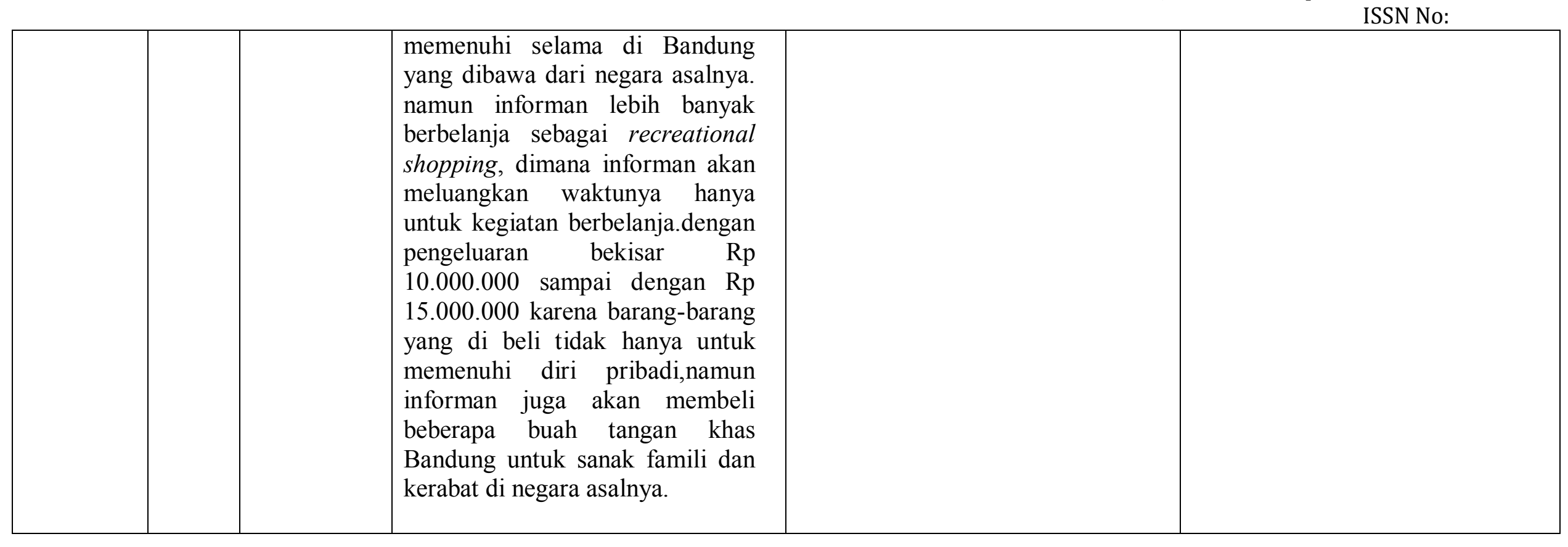




\section{National Conference of Creative Industry: Sustainable Tourism Industry for Economic Development}

Universitas Bunda Mulia, Jakarta, 5-6 September 2018

ISSN No:

Pada tabel 4.2 tentang fasilitas dan aksesibilitas menyatakan bahwa Ketiga informan menggunakan pesawat yang tidak lansung dari saudi arabia menuju Bandung, semua menggunakan pesawat dari saudi arabia sampai di Jakarta dan kemudian menginap untuk beberapa hari di Jakarta. Untuk informan satu menginap di Jakarta hanya 1 malam, kemudian menuju puncak dan menginap selama 4 hari kemudian ke Bandung.

Adanya kemudahan perjalan yang di tempuh dari Jakarta sebagai kota transit menuju destinasi destinasi wisata yang dituju baik ke Puncak maupun ke Bandung, begitu pun sebaliknya sebagai kota terakhir yang dikunjungi sebelum bertolak ke negaranya masing - masing,dengan kemudahan fasilitas jalan tersebut membuat wisatawan Timur Tengah nyaman untuk menjalajahi jawabarat dan Bandung khususnya.

Namun kemacetan jalan di destinasi yang di tuju seperti Bandung merupakan suatu kendala yang dikeluhkan oleh ketiga informan, sehingga dalam satu hari hanya dapat mengunjungi maksimal 3 daya tarik wisata, bahka jika weekend hanya dapat mengunjungi 1 daya tarik wisata.maka dari itu ketiga informan menyiasatinya dengan memilih akomodasi atau hotel yang memiliki kemudahan akses, berada di tengah tengah pusat keramaian dan berdekatan dengan pusat perbelanjaan.

Selain beberapa kriteria diatas, kriteria akomodasi lainnya yang di pilih oleh ke tiga informan yaitu hotel atau akomodasi berbintang 4. Informan 1 memilih hotel tersebut karena itu merupakan rekomendasi dari sanak famili yang menginap di hotel tersebut ketika berkunjung ke Bandung, hotel tersebut berada di tengah - tengah factory outlet, memiliki connecting dengan mall, aksesibilitas yang mudah sehingga informan dapat memenuhi segala kebutuhannya seperti mendapatkan restoran dengan mudah. Karena ini merupakan kunjungannya pertama kali ke Bandung, restoran yang di pilih lebih kepada restoran yang familiar atau menu yang mereka kenal, contohnya seperti restoran cepat saji Pizza Hut dan Mcd. Informan juga mencoba makanan di restoran lokal seperti kampung daun, restoran yang dipilih harus lah yang bersih dan halal.

Berbeda dengan informan 1, informan 2 dan informan 3 selalu memilih hotel yang sama selama kunjungan di Bandung, mereka memilih hotel tersebut karena keramahannya, service oriented, staffnya yang sigap untuk membantu, serta lokasi yang dangat strategis dan connecting dengan mall. menurut Informan 2 hotel tersebut memiliki harga yang terjangkau untuk hotel berbintang 4 dengan memiliki fasilitas dan aksesibilitas yang baik untuk informan 3 untuk biaya akomodasi saja biasanya menghabiskan biaya sekitar 150 - 170 US Dollars. Para informan melakukan pembookingan hotel melalui Online Travel Agent yang mereka lakukan sebelum keberagkatanya ke Indonesia, biasanya mereka memesan satu bulan sebelumnya.

Selain itu, untuk menu makanan dan restauran yang ada di Bandung, informan 2 dan 3 sudah mempunyai menu favorit dan restoran yang harus dikunjungi ketika di Bandung. Untuk informan 2 restoran yang wajib di kunjungi ketika ada di Bandung yaitu Warung Sate Sidareja Pak Gino dengan favorite menunya yaitu Sate dan Beef Tappan. Sedangkan untuk informan 3tidak memiliki restoran lokal yang dijadikan 


\section{National Conference of Creative Industry: Sustainable Tourism Industry for Economic Development}

Universitas Bunda Mulia, Jakarta, 5-6 September 2018

ISSN No:

favorite, bisa lokal restoran apa saja yang ada di Bandung yang penting bersih dan menyediakan menu Sate dan Nasi Goreng.

Kegiatan lainnya selain mengeksplore keindahan alam yang ada di Bandung yang telah dilakukan dari ketiga informan selama di Bandung yaitu berbelanja. Jika Informan 1 meluangkan satu hari terakhir untuk berbelanja, informan 2 dan informan 3 tidak memiliki batasan waktu untuk berbelanja karena mereka tidak mempunyai planning yang pasti selama di Bandung. Pengeluaran informan 1 untuk berbelanja baik untuk diri sendiri maupun untuk oleh - oleh yang akan dibawa pulang untuk sanak family beserta rekan - rekan di negara asalnya sebesar Rp 10.000.000 sampai dengan Rp 15.000.000. berbeda dengan informan 2 dan informan 3 yang sudah memili Image bahwa Bandung merupakan kota terbaik untuk shopping karena memiliki kualitas produk yang sangat baik dengan harga yang sangat murah. Untuk berbelanja informan 2 menghabiskan dana sebesar Rp 15.000.000 sampai dengan Rp 30.000.000 rupiah di luar akomodasidan barang yang harus di beli yaitu barang barang yang berbahan kulit. Untuk informan 3 dana yang di habiskan untuk berbelanja sebesar Rp 15.000.000 sampai dengan Rp 30.000.000 Rupiah.

Untuk aksesbilitas selama di Bandung, informan 1 menggunakan penyewaan mobil beserta driver yang mengerti bahasa arab untuk menemaninya selama perjalanan wisatanya di Bandung. Penyewaan mobil dan driver dilakukan sebelum kedatangannya di Indonesia dan ini merupakan penyewaan mobil dan driver yang melayani sanak familynya yang pernah berkunjung sebelumnya. Informan 2 dan 3 bermalam di jakarta selama 2 hari lalu menuju Bandung. Informan 2 hanya menyewa mobil untuk drop di Hotel Bandung saja, karena di Bandung informan akan sewa mobil beserta driver yang berbeda, begitupun di hari berikutnya, selesai kunjungannya di Bandung informan 2 akan menuju puncak dan penyewaan mobilnya hanya drop sampai puncak dan kemudian informan akan menggunaan penyewaan mobil beserta driver yang ada di puncak selama informan menginap di Puncak dan sampai hari akhirnya di Jakarta. Karena ini merupakan kunjungannya yang ke empat di Bandung, informan 3 sudah memiliki beberapa nomor kontak orang lokal yang bisa membantu memenuhi kebutuhannya selama di Bandung termasuk kebutuhan akan kendaraan dan driver.

\subsubsection{Pembahasan Analisis Aksesibilitas \& Fasilitas}

Wisatawan Timur Tengah yang datang ke Indonesia, khususnya mereka yang mengunjungi Kota Bandung tergolong mapan dengan tingkat ekonomi dan penghasilan yang cukup tinggi.Hal tersebut berpengaruh terhadap pemilihan Akomodasi.Akomodasi atau hotel yang menjadi pilihan wisatawan Timur Tengah adalah Hotel berbintang 4 yang memiliki kualitas fasilitas yang baik dan dalam hal pelayanan dapat memberikan personal touching (hubungan dengan internal motivation) kepada tamunya.

Lokasi hotel itu sendiri juga sangat mempengarui minat wisatawan Timur Tengah, wisatawan Timur Tengah memilih lokasi yang berada di daerah sekitar pusat kota dan berdekatan dengan berbagai fasilitas yang dapat memenuhi kebutuhan mereka. 


\section{National Conference of Creative Industry: Sustainable Tourism Industry for Economic Development}

Universitas Bunda Mulia, Jakarta, 5-6 September 2018

ISSN No:

Untuk memenuhi kebutuhan dasarnya (makan dan minum), Wisatawan Timur Tengah memiliki kelonggaran dalam pilihannya. pilihan restoran untuk wisatawan Timur Tengah sesuai dengan karakteristik dan motivasi mereka. Pilihan pertama adalah Restoran atau tempat makan yang menyediakan berbagai makanan khas dari daerah Timur Tengah. Pilihan ini biasanya datang dari wisatawan yang baru pertama kali datang ke Bandung. Pilihan Kedua adalah Restoran atau tempat makan yang yang menyediakan berbagai varian makanan berbahan dasar daging. Tentunya didukung dengan atmosfer yang nyaman.

Selama berada di Bandung, wisatawan Timur Tengah menggunakan private car yang dibawa oleh tour guide mereka, baik ketika bepergian ke suatu destinasi atau objek daya tarik wisata sesuai dengan harga yang telah disepakati sebelumnya.

Menurut Yoeti (1997) Bahwa aksesibilitas adalah kemudahan dalam mencapai daerah tujuan wisata baik secara jarak geografis atau kecepatan teknis, serta tersediannya sarana transportasi ketempat tujuan. Kemudahan aksesibilitas yang ada di Bandung yang menjadi alasan ketiga informan untuk menghabiskan lama tinggal untuk mengeksplor Bandung.

Selain di tunjang dengan daya tarik wisata dan aksesibilitas yang memudahkan wisatawan Timur Tengah, fasilitas berbelanja juga menjadi suatu hal yang penting, karena wisatawan Timur Tengah akan banyak meluangkan waktu nya untuk berbelanja. Wisatawan Timur Tengah melakukan aktifitas berbelanja sebagai suatu recreational shopping.

Dimana menurut Timothy (1993) recreational shopper dimana wisatawan yang melakukan aktivitas berbelanjan dengan lebih spontan, menghabiskan waktu luangnya untuk berbelanja dan akan melakukan berbelanja setelah melakukan pembelian.

\subsection{Hasil Analisis dan Pembahasan Pada Aspek Profil Wisatawan}

Dalam pembentukan pola perjalanan perlu adanya profil wisatawan sebagai gambaran umum tentang karakteristik wisatawan yang dilihat dari faktor sosiodemografi, psikografi, dan tipe wisatawan.

\subsubsection{Data Penelitian Aspek Sosiodemografi}

Tingkat dan pola perjalanan wisata dapat dipengaruhi oleh karakteristik sosial dan demografi wisatawan. Tabel dibawah ini menjelaskan tentang profil wisatawan Timur Tengah berdasarkan Sosio-demografi. 
National Conference of Creative Industry: Sustainable Tourism Industry for Economic Development Universitas Bunda Mulia, Jakarta, 5-6 September 2018 ISSN No: 
National Conference of Creative Industry:

Sustainable Tourism Industry for Economic Development

Universitas Bunda Mulia, Jakarta, 5-6 September 2018

Tabel 4.3

Data Penelitian Aspek Sosiodemografi

Pengumpulan data penelitian tentang profil wisatawan berdasarkan aspek sosiodemografi ini dilakukan melalui wawancara dengan 3 informan dalam waktu yang berbeda, pada periode Desember 2016 sampai dengan Januari 2017.

\begin{tabular}{|c|c|c|c|c|c|}
\hline $\begin{array}{c}\text { Fokus } \\
\text { Penelitian }\end{array}$ & \multicolumn{2}{|c|}{$\begin{array}{l}\text { Sub Fokus } \\
\text { Penelitian }\end{array}$} & Informan 1 & Informan 2 & Informan 3 \\
\hline \multirow[b]{2}{*}{ 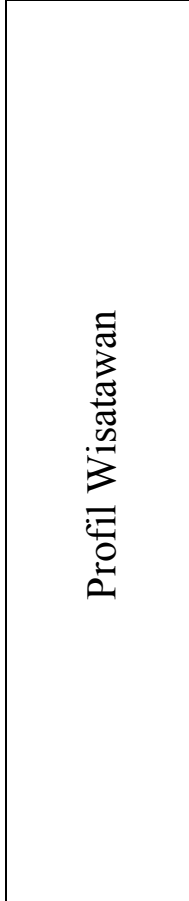 } & \multirow[b]{2}{*}{ 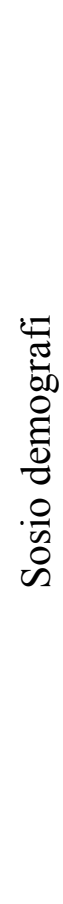 } & Usia & $\begin{array}{l}\text { Informan berasal dari Saudi Arabia } \\
\text { dengan rentan usia } 35 \text { - } 40 \text { tahun. }\end{array}$ & $\begin{array}{l}\text { Informan berasal dari Saudi Arabia } \\
\text { dengan rentan usia } 35 \text { - } 40 \text { tahun. }\end{array}$ & $\begin{array}{l}\text { Informan berasal dari Saudi Arabia, } \\
\text { dengan rentan usia } 50-55 \text { tahun }\end{array}$ \\
\hline & & $\begin{array}{l}\text { Latar } \\
\text { Belakang } \\
\text { Pendidika } \\
\mathrm{n}\end{array}$ & $\begin{array}{l}\text { Tergolong wisatawan yang } \\
\text { berpendidikan tinggi yang cenderung } \\
\text { memiliki minat untuk mendalami } \\
\text { sesuatu. }\end{array}$ & $\begin{array}{l}\text { Tergolong wisatawan yang } \\
\text { berpendidikan tinggi yang cenderung } \\
\text { memiliki minat untuk bersosialisasi } \\
\text { dengan penduduk setempat. memiliki } \\
\text { komunikasi dan kemampuan berbahasa } \\
\text { yang baik sehingga tidak terkendala } \\
\text { untuk berinteraksi dengan masyarakat } \\
\text { setempat. keluarga dari informan } 2 \\
\text { didominasi oleh perempuan sehingga } \\
\text { segala keputusan ada pada informan } 2 \text {. } \\
\text { Dengan memberikan contoh } \\
\text { komunikasi dan keterbukaan kepada } \\
\text { staff hotel membuat sanak family yang }\end{array}$ & $\begin{array}{l}\text { Tergolong wisatawan yang } \\
\text { berpendidikan tinggi karena memiliki } \\
\text { kemampuan bahasa inggris dengan } \\
\text { baik, dan memiliki minat untuk selalu } \\
\text { bersosialisasi di setiap daerah yang } \\
\text { dituju. kemampuan nya dalam } \\
\text { bersosialisasi dan pengetahuanya } \\
\text { tentang indonesia membuat informan } \\
\text { merasa indonesia seperti negara } \\
\text { keduanya namun Jika informan } \\
\text { melakukan traveling dengan keluarga } \\
\text { yang menjadi perantara } \\
\text { berkomunikasi adalah informan, }\end{array}$ \\
\hline
\end{tabular}


National Conference of Creative Industry:

Sustainable Tourism Industry for Economic Development

Universitas Bunda Mulia, Jakarta, 5-6 September 2018

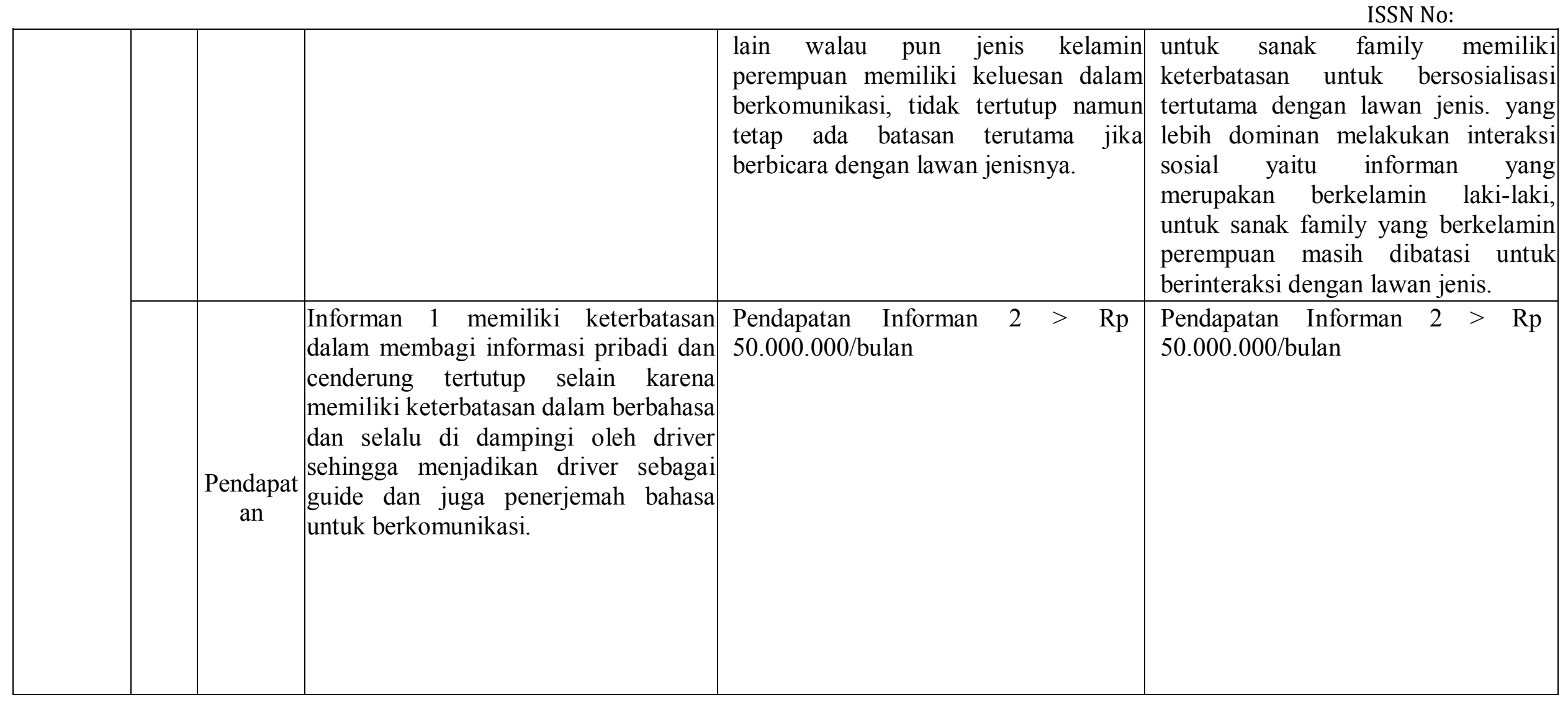




\section{National Conference of Creative Industry: Sustainable Tourism Industry for Economic Development}

Universitas Bunda Mulia, Jakarta, 5-6 September 2018

ISSN No:

Berdasrkan pada data penelitian yang tercantum dalam tabel 4.3 menyatakan bahwan Usia rata -rata Informan 1 dan informan 2 berkisar 35 - 40 tahun, sedangkan usia informan 3 bekisar 50 - 55 tahun. Ketiga informan tergolong memiliki latar belakang pendidikan yang cukup tinggi,ini tercermin dari sikap informan 1 walaupun kunjungan ke Bandung ini pertama kali namun tampak terlihat bahwa informan memiliki minat untuk mendalami sesuatu, ingin mengetahui keunikan di Bandung, karakteristik, serta nilai keunikan dari Bandung.

Sedangkan dari informan 2 memiliki minat untuk bersosialisasi dengan penduduk setempat.Memiliki kemampuan berbahasa yang baik sehingga tidak terkendala untuk berinteraksi dengan masyarakat setempat.Seringnya informan 2 melakukan kunjungan ke Bandung bersama keluarga yang di dominasi oleh kaum perempuan, namun segala keputusanada di informan 2. akan tetapi informan 2 tidak membatasi keluarganya untuk berinteraksi dengan yang lain terutama staff hotel berjenis kelamin perempuan, dengan memberikan contoh komunikasi yang baik dan keterbukaan terhadap staff hotel membuat keluarga lainnya walaupun berjenis kelamin perempuan juga memiliki keluesan dalam bersosialisasi dan memiliki bahasa inggris yang baik.

Informan 3 tergolong wisatawan yang berpendidikan tinggi karena memiliki kemampuan berbahasa inggris dengan baik, dan memiliki minat untuk selalu bersosialisasi di setiap daerah yang dituju. Kemampuannya dalam bersosialisasi dan pengetahuananya tentang indonesia membuat informan merasa Indonesia seperti negara keduannya. Namun jika informan melakukan traveling dengan keluarga yang menjadi perantara untuk berkomunikasi adalah informan.walaupun informan 2 memiliki keluesan untuk berinteraksi namun informan 2 tetap membatasi keluarganya untuk berinteraksi terlebih dengan lawan jenis.

Berkenaan dengan pendapatan yang tercantum dalam tabel 4.3 informan 1 memiliki keterbatasan dalam memberikan informasi pribadi dan cenderung tertutup selain karena memiliki keterbatasan dalam berbahasa dan selalu didampingi oleh driver yang juga menjadi guide dan penerjemah bahasa ketika berkomunikasi. Untuk pendapatan informan 2 dan 3 lebih dari Rp 50.000.000 per Bulan.

\subsubsection{Pembahasan Analisis Sosiodemography}

Menurut Ismiyati (2010:53) klasifikasi wisatawan dibedakan berdasarkan demografi, yaitu berdasarkan usia, bahwasanya wisatawan Timur Tengah tergolong kelompok Setengah Baya atau worldwar Babies, wisatawan setengah baya adalah wisatawan dewasa yang berusia 24 hingga 50 tahun yang sangat mapan dan memiliki ciri - ciri berpendapatan tinggi namun memiliki waktu wisata yang terbatas, umumnya masih memiliki kondisi fisik yang baik sehingga mampu melakukan kegiatan yang berpetualang, dalam pemilihan fasilitas dan pelayanan wisatawan setengah baya memiliki referensi tersendiri, minat terhadap alam dan budaya, dalam pengambilan keputusan untuk liburan sangat banyak faktor yang perlu di pertimbangkan. 


\section{National Conference of Creative Industry: \\ Sustainable Tourism Industry for Economic Development}

Universitas Bunda Mulia, Jakarta, 5-6 September 2018

ISSN No:

Berdasarkan data tersebut, wisatawan yang berpenghasilan tinggi cenderung memiliki tingkat pendidikan yang tinggi dengan jenis pekerjaan yang tetap dan memiliki rentan usia tertentu.

Gender merupakan hal yang cukup penting untuk untuk wisatawan Timur Tengah, karena terlihat dari data tersebut bahwasanya kegiatan berwisata didominasi oleh kaum pria, sedangkan seorang perempuan dalam berpergian harus didampingi oleh mukhrimnya.

\subsubsection{Data Penelitian Aspek Psikografi}

Selain karakteristik sosial dan demografi, faktor Psikografi wisatawan juga mempengaruhi tingkat dan pola perjalanan wisata.Tabel dibawah ini menjelaskan tentang tentang profil wisatawan Timur Tengah berdasarkan faktor Psikografi. 
National Conference of Creative Industry:

Sustainable Tourism Industry for Economic Development

Universitas Bunda Mulia, Jakarta, 5-6 September 2018

Tabel 4.4

Data Penelitian Aspek Psikografi

Pengumpulan data penelitian tentang profil wisatawan berdasarkan aspek psikografi ini dilakukan melalui wawancara dengan 3 informan dalam waktu yang berbeda, pada periode Desember 2016 sampai dengan Januari 2017.

\begin{tabular}{|c|c|c|c|c|c|}
\hline $\begin{array}{c}\text { Fokus } \\
\text { Penelitian }\end{array}$ & $\begin{array}{l}\text { Sub Fr } \\
\text { Peneli }\end{array}$ & & Informan 1 & Informan 2 & Informan 3 \\
\hline 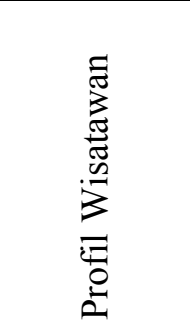 & Psikografi & $\begin{array}{l}\text { Kelas } \\
\text { Sosial }\end{array}$ & $\begin{array}{lcr}\text { Informan } & \text { merupakan salah } & \text { satu } \\
\text { pegawai } & \text { pemerintahan } & \text { yang } \\
\text { memiliki } & \text { keterbatasan } & \text { waktu } \\
\text { berlibur. } & & \end{array}$ & $\begin{array}{l}\text { Informan tergolong kelas menengah } \\
\text { karena bekerja dan memiliki suatu } \\
\text { jabatan diperusahaan exportir } \\
\text { Minyak. }\end{array}$ & $\begin{array}{lr}\text { Informan tergolong } & \text { kelas } \\
\text { menengah karena bekerja kurang } \\
\text { lebih } 35 \text { tahun disuatu perusahaan } \\
\text { sehingga mendapatkan sebuah } \\
\text { jabatan } & \text { sebagai } \\
\text { AccountingManager. }\end{array}$ \\
\hline
\end{tabular}


National Conference of Creative Industry:

Sustainable Tourism Industry for Economic Development

Universitas Bunda Mulia, Jakarta, 5-6 September 2018

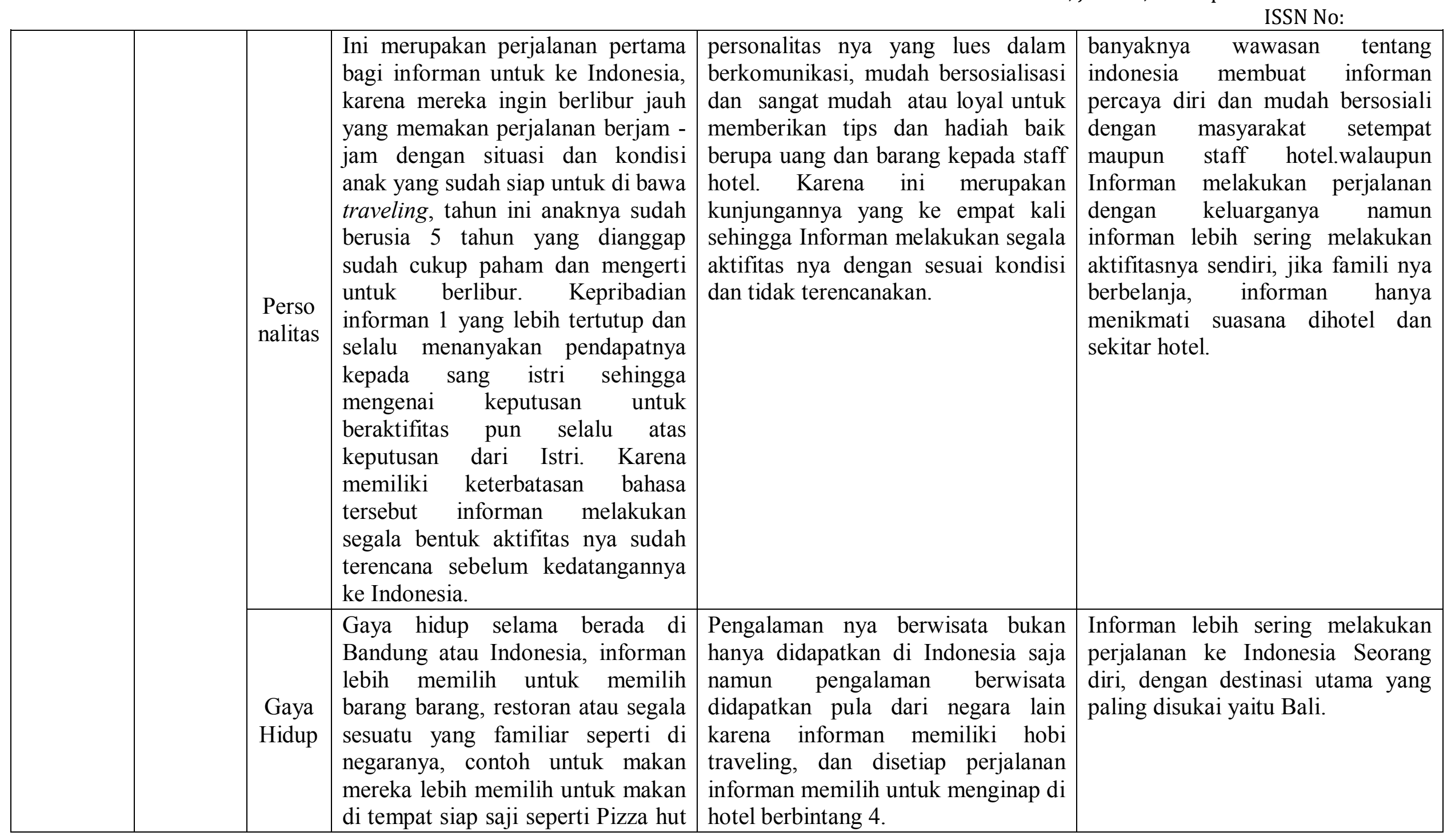


National Conference of Creative Industry:

Sustainable Tourism Industry for Economic Development

Universitas Bunda Mulia, Jakarta, 5-6 September 2018

\begin{tabular}{|l|l|l|l|l|}
\hline & & $\begin{array}{l}\text { dan McD karena brand tersebut } \\
\text { juga sudah sering mereka temui di } \\
\text { negaranya. }\end{array}$ & ISSN No: & \\
\hline
\end{tabular}




\section{National Conference of Creative Industry: Sustainable Tourism Industry for Economic Development}

Universitas Bunda Mulia, Jakarta, 5-6 September 2018

ISSN No:

Pemaparan data yang tertera pada tabel 4.4 menyatakan bahwa informan 1 merupakan pegawai pemerintahan yang memiliki keterbatasan waktu berlibur. Informan 2 tergolong kelas menengah karena bekerja dan memiliki suatu jabatan diperusahaan exportir minyak, sedangkan informan 3 juga tergolong kelas menengah karena sudah bekerja kurang lebih 35 tahun disuatu perusahaan swasta sehingga saat ini menduduki jabatan sebagai accounting manager.

Sedangkan secara personalitas pada tabel 4.4 dapat dilihat bahwa informan 1 memiliki kepribadian yang tertutup dan membatasi jawaban yang diberikan, untuk menjawab pertanyaan dari peneliti informan 1 selalu menanyakan pendapat kepada pasangannya sehingga ini mempengaruhi dalam pengambilan keputusan untuk beraktifitas. Informan 1 belum pernah melakukan perjalanan wisata, dikarenakan informan berfikir bahwa jika berwisata harus lah usia anak sudah memasuki masa anak - anak bukan balita, sekarang usia anak informan 1 berusia 5 tahun dan sudah dianggap cukup untuk dapat mengikuti orang tuanya untuk berwisata. Sehingga kunjungannya ke Indonesia ini merupakan untuk kali pertama nya informan 1 melakukan perjalanan wisata yang berjakarak cukup jauh. Kendala dalam perjalanan wisata yang dialami oleh informan 1 yaitu berbahasa, karena informan tidak cakap berbahasa Inggris sehingga informan melakukan segala bentuk aktifitas nya secara tersusun dan terencana jauh sebelum ke datangannya ke Indonesia.

Personalitas informan 2 yang memiliki keluesan dalam bersosialisasi, mudah berkomunikasi dan sangat loyal memberikan tips dan hadiah baik berupa uang dan barang kepada staff hotel dan masyarakat lokal yang dikenalinya. Karena ini merupakan kunjungan yang ke empat kalinya sehingga informan melakukan segala aktifitasnya tidak terencana, dan sesuai dengan kondisi saat tiba di daerah wisata.Begitupun dengan informan 3 karena memiliki wawasan tentang Indonesia yang cukup luas membuat informan lebih percaya diri dan mudah bersosialisasi dengan staff hotel maupun masyarakat setempat. Walaupun informan 3 melakukan perjalanan wisata ke Bandung dengan keluarganya namun informan lebih sering menghabiskan hari harinya dengan melakukan aktifitas sendiri, jika keluarga nya berbelanja informan 3 hanya menikmati suasana hotel dan jalan - jalan tanpa berkendaraan di area yang masih dekat dengan hotel.

Untuk gaya hidup informan 1 selama berada di Bandung atau Indonesia, informan lebih memilih restoran atau segala sesuatu yang familiar di negaranya. Contoh untuk restoran informan 1 lebih memilih untuk makan di tempat makan yang siap saji seperti Pizza Hut dan Mcdonald karena kedua brand tersebut juga sudah sering mereka temui di negaranya hal ini sangat berbeda dengan informan 2 dan 3.karena informan 2 dan informan 3 memiliki hobby berwisata membuat mereka lebih siap untuk berpetualang di Bandung. Informan 2 mendapatkan pengalamannya berwisata bukan hanya ia dapatkan di Indonesia tetapi di beberapa negara lain yang juga sering ia kunjungi untuk berlibur dan setiap perjalanan wisatanya informan memilih untuk menginap di hotel bintag 4 dan 5. Sedangkan informan 3 sangat menyukai Indonesia, tidak heran beberapa daerah seperti Jawa, Sumatera dan Bali sudah ia kunjungi. Setiap kali ada kesempatan untuk melakukan perjalanan wisata seorang diri, infoman 3 lebih memilih Bali sebagai destinasi utama. 


\section{National Conference of Creative Industry: Sustainable Tourism Industry for Economic Development \\ Universitas Bunda Mulia, Jakarta, 5-6 September 2018 \\ ISSN No:}

\subsubsection{Pebahasan Analisis Psikografi}

Berdasarkan analisa faktor psikografis ini dapat terlihat segmentasi pasar, dimana menurut Sumarwan "Analisa psikografi juga diartikan sebagai suatu riset konsumen yang menggambarkan segmen konsumen dalam hal kehidupannya, pekerjaan dan aktifitas lainnya".

Wisatawa Timur Tengah yang melakukan perjalanan wisata di Bandung tergolong wisatawan kelas menengah keatas, wisatawan Timur Tengah ini melakukan pemesanan akomodasi selama perjalanan wisatanya dalam rentan waktu 1 tahun hingga kurang dari 3 bukan sebelum keberangkatan.wisatawan Timur Tengah merupakan tipe wisatawan yang menyukai sesuatu yang penuh dengan kemewahan atau luxury goods, sebagian besar perjalanan wisata dilakukan bersama anggota keluarga,dan lebih memilih untuk melakukan perjalanan wisata ke suatu destinasi yang memiliki hubungan dengan islam. Sangat menyukai keindahan alam, kehijauan, dan udara yang sejuk.Karena sebagian besar wisatawan Timur Tengah adalah wisatawan keluarga untuk setiap aktifitasnya dilakukan pada siang hari, karena wisatawan keluarga tidak menyukai nightlife dan entertainment kecuali wisatawan muda.walaupun wisatawan Timur Tengah ini selalu berbicara dengan nada tinggi, kurang sabar, tidak suka di bantah dan wanitanya tidak berjabat tangan dengan seseorang yang diluar dari keluarganya namun wisatawan yang sangat loyal dalam memberikan tips maupun hadiah.

\subsubsection{Data Penelitian Berdasarkan Tipologi Wisatawan}

Tabel dibawah ini menjelaskan tentang tipologi wisatawan merupakan pendekatan sosiologi tentang wisatawan yang dikelompokkan menjadi 3 tipe wisatawan, yaitu : Tipe Allocentris, Tipe Psycocentris, dan Time Mid-Centris. 
National Conference of Creative Industry: Sustainable Tourism Industry for Economic Development Universitas Bunda Mulia, Jakarta, 5-6 September 2018 ISSN No: 
National Conference of Creative Industry:

Sustainable Tourism Industry for Economic Development

Universitas Bunda Mulia, Jakarta, 5-6 September 2018

Tabel 4.5

Data Penelitian Berdasarkan Tipologi Wisatawan

Pengumpulan data penelitian profil wisatawan yang dilihat berdasarkan tipologi wisatawan ini dilakukan melalui wawancara dengan 3 informan dalam waktu yang berbeda, pada periode Desember 2016 sampai dengan Januari 2017.

\begin{tabular}{|c|c|c|c|c|c|}
\hline $\begin{array}{c}\text { Fokus } \\
\text { Penelitian }\end{array}$ & \multicolumn{2}{|c|}{ Sub fokus penelitian } & Informan 1 & \multicolumn{2}{|r|}{ Informan 3} \\
\hline \multirow{3}{*}{ 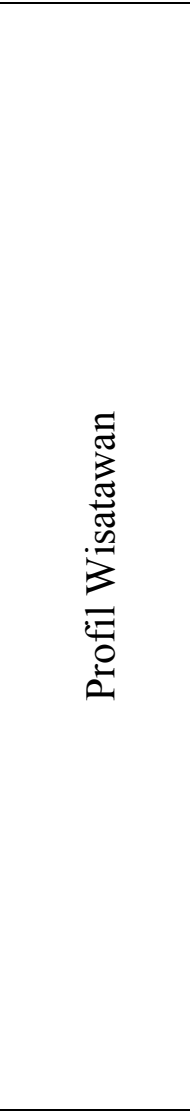 } & ${ }_{\mathbb{E}}^{\mathbb{E}}$ & Allocentric & $\begin{array}{l}\text { Karena ini } \text { merupakan } \\
\text { perjalanan wisata untuk kali } \\
\text { pertama, informan 1 tidak } \\
\text { memiliki keinginan untuk } \\
\text { berpetualang menemukan } \\
\text { sesuatu diluar yang orang lain } \\
\text { ketahui. }\end{array}$ & $\begin{array}{l}\text { Walaupun ini sudah perjalanan } \\
\text { wisata ke bandung untuk ke } 4 \\
\text { kali namun informan lebih } \\
\text { memilih untuk menginap, } \\
\text { restoran dan aktivitas yang } \\
\text { sudah pernah di lakukan. Tidak } \\
\text { mau mencoba sesuatu yang baru. }\end{array}$ & $\begin{array}{l}\text { Informan } 3 \text { sangan menyukai } \\
\text { aktifitas berpetualangan dan } \\
\text { mendapatka sesuatu yang baru. Ini } \\
\text { dapat tercermin dengan } \\
\text { keinginannya untuk menjelajahi } \\
\text { daerah - daerah yang ada di } \\
\text { Indonesia. namun untuk keperluan } \\
\text { mendasar seperti akomodasi dan } \\
\text { restoran informan } 3 \text { lebih memilih } \\
\text { untuk berada di tempat yang sama }\end{array}$ \\
\hline & 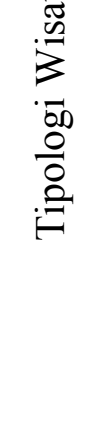 & Psychocentric & $\begin{array}{lr}\text { Sebelum kedatangannya ke } \\
\text { Bandung, informan 1 sudah } \\
\text { memastikan baik itu } \\
\text { akomodasi, transportasi dan } \\
\text { itinerary sesuai dengan yang di } \\
\text { persiapkan oleh sanak } \\
\text { familinya yang memang sudah } \\
\text { beberapa kali melakukan } \\
\text { kunjungan wisata ke Bandung }\end{array}$ & $\begin{array}{l}\text { Setiap kali berkunjung ke } \\
\text { Bandung, informan selalu } \\
\text { menginap di hotel yang sama, } \\
\text { memilih restoran dan menu yang } \\
\text { sama serta mengunjungi daya } \\
\text { tarik wisata yang sudah pernah } \\
\text { di kunjungi. }\end{array}$ & $\begin{array}{l}\text { Untuk kebutuhan mendasan } \\
\text { seperti hotel, transportasi serta } \\
\text { restoran. Informan } 3 \text { tidak ingin } \\
\text { mencoba sesuatu yang baru. Dia } \\
\text { akan tetap menginap di hotel yang } \\
\text { dulu, akan mengunjungi restoran } \\
\text { dan memesan menu favorit yang } \\
\text { iya sukai selama berkunjung di } \\
\text { Bandung. }\end{array}$ \\
\hline & & Mid-centric & $\begin{array}{l}\text { Menurut informan } 1 \text {, mungkin } \\
\text { jika memiliki kesempatan } \\
\text { kembali lagi ke Bandung, ia } \\
\text { akan mencoba untuk }\end{array}$ & $\begin{array}{l}\text { Walaupun informan } 2 \text { sangat } \\
\text { mempertahankan pilihannya } \\
\text { untuk tidak mencoba sesuatu } \\
\text { yang baru namun untuk jadwal }\end{array}$ & $\begin{array}{l}\text { Informan } 3 \text { memiliki rasa ingin } \\
\text { tahu yang sangat tinggi, dan } \\
\text { keberaniannya untuk menjelajahi } \\
\text { sesuatu yang baru. Namun ada }\end{array}$ \\
\hline
\end{tabular}


National Conference of Creative Industry:

Sustainable Tourism Industry for Economic Development

Universitas Bunda Mulia, Jakarta, 5-6 September 2018

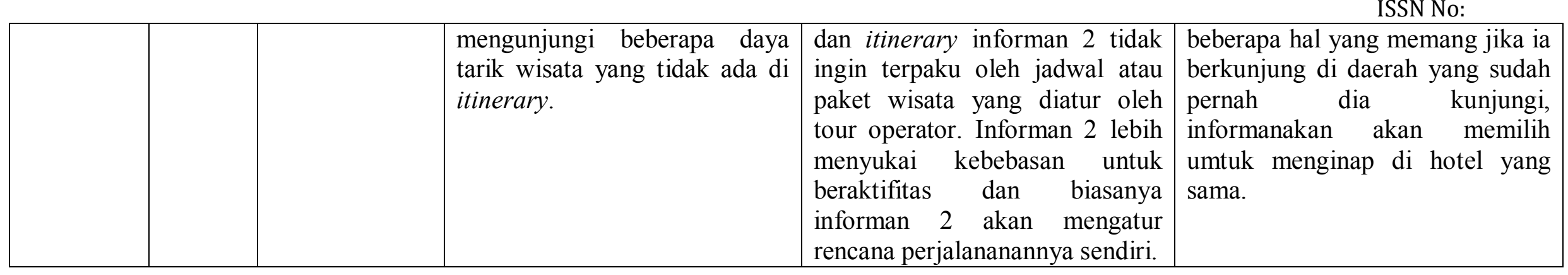




\section{National Conference of Creative Industry: Sustainable Tourism Industry for Economic Development}

Universitas Bunda Mulia, Jakarta, 5-6 September 2018

ISSN No:

Pada tabel 4.5 yakni berkenaan dengan data penelitian yang berdasarkan pada aspek tipologi wisatawan bahwasanya untuk informan 1 ini merupakan perjalanan wisata untuk yang pertama, dimana informan 1 tidak memiliki keinginan untuk berpetualang menemukan sesuatu diluar yang orang lain sarankan kepadanya. Berbeda dengan informan 2 dan 3, dimana informan 2 walaupun ini sudah perjalanan wisata ke bandung untuk ke 4 kali namun informan lebih memilih untuk menginap, restoran dan aktivitas yang sudah pernah di lakukan. tidak mau mencoba sesuatu yang baru. Sedangkan informan 3 walau sangat menyukai aktifitas berpetualangan dan ingin mendapatkan sesuatu yang baru yang tercermin dengan keinginannya untuk menjelajahi daerah - daerah yang ada di Indonesia.Namun sama halnya dengan informan 2 untuk keperluan mendasar seperti akomodasi dan restoran informan 3 lebih memilih untuk berada di tempat yang sama.

Sebelum kedatangannya ke Bandung, informan 1 sudah memastikan baik itu akomodasi, transportasi dan itinerary sesuai dengan yang di persiapkan oleh sanak familinya yang memang sudah beberapa kali melakukan kunjungan wisata ke Bandung. Sedangkan informan 2 setiap kali kunjunganya ke Bandung dia selalu menginap di hotel yang sama, memilih restoran dan menu yang sama serta mengunjungi daya tarik wisata yang sudah pernah di kunjungi dan dengan infomran 3 yaitu untuk kebutuhan mendasar seperti hotel, transportasi serta restoran. Informan 3 tidak ingin mencoba sesuatu yang baru. Dia akan tetap menginap di hotel yang dulu, akan mengunjungi restaurannt dan memesan menu favorit yang iya sukai selama berkunjung di Bandung.

Menurut informan 1, mungkin jika memiliki kesempatan kembali lagi ke Bandung, ia akan mencoba untuk mengunjungi beberapa daya tarik wisata yang tidak ada di itinerary.w alaupun informan 2 sangat mempertahankan pilihannya untuk tidak mencoba sesuatu yang baru namun untuk jadwal dan itinerary informan 2 tidak ingin terpaku oleh jadwal atau paket wisata yang diatur oleh tour operator. Informan 2 lebih menyukai kebebasan untuk beraktifitas dan biasanya informan 2 akan mengatur rencana perjalananannya sendiri. Informan 3 memiliki rasa ingin tahu yang sangat tinggi, dan keberaniannya untuk menjelajahi sesuatu yang baru. Namun ada beberapa hal yang memang jika ia berkunjung di daerah yang sudah pernah dia kunjungi,informanakan akan memilih umtuk menginap di hotel yang sama.

\subsubsection{Pembahasan Tipologi Wisatawan}

Menurut Plog, S wisatawan dapat diklasifikasian menjadi 3 bagian yaitu; tipe allocentric, tipe psychocentric dan tipe mid - centric.Tipologi wisatwan ini menjadi dasar untuk perencanaan pola perjalanan wisata, maka sangat penting untuk diketahui agar mampu mengembangkan objek wisata yang sesuai dengan segmentasi pasar.

Segmentasi pasar pada penelitian ini yaitu wisatawan Timur Tengah tergolong kepada tipe mid - centric yaitu wisatawan yang berada diatara tipe allocentric dan psychocentric atau lebih tepatnya near psychocentric ke mid - centric. Walaupun wisatawan Timur Tengah ini hanya ingin melakukan perjalanan wisata dengan mengunjungi tujuan wisata yang sudah pernah dikunjungi, yang dianggap memiliki standar yang sesuai namun untuk perihal pengaturan perjalanan seperti program dan 


\section{National Conference of Creative Industry: \\ Sustainable Tourism Industry for Economic Development}

Universitas Bunda Mulia, Jakarta, 5-6 September 2018

ISSN No:

itinerary, untuk wisatawan Timur Tengah tidak akan akan memiliki kepastian waktu dan program.

\subsection{Hasil Analisis dan Pembahasan Pada Aspek Motivasi}

Selain perlu adanya profil wisatwan, untuk pembentukan suatu pola perjalanan yang terpadu juga bisa dilihat dari motivasi wisatawan. Pada tabel di bawah ini akan menjelaskan tentang motivasi wisatawan yang terbagi kedalam beberapa faktor, seperti tingkat kebutuhan, kategori motivasi, faktor pendorong dan faktor penarik.

\subsubsection{Data Penelitian Berdasarkan Tingkat Kebutuhan}

Motivasi wisatawan berdasarkan tingkat kebutuhan terbagi menjadi 5 bagian, yaitu: kebutuhan dasar atau fisiologis (Physiological Needs), kebutuhan terhadap rasa aman (Safety Needs), kebutuhan sosial (Social Needs), kebutuhan untuk di hargai (EsteemNeeds) dan kebutuhan aktualisasi diri (self - actualization). 
National Conference of Creative Industry:

Sustainable Tourism Industry for Economic Development

Universitas Bunda Mulia, Jakarta, 5-6 September 2018

Tabel 4.6

ISSN No:

Data Penelitian Berdasarkan Tingkat Kebutuhan.

Pengumpulan data penelitian pada aspek motivasi yang berdasarkan tingkat kebutuhan ini dilakukan melalui wawancara dengan

3 informan dalam waktu yang berbeda, pada periode Desember 2016 sampai dengan Januari 2017.

\begin{tabular}{|c|c|c|c|c|c|}
\hline $\begin{array}{c}\text { Fokus } \\
\text { Penelitian }\end{array}$ & & $\begin{array}{l}\text { Sub fokus } \\
\text { penelitian }\end{array}$ & Informan 1 & Informan 2 & Informan 3 \\
\hline \multirow[t]{2}{*}{ 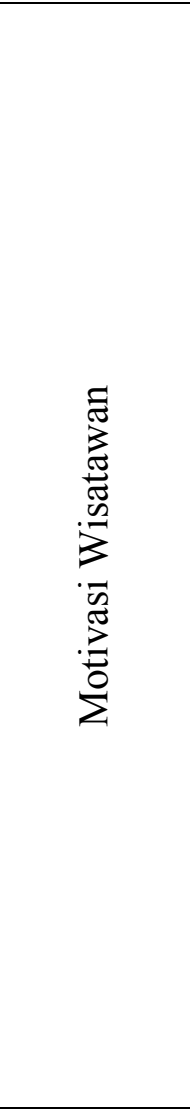 } & \multirow[t]{2}{*}{ 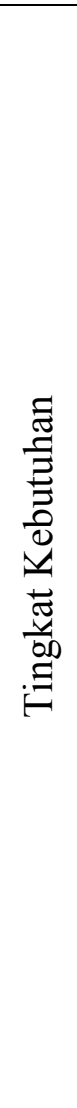 } & $\begin{array}{c}\text { Physiological } \\
\text { Needs }\end{array}$ & $\begin{array}{l}\text { Atas dasar informasi dari } \\
\text { keluarganya bahwa dengan } \\
\text { berkunjung kebandung kebutuhan } \\
\text { psikologi atau physiological needs } \\
\text { nya akan terpenuhi, di Bandung } \\
\text { sangat mudah mendapatkan } \\
\text { makanan yang Halal, Hotel yang } \\
\text { berkelas bintang } 4 \text { dengan harga } \\
\text { yang sesuai. }\end{array}$ & $\begin{array}{l}\text { Informan } \text { sangat memahami } \\
\text { bahwa dengan berkunjung ke } \\
\text { Bandung kebutuhan akan } \\
\text { psikologi dan kebutuhan sosial } \\
\text { akan terpenuhi, sehingga } \\
\text { informan merasa bahwa Bandung } \\
\text { rumah keduanya } r \text { setelah } \\
\text { negaranya sendiri. Terlebih } \\
\text { dengan Bandung merupakan } \\
\text { mayoritas pendudukanya } \\
\text { memeluk agama Islam sehingga } \\
\text { informan tidak merasa khawatir } \\
\text { untuk menemukan makanan atau } \\
\text { restoran yang halal, dan } \\
\text { akomodasi yang sesuai dengan } \\
\text { yang di inginkan oleh informan }\end{array}$ & $\begin{array}{l}\text { Informan merasa Indonesia } \\
\text { merupakan nergara yang layak } \\
\text { dikunjungi oleh wisatawan asing } \\
\text { terutama wisatawan dari Timur } \\
\text { Tengah, karena mayoritas } \\
\text { penduduk beraga Islam sehingga } \\
\text { kebutuhan psikologi sudah pastia } \\
\text { akan terpenuhi. }\end{array}$ \\
\hline & & Safety Needs & $\begin{array}{l}\text { secara kebutuhan dasar } \\
\text { SafetyNeeds,informan melakukan } \\
\text { perjalanan wisata sudah di atur } \\
\text { atau ditentukan oleh sanak famili } \\
\text { nya yang memang sudah pernah } \\
\text { datang ke Indonesia sebelumnya } \\
\text { karena ini merupakan pengalaman }\end{array}$ & $\begin{array}{l}\text { Informan merasa aman untuk } \\
\text { berlibur di Bandung, karena } \\
\text { informan sudah berkunjung ke } 4 \\
\text { kalinya. Selain itu karena } \\
\text { Bandung merupakan destinasi } \\
\text { tujuan yang aman, informan } \\
\text { merekomendasikan kepada kaka }\end{array}$ & $\begin{array}{l}\text { Indonesia memiliki keamanan } \\
\text { yang baik terutama di pintu masuk } \\
\text { yaitu bandara. Informan sangat } \\
\text { berterimakasih kepada para } \\
\text { pegawai imigrasi yang ramah dan } \\
\text { sangat membantu para wisatawan. }\end{array}$ \\
\hline
\end{tabular}


National Conference of Creative Industry:

Sustainable Tourism Industry for Economic Development

Universitas Bunda Mulia, Jakarta, 5-6 September 2018

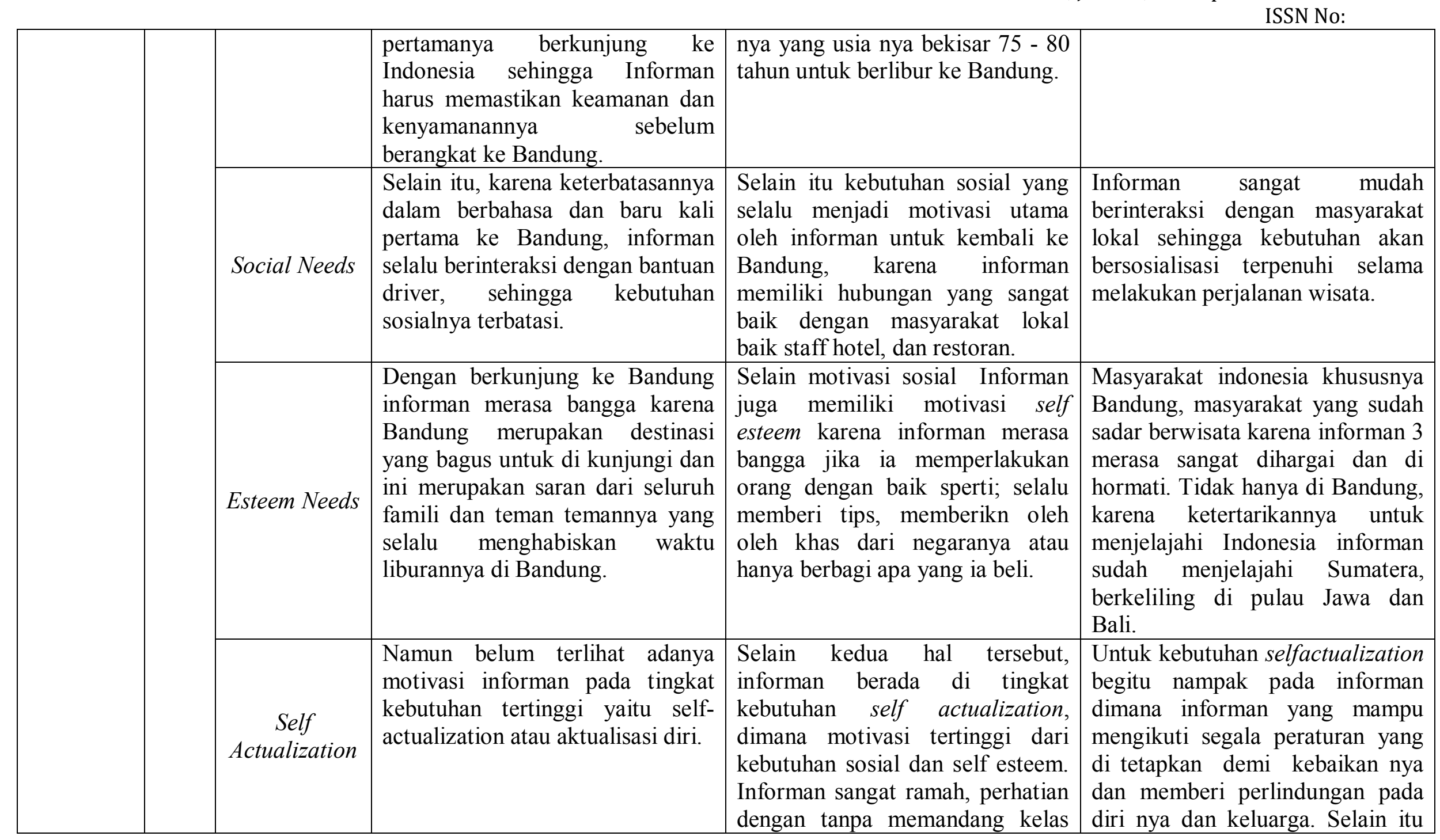


National Conference of Creative Industry:

Sustainable Tourism Industry for Economic Development

Universitas Bunda Mulia, Jakarta, 5-6 September 2018

ISSN No:

\begin{tabular}{|l|l|l|l|l|}
\hline & & & $\begin{array}{l}\text { sosial, warna kulit, usia dan informan sangat rendah diri untuk } \\
\text { sangat menghargai serta rendah berbagi kepada masyarakat lokal } \\
\text { hati. Informan yang penuh terutama staff yang melayaninya. } \\
\text { kesederhanaaan dan bertingkah } \\
\text { laku dengan spontan dan memiliki } \\
\text { kemampuan beradaptasi dengan } \\
\text { mudah dan cepat. }\end{array}$ \\
\hline
\end{tabular}




\section{National Conference of Creative Industry: Sustainable Tourism Industry for Economic Development}

Universitas Bunda Mulia, Jakarta, 5-6 September 2018

ISSN No:

Motivasi wisatawan berdasarkan tingkat kebutuhan yang paling mendasar yaitu kebutuhan dasar atau fisiologis informan selama di Bandung sedikit memiliki kesamaan. Untuk informan 1 karena ini merupakan kunjungan kali pertamanya ke Bandung motivasi kebutruhan dasar selama berada di Bandung merupakan atas dasar informasi dari keluarganya yang sudah berkunjung terlebih dahulu bahwa dengan berkunnjung ke Bandung kebutuhan dasar akan terpenuhi, karena di Bandung akan sangat mudah mendapatkan makanan yang halal, dan hotel berbintang 4 dengan harga yang sesuai.

Informan 2 sangat memahami bahwa dengan berkunjung ke Bandung kebutuhan dasar dan kebutuhan sosial akan terpenuhi, sehingga informan merasa bahwa Bandung merupakan rumah keduanya setelah negaranya sendiri. Terlebih dengan Bandung yang merupakan mayoritas penduduknya beragama islam sehingga informan tidak merasa khawatir untuk menemukan makanan atau restoran halal dan akomodasi yang sesuai dengan yang di inginkan oleh informan.

Sama halnya dengan Informan 3 yang merasa bahwa Indonesia merupakan negara yang layak dikunjungi oleh wisatawan asing terutama wisatawan dari Timur Tengah, karena mayoritas penduduk beraga Islam sehingga kebutuhan dasar sudah dipastikan akan terpenuhi dengan baik.

Tingkat kebutuhan akan rasa aman untuk informan 1dalam melakukan perjalanan wisatanya sudah di atur atau di tentukan oleh keluarganya yanag memang sudah pernah berkunjung ke Bandung,karena ini merupakan perjalanan wisata untuk pertama kalinya sehingga informan harus benar - benar memastikan dan mengikuti saran yang di berikan oleh keluarganya. Dan menyiapkan perjalanan wisatanya ini jauh sebelum kedatangannya ke Bandung.

Berbeda dengan informan 2 dan informan 3, informan 2 merasa sanggat aman untuk berlibur dan melakukan perjalanan wisata di Bandung dapat dilihat sangat seringnya informan 2 berwisata di Bandung. Selain itu menurut informan 2 Bandung merupakan destinasi wisata yang aman, sehingga informan merekomendasikan kepada kaka nya yang sudah berusia bekisar 75 - 80 tahun untuk berlibur ke Bandung.Sedangkan menurut informan 3 Indonesia memiliki keamanan yang baik terutama di pintu masuk yaitu bandara, informan sangat berterimakasih dan sangat terkesan kepada para pegawai imigrasi yang ramah dan sangat membatu para wisatawan.

Adanya sedikit keterbatasan dalam berbahasa bagi informan 1 menjadi kendala untuk memenuhi kebutuhan sosial, karena selama perjalanan wisatanya di Bandung informan 1 berinteraksi dengan bantuan driver yang juga merangkap sebagai guide dan penerjemah.Hal ini sangat nampak perbedaannya dengan informan 2 dan informan 3.

Kebutuhan sosial merupakan motivasi utama informan 2 untuk kembali berkunjung ke Bandung, karena informan memiliki hubungan yang sangat baik dengan masyarakat lokal dan beberapa staff hotel dan restoran. Begitupun dengan informan 3 yang sangat mudah berinteraksi dengan masyarakat lokal sehingga kebutuhan akan sosial merasa sangat terpenuhi selama perjalanan wisatanya di Bandung. 


\section{National Conference of Creative Industry: Sustainable Tourism Industry for Economic Development}

Universitas Bunda Mulia, Jakarta, 5-6 September 2018

ISSN No:

Ketiga informan merasa kebutuhan akan di hargai selama perjalanan di Bandung terpenuhi, selain karena bandung di dominasi oleh masyarakat yang beragama Islam juga Bandung memiliki masyarakat yang selalu siap untuk membantu dan ramah kepada wisatawan. Selain itu dengan berkunjung ke Bandung informan 1 merasa bangga karena Bandung merupakan destinasi yang memiliki ke indahan alam yang menarik juga sudah banyak si kunjungi oleh wisatawan Timur Tengah dan ini merupakan hasil rekomendasi dari keluarga dan kerabatnya yang selalu menghabiskan waktu liburannya di Bandung.

Informan 2 selain termotivasi oleh kebutuhan motivasi sosial, kebutuhan akan di hargai juga menjadi hal yang utama, karena informan memiliki rasa bangga dan dihargai jika apapun yang diberikan olehnya disukai dan di terima oleh masyarakat lokal, sehingga informan 2 selalu memberikan tips, memberikan buah tangan dari negaranya atau hanya berbagi apa yang ia beli. Begitupun dengan Informan 3, menurut informan 3 masyarakat indonesia khususnya Bandung, masyarakat yang sudah sadar wisata karena informan 3 merasa sangat dihargai dan di hormati. Tidak hanya di Bandung, karena ketertarikannya untuk menjelajahi Indonesia informan sudah menjelajahi Sumatera, berkeliling di pulau Jawa dan Bali.

Tingkat kebutuhan yang tertinggi yaitu kebutuhan aktualisasi diri belum nampak terlihat dari informan 1, berbeda dengan informan 2 dan informan 3 .informan 2 yang memiliki personaliti sangat ramah, penuh perhatian dengan tidak memandang kelas sosial, warna kulit, usia dan sangat menghargai orang lain, rendah hati. Informan yang berpenampilan penuh dengan kesederhanaan dan bertingkah laku dengan sopan dan memiliki kemampuan beradaptasi dengan mudah.Begitupun dengan informan 3 selain memiliki sifat yang baik dan selalu berbagi, informan 3 juga mampu mengikuti segala peraturan yang di tetapkan demi kebaikannya dan memberi perlindungan pada dirinya dan keluarga.

\subsubsection{Pembahasan Analisis Berdasarkan Tingkat Kebutuhan}

Berdasarkan teori motivasi dari maslow tentang Hierarchy of human needs atau tingkat kebutuhan yang terdiri dari lima tingkatan kebutuhan seseorang yaitu ; kebutuhan dasar atau fisiologis (Physiological Needs), Bandung merupakan salah satu daerah wisata yang baik di jawa barat, sehingga kebutuhan dasar wisatawan untuk melakukan penjalanannya di Bandung akan terpenuhi.untuk wisatawan Timur Tengah kebuthan akan akomodasi yang memiliki pelayanan yang baik, restaurat dan menu yang halal. Setelah kebuthan dasar pada suatu daerah wisata terpenuhi, wisatawan akan mulai memperhatikan kebuthan akan rasa aman. kebutuhan akan rasa aman (Safety Needs) di Bandung juga didapatkan oleh wisatawan Timur Tengah karena wisatawan Timur Tengah merasa keramahan dan kesiapan untuk selalu membantu wisatawan membuat wisatawan Timur Tengah selalu kembali untuk menghabiskan waktu liburnya di Bandung. kebutuhan sosial (Social Needs) akan timbul jika kebutuhan akan rasa aman terpenuhi, wisatwan Timur Tengah meyukai pelayanan yang persifat personal touching, walaupun sifatnya personal namun wisatawan Timur Tengah sangat mudah untuk bersosialisasi, jika mereka merasa dilayani dengan baik maka wisatan Timur Tengah pun akan lebih baik dan loyal ke 


\section{National Conference of Creative Industry: \\ Sustainable Tourism Industry for Economic Development}

Universitas Bunda Mulia, Jakarta, 5-6 September 2018

ISSN No:

pada staff yang melayaninya. Kebutuhan untuk di hargai (Esteem Needs) akan timbul ketika kebutuhan sosialisasi terpenuhi,dengan menginginkan pelayanan yang maksimal dan personal touching wisatawan Timur Tengah merasa di Hargai. dan kebutuhan aktualisasi diri (self - actualization) akan di capai ketika wisatawan telah merasa puas akan dirinya, puas akan apa yang di dapatkan selama perjalanan wisatanya di Bandung, sehingga jika seorang wisatawan sudah ada di tahap tertinggi ini, akan menjadi sangat loyal dan akan menjadi repeater atau pelanggan setia yang akan kembali jika waktu libur tiba. Sehingga wisatawan Timur Tengah yang melakukan perjalanan wisata di Bandung merasa kebutuhannya terpenuhi dari kebtuhan dasar sampai dengan ketingkat tertinggi yaitu kebutuhan aktualisasi diri (self-actualization).

\subsubsection{Data Penelitian Berdasarkan Kategori Motivasi}

Selain motivasi wisatawan berdasarkan tingkat kebutuhan, beberapa kategori motivasi juga dijadikan acuan untuk membuat pola perjalanan yang lebih terpadu, kategori motivasi wisataqswan yang terdiri atas ; motivasi fisik, motivasi budaya, motivasi internal dan motivasi untuk mendapatkan penghargaan dan status. 
National Conference of Creative Industry:

Sustainable Tourism Industry for Economic Development

Universitas Bunda Mulia, Jakarta, 5-6 September 2018

Tabel 4.7

Data Penelitian Berdasarkan Kategori Motivasi

Pengumpulan data penelitian pada aspek motivasi berdasarkan kategori motivasi ini dilakukan melalui wawancara dengan 3 informan dalam waktu yang berbeda, pada periode Desember 2016 sampai dengan Januari 2017.

\begin{tabular}{|c|c|c|c|c|c|}
\hline $\begin{array}{c}\text { Fokus } \\
\text { Penelitian }\end{array}$ & \multicolumn{2}{|c|}{$\begin{array}{l}\text { Sub Fokus } \\
\text { Penelitian }\end{array}$} & Informan 1 & Informan 2 & Informan 3 \\
\hline \multirow[t]{2}{*}{ 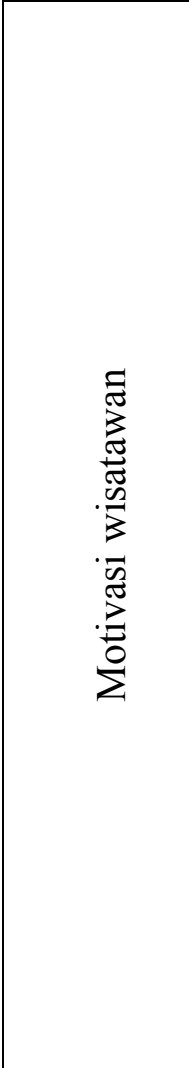 } & \multirow[t]{2}{*}{ 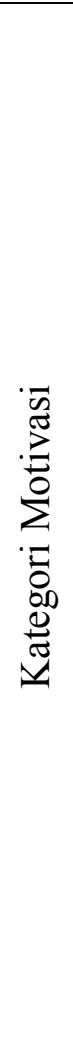 } & $\begin{array}{c}\text { Physical } \\
\text { Motivation }\end{array}$ & $\begin{array}{l}\text { Dengan kategori motivasi yaitu } \\
\text { physical motivation dimana } \\
\text { informan melakukan perjalanan } \\
\text { untuk bersantai bersama } \\
\text { keluarga. Selain itu Bandung } \\
\text { memiliki daya tarik wisata yang } \\
\text { bisa untuk dilakukan bersama } \\
\text { keluarga. }\end{array}$ & $\begin{array}{l}\text { Dengan berkunjung nya informan } \\
\text { di Bandung berkali - kali terutama } \\
\text { untuk relaksasi, bersantai dengan } \\
\text { nyaman dan aman. }\end{array}$ & $\begin{array}{l}\text { Informan ke tiga menjelaskan } \\
\text { bahwa dirinya adalah salah satu } \\
\text { wisatawan Timur Tengah yang } \\
\text { cukup sering mengunjungi } \\
\text { Indonesia. Menurut informan, } \\
\text { Bandung memang dapat menjadi } \\
\text { salah satu destinasi untuk } \\
\text { menjawab motivasi secara fisikal, } \\
\text { seperti tempat untuk berelaksasi } \\
\text { dan bersantai namun Bandung } \\
\text { belum dapat menjadi destinasi yang } \\
\text { utama dalam memenuhi motivasi } \\
\text { tersebut karena informan sendiri } \\
\text { lebih memilih Bali. }\end{array}$ \\
\hline & & $\begin{array}{c}\text { Cultural } \\
\text { Motivation }\end{array}$ & $\begin{array}{l}\text { informan ingin mengetahui } \\
\text { masyarakat dan kebudayaan } \\
\text { Indonesia karena ini merupakan } \\
\text { kunjungan pertamanya maka } \\
\text { informan ingin mengetahui } \\
\text { bagaimana perkembangan negara } \\
\text { yang mayoritas penduduknya } \\
\text { beraga Islam. }\end{array}$ & $\begin{array}{l}\text { karena informan merasa Bandung } \\
\text { merupakan rumah kedua, dimana } \\
\text { dia mendapatkan kenyamanan, } \\
\text { kebahagiaan dan juga dapat } \\
\text { mengenal budaya Bandung yang } \\
\text { ramahdan sopan. }\end{array}$ & $\begin{array}{l}\text { Begitu pula dengan motivasi secara } \\
\text { kebudayaan, informan lebih } \\
\text { memilih Bali untuk memenuhi } \\
\text { hasrat tersebut karena dianggap } \\
\text { sebagai destinasi dengan } \\
\text { lingkungan yang sangat kental } \\
\text { dalam hal kebudayaan. }\end{array}$ \\
\hline
\end{tabular}


National Conference of Creative Industry:

Sustainable Tourism Industry for Economic Development

Universitas Bunda Mulia, Jakarta, 5-6 September 2018

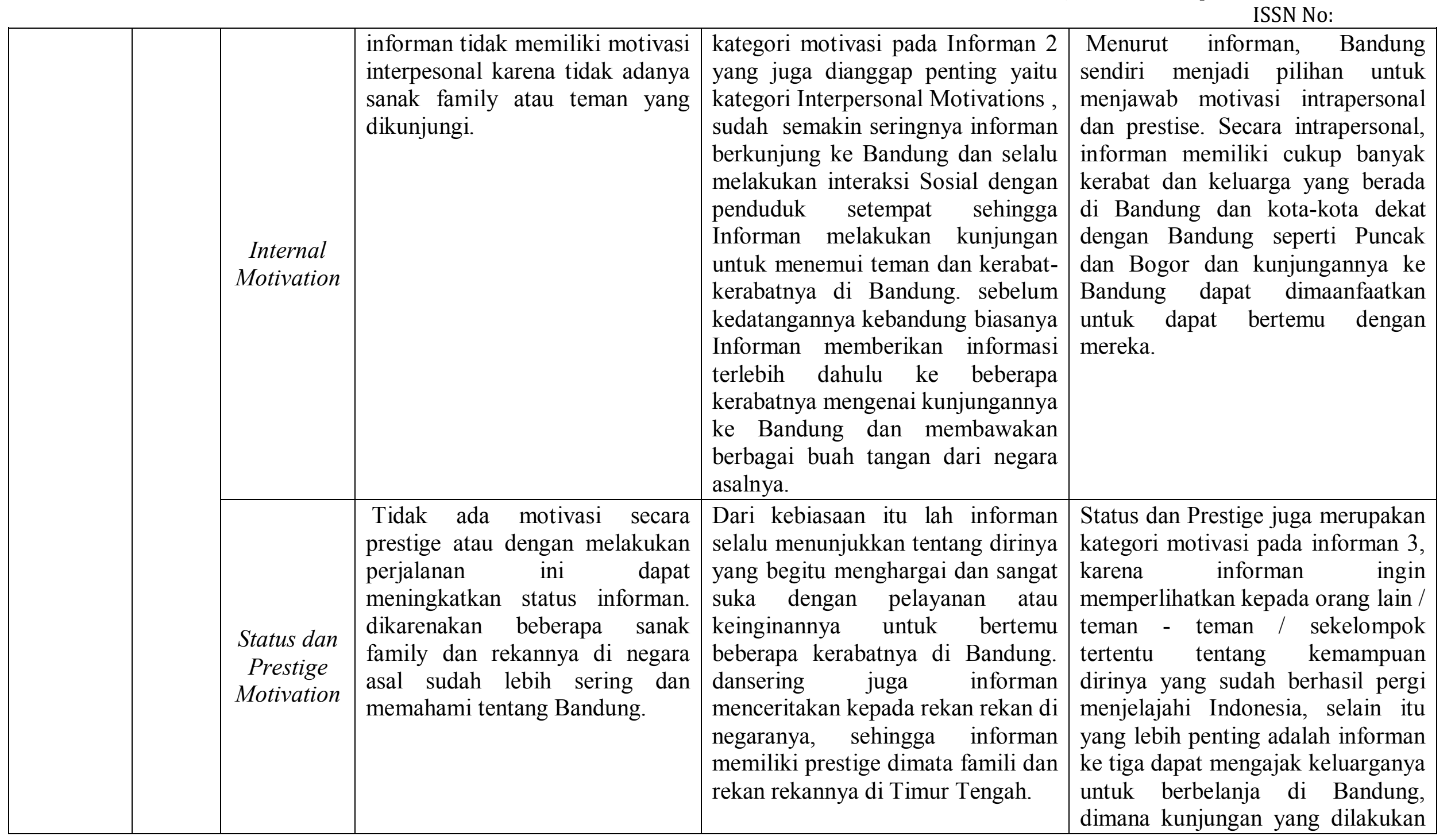


National Conference of Creative Industry:

Sustainable Tourism Industry for Economic Development

Universitas Bunda Mulia, Jakarta, 5-6 September 2018

ISSN No:

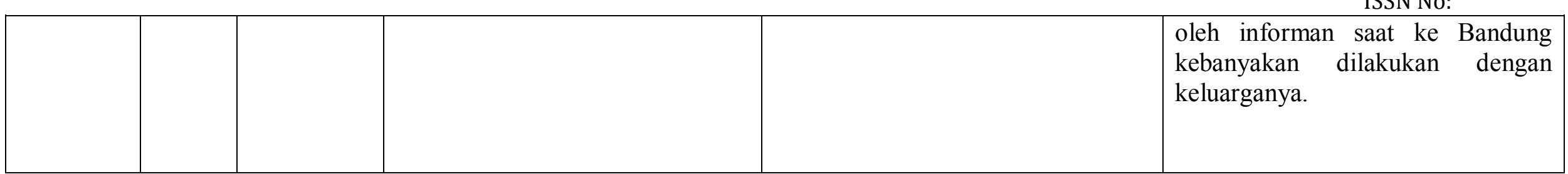




\section{National Conference of Creative Industry: Sustainable Tourism Industry for Economic Development}

Universitas Bunda Mulia, Jakarta, 5-6 September 2018

ISSN No:

Berdasarkan data penelitian yang tertera pada tabel 4.7 menyatakan bahwa Informan 1 dan informan 2 memiliki kesamaan dalam Physical motivasi, informan 1 dan informan 2 dalam melakukan perjalanan wisata ke Bandung dengan motivasi untuk relaksasi, menghabiskan waktu untuk bersantai bersama keluarga. Namun berbeda dengan informan 3, menurut informan 3 Bandung merupakan salah satu destinasi wisata yang cukup baik, banyaknya tempat untuk relaksasi dan bersantai namun informan 3 tidak menjadikan Bandung sebagai destinasi utama untuk itu, informan lebih memilih Bali sebagai destinasi utama untuk bersantai dan berelaksasi.

Walaupun ini merupakan kunjungan kali pertama informan 1 ke Bandung, namun informan termotivasi untuk mengetahui masyarakat Indonesia khususnya Bandung karena Bandung merupakan masyarakat yang berpenduduk dengan mayoritas muslim. Berbeda dengan informan 2 dan informan 3 dimana mereka sudah berulangkali mengunjungi Bandung, dimana kedua informan tersebut merasa nyaman, bahagia dan sangat menyukai budaya masyarakat local yang ramah dan terbuka terhadap turis mancanegara.

Informan 1 tidak memiliki internal motivation karena tidak adanya keluarga dan kerabat yang dikunjungi, namun untuk informan 2 mengganggap bahwa internal motivation merupakan hal yang penting karena sudah semakin seringnya berkunjung ke Bandung dan selalu melakukan interaksi social dengan penduduk setempat sehingga informan melakukan kunjungan untuk menemui teman dan kerabat kerabatnya di Bandung. Sebelum kedatangannya ke Bandung biasanya informan memberikan informasi terlebih dahulu ke beberapa kerabatnya mengenai kedatangannya ke Bandung dan membawakan berbagai buah tangan dari Negara asalnya.

Begitupun dengan informan 3, informal memiliki cukup banyak kerabat dan keluarga yang berada di Bandung dan kota - kota lainnya seperti : Puncak dan Bogor, sehingga kunjungannya ke Indonesia di manfaatkan untuk bertemu dengan mereka.

Motivasi untuk mendapatkan penghargaan dan status belum terlihat pada informan 1, dikarenakan beberapa keluarga dan rekannya sudah lebih dahulu dan lebih sering melakukan perjalanan wisata di Indonesia dan Bandung dan sudah lebih memahami tentang Indonesia.Namun untuk informan 2 yang selalu menunjukkan tentang dirinya yang begitu menghargai, dan selalu berkeinginan untuk bertemu beberapa rekannya di Bandung. Selain itu informan 2 juga selalu menceritakan kepada keluarga lainnya dan kerabat - kerabat di Negara asalnya, sehingga informan memiliki prestige dimata keluarga dan rekan - rekannya tersebut, hal ini sangat nampak jika keluarga lainnya atau rekannya datang ke hotel yang sama akan menyebutkan nama informan 2 sebagai perkenalan bahwa mereka merupakan keluarga dan kerabat dari informan 2.

Motivasi untuk mendapatkan penghargaan dan status juga nampak pada informan 3 dimana informan ingin memperlihatkan kepada orang lain, kerabat dan sekelompok orang tertentu tentang kemampuan dirinya yang sudah melakukan perjalanan untuk menjelajahi Indonesia. 


\section{National Conference of Creative Industry: \\ Sustainable Tourism Industry for Economic Development \\ Universitas Bunda Mulia, Jakarta, 5-6 September 2018 \\ ISSN No:}

\subsubsection{Pembahasan Analisis Kategori Motivasi}

Menurut MacInctosh \& Goeldner (1990), Ke empat kategori motivasi yaitu ; Physical motivations, Cultural Motivations, Interpersonal Motivations, Status dan Prestige Motivations merupakan motivasi yang dapat menjelaskan wisatawan dalam melakukan suatu perjalanan wisata

Motivasi wisatwan Timur Tengah jika dilihat dari ke empat kategori motivasi termasuk kepada motivasi fisik atau Physical Motivation dimana kujungannya ke Bandung untuk menikmati keindahan alam dengan cuaca yang sejuk, melakukan aktivitas rekreasi bersama keluarga yang dapat menimbulkan ketenangan dan kebahagiaan. Hasil penelitian tersebut sesuai dengan teori Sharpley, 1994 (dalam Pitana, 2005) yang menyatakan bahwa "motivasi merupakan pemicu dari proses perjalanan wisata, walaupun motivasi ini acapkali tidak disadari secara penuh oleh wisatawan itu sendiri".

\subsubsection{Data Penelitian Berdasarkan Faktor "Push" dan "Pull"}

Pada penelitian ini akan membahas factor oush" dan "pull" yang akan mempengaruhi perjalanan wisatawan Timur Tengah di Bangdung. 
National Conference of Creative Industry:

Sustainable Tourism Industry for Economic Development

Universitas Bunda Mulia, Jakarta, 5-6 September 2018

Tabel 4.8

Data Penelitian Berdasarkan Faktor "Push" dan "Pull"

Pengumpulan data penelitian pada aspek motivasi berdasarkan Faktor pendorong dan penarik ini dilakukan melalui wawancara dengan 3 informan dalam waktu yang berbeda, pada periode Desember 2016 sampai dengan Januari 2017.

\begin{tabular}{|c|c|c|c|c|c|}
\hline $\begin{array}{c}\text { Fokus } \\
\text { Penelitian }\end{array}$ & \multicolumn{2}{|c|}{$\begin{array}{l}\text { Sub fokus } \\
\text { penelitian }\end{array}$} & Informan 1 & Informan 2 & Informan 3 \\
\hline \multirow[t]{2}{*}{ 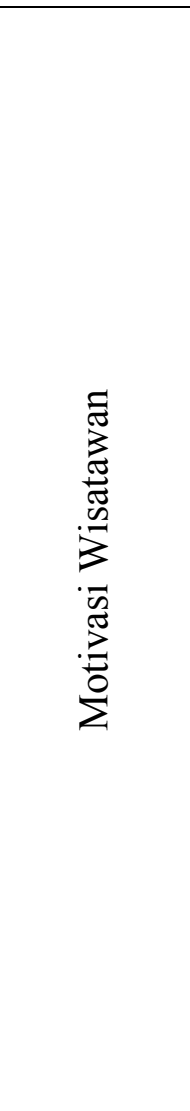 } & \multirow[t]{2}{*}{ 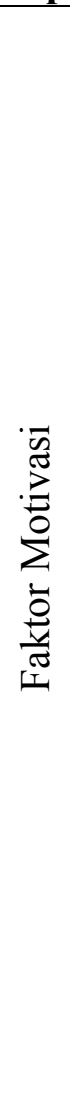 } & $\begin{array}{l}\text { Push } \\
\text { Factor }\end{array}$ & $\begin{array}{l}\text { karena ini merupakan perjalanan } \\
\text { traveling pertama kali, dan atas saran } \\
\text { dari sanak family nya yang sudah } \\
\text { berkunjung terlebih dahulu. informan } \\
\text { termotivasi bahwa dengan } \\
\text { kedatangannya ke bandung informan } \\
\text { akan mendapatkan relaksasi dari } \\
\text { aktivitas sehari - hari nya selama ini. }\end{array}$ & $\begin{array}{l}\text { yang menjadi alasan utama } \\
\text { informan untuk selalu mengunjungi } \\
\text { Bandung adalah keramah tamahan, } \\
\text { dan banyak kerabat yang ingin di } \\
\text { jumpai di Bandung. sebelum } \\
\text { kedatangannya ke bandung, } \\
\text { informan akan memberi tahu } \\
\text { perihal kedatangannya terlebih } \\
\text { dahulu kepada beberapa rekan dan } \\
\text { kerabatnya yang ada di Bandung. } \\
\text { kerabatnya ini merupakan beberapa } \\
\text { staff di hotel maupun restoran yang } \\
\text { memberikan service pelayanan } \\
\text { kepadanya yang dia anggap baik } \\
\text { dan dapat memabantu apa yang } \\
\text { informan butuhkan selama di } \\
\text { Bandung. }\end{array}$ & $\begin{array}{l}\text { faktor pendorong dari informan } 3 \\
\text { untuk kembali mengunjungi } \\
\text { Bandung yaitu untuk berbelanja } \\
\text { dan relaksasi }\end{array}$ \\
\hline & & $\begin{array}{c}\text { Pull } \\
\text { Factor }\end{array}$ & $\begin{array}{l}\text { Bandung memiliki udara yang sejuk, } \\
\text { pemandangan yang indah,dan } \\
\text { mayoritas penduduknya beragama } \\
\text { Islam membuat informan nyaman } \\
\text { untuk berada di Bandung.selain itu } \\
\text { juga informan ingin mendapatkan }\end{array}$ & $\begin{array}{l}\text { menurut informan } \text { Bandung } \\
\text { memiliki penduduk yang } \\
\text { ramah,sangat membantu, memiliki } \\
\text { kualitas akomodasi yang baik, } \\
\text { service yang excelent dengan harga } \\
\text { yang terjangkau,selain itu kelebihan }\end{array}$ & $\begin{array}{l}\text { Karena Bandung sangat cocok } \\
\text { untuk berlibur bersama sanak } \\
\text { famili, beragam daya tarik wisata } \\
\text { dan dapat memenuhi kepuasan } \\
\text { sanak famili terutama istri untuk } \\
\text { berbelanja karena Bandung }\end{array}$ \\
\hline
\end{tabular}


National Conference of Creative Industry:

Sustainable Tourism Industry for Economic Development

Universitas Bunda Mulia, Jakarta, 5-6 September 2018

ISSN No:

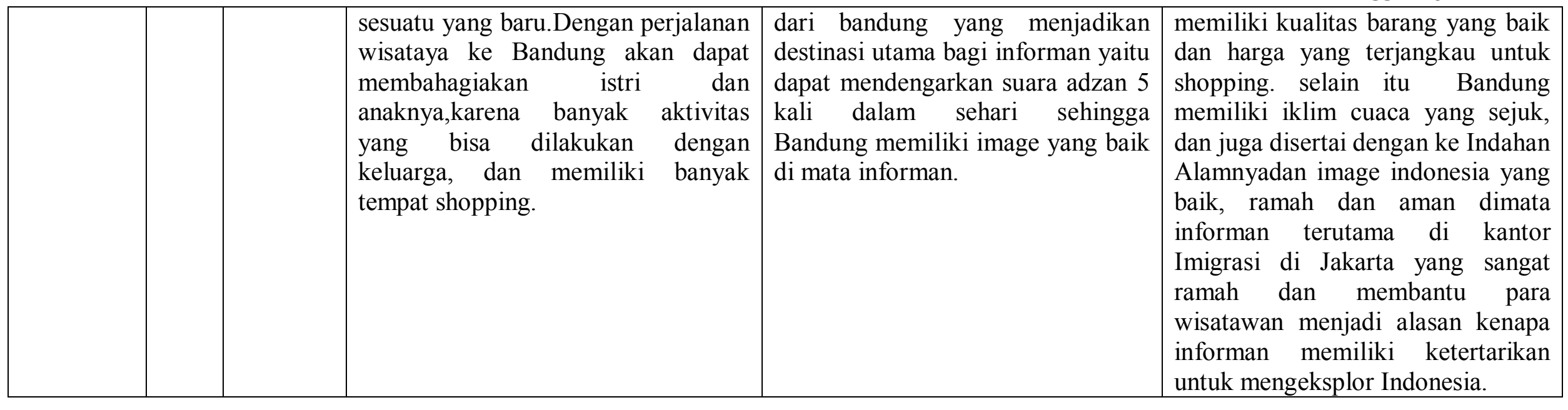




\section{National Conference of Creative Industry: \\ Sustainable Tourism Industry for Economic Development}

Universitas Bunda Mulia, Jakarta, 5-6 September 2018

ISSN No:

Pada tabel 4.8 menyatakan bahwa dikarenakan ini merupakan perjalanan pertama kali informan 1 ke Bandung,dan atas saran dari keluarga serta kerabat nya yang sudah melakukan perjalanan wisata ke Bandung terlebih dahulu bahwasanya dengan melakukan perjalanan wisata di Bandung informan akan mendapatkan relaksasi dari aktivitas sehari - harinya selama ini.rekomendasi ini lah yang menjadi push factor atau faktor pendorong informan 1 berkunjung ke Bandung. Sedangkan untuk informan 2 alasan utama untuk mengunjungi Bandung adalah keramah tamahan yang didapatkan selama di Bandung, dan banyaknya kerabat yang ingin di jumpai. Sebelum kedatangannya ke Bandung, informan akan member tahu perihal rencana perjalanan wisatanya terlebih dahulu kepada kerabat - kerabatnya. Kerabat yang dimaksud ini merupakan beberapa staff hotel, restoran dan masyarakat local lainnya yang di anggap oleh informan memberikan pelayanan yang baik dan membantu kebutuhan informan selama di Bandung. Sedangkan faktor pendorong Informan 3 melakukan perjalanan wisata ke Bandung yaitu untuk berbelanja dan relaksasi.

Sedangkan pada tabel 4.8 faktor penarik atau pull factor yang menjadi alas an informan 1 memutuskan untuk melakukan perjalanan wisata ke Bandung yaitu ; Bandung memiliki udara yang sejuk, pemandangan yang indah, dan mayoritas penduduk nya beragama islammembuat informan nyaman dan tenang untuk berada di Bandung. Selain itu juga informan 1 ingin mendapatkan sesuatu yang baru dan dengan perjalanan wisatanya ke Bandung informan 1 berharap dapat memuaskan dan membahagiakan pasangan beserta anaknya, karena Bandung memiliki banyak daya tarik wisata dan aktivitas yang dapat dilakukan bersama keluarga dan juga bandung memiliki banyak tempat untuk berbelanja.

Menurut informan 2 Bandung memiliki penduduk yang ramah, sangat membantu, memiliki daya tarik wisata yang bagus, memiliki kualitas akomodasi yang baik, service atau pelayanan yang sangat memuaskan dengan harga yang sesuai. Selain daripada itu, yang menjadikan Bandung destinasi utama bagi informan yaitu dapat mendengarkan suara adzan lima kali dam sehari sehingga Bandung memiliki citra yang baik dimata informan 2.

Menurut informan 3 Bandung sangat cocok untuk berlibur bersama keluarga karena memiliki daya tarik wisata yang baik untuk dapat dikunjungi bersama keluarga, dan dapat memenuhi kepuasan sanak keluarga terutama istri untuk berbelanja. Bandung memiliki barang - barang yang di perjual belikan dengan kualitas baik dan harga yang sangat terjangkau, selain itu bandung memiliki cuaca yang sejuk yang di sertai dengan keindahan alamanya serta citra Bandung yang baik di mata informan 3 membuat informan 3 akan selalu menghabiskan masa libur bersama keluarganya di Bandung.serta keramah tamahan yang di tunjukkan oleh kantor imigrasi di Jakarta dapat memotivasi informan 3 memiliki ketertarikan untuk menjelajahi Indonesia.

\subsubsection{Pembahasan Analisis Faktor "Push" dan "Pull"}

Melalui analisis faktor pendorong dan faktor penarik wisatawan Timur Tengah untk melakukan perjalanan di Bandung, faktor pendorong yang terbentuk dari karakter wisatawan Timur Tengah yaitu Rest \& Relaxation, untuk menikmati pemandangan alam, Prestige dan interaksi sosial. Karena faktor pendorong merupakan faktor yang harus dapat memberikan rangsangan dan motivasi pada setiap wisatawan dan sebagian besar kator pendorong ada di dalam keinginan di setiap masing - masing individu, seperti yang dikatakan oleh Dann (1977) "these are internal or intangible factor that lead to the formation of travel desire among potential tourists" 
Sedangkan faktor penarik menurut Dann (1977) yaitu "these are factors that influence where tourists go travelling. pull factors are the attractiveness or "drawing power" of the destination as perceived by the traveler, and they are likely help traveler to make an actual destination choice ".

Jika dilihat dari teori tersebut, faktor penarik wisatawan Timur Tengah yaitu ;banyaknya aktivitas yang daoat dilakukan dengan keluarga, safety, keindahan alam dengan udara yang sejuk, banyak nya variasi tempat berbelanja dengan kualitas barang - barang yang high quality dan harga yang terjangkau. Positif imej yang ada di wisatawan Timur Tengah mengenai Bandung, yaitu Bandung sebagai kota yang Islami.

\subsection{Hasil Analisis dan Pembahasan Bentuk Pola Pergerakan}

Dalam sebuah pola pergerakan selain dilihat dari faktor - faktor motivasi yang dapat mempengaruhi serta pengklasifikasian wisatawan terdapat juga beberapa kategori pola pergerakan wisatawan (tourist movement patterns).

\subsubsection{Data Penelitian berdasarkan Bentuk Pola Pergerakan}

Berdasarkan data yang mengacu pada tabel 4.1 tentang daya tarik wisata, perjalanan wisata untuk menjelajahi daya tarik wisata untuk wisatawan Timur Tengah memiliki kebiasan atau pola yang sama sesuai dengan saran yang di berikan oleh family dan rekan nya yang sudah terlebih dahulu berkunjung ke Bandung atau pun saran yang diberikan oleh staff hotel. wisatawan Timur Tengah melakukan perjalanan wisata di Bandung, berikut bentuk pola yang tergambar berdasarkan itinerary yang wisatawan Timur Tengah miliki:

Gambar 4.1

Bandung Barat - Subang

Hari pertama perjalanan wisata wisatawan Timur Tengah akan menjelajahi Bandung Barat dan Subang.

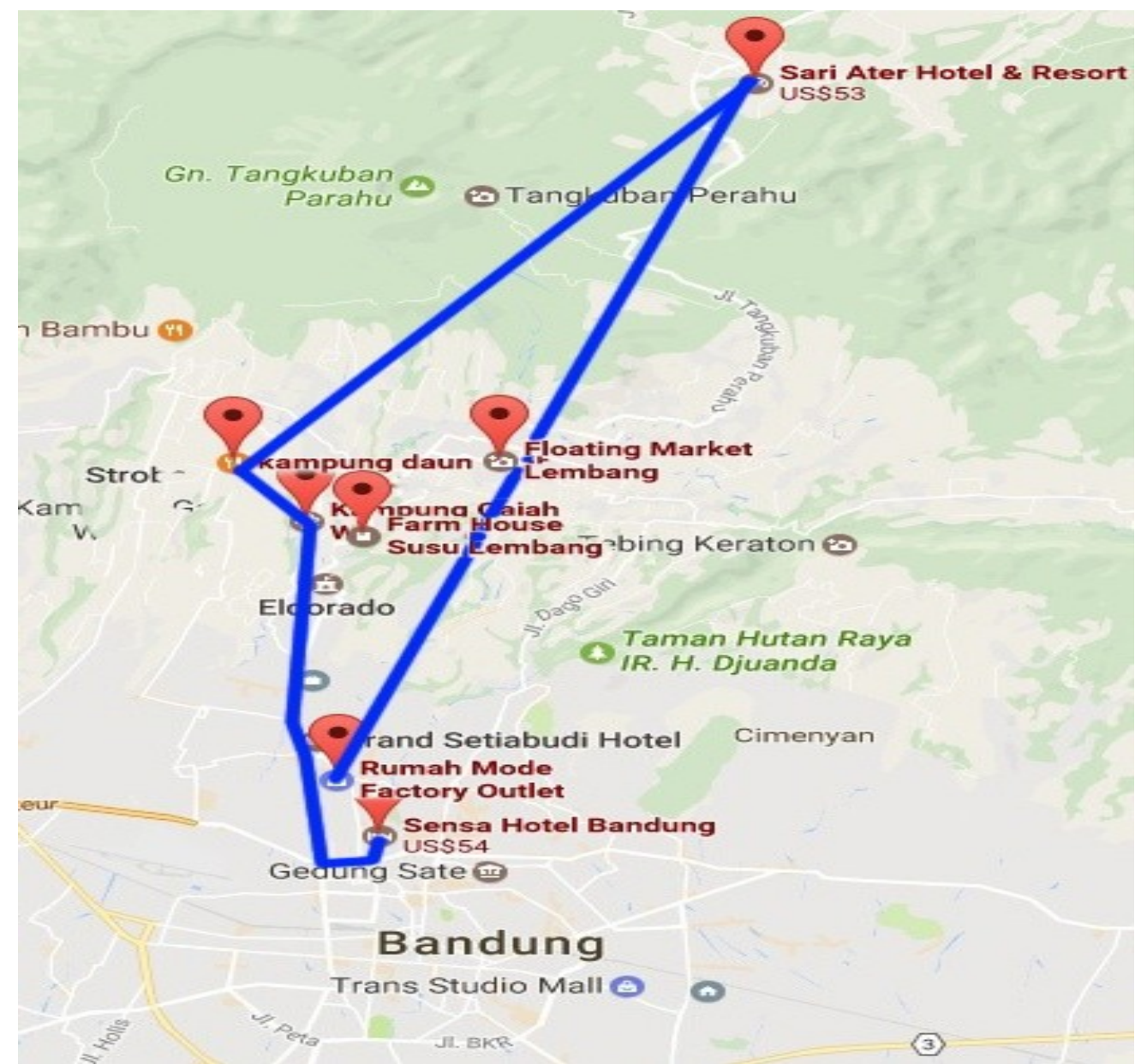


Sumber: https://www.google.co.id/maps/ , 2017

Berdasarkan Gambar 1 Dimana Wisatawan Timur Tengah akan melakukan perjalanan yang di mulai di dari Hotel yang memang berada di tengah kota kemudian menuju Bandung Barat yaitu Lembang, dengan atraksi wisata : Kampung gajah, Kamung Daun, lalu menuju Kota Subang dengan atraksi wisata Pemandian Air Panas Sariater, dan kembali ke Lembang yaitu menuju floating market, kemudian turun ke bawah menuju Kota Bandung yaitu menuju wisata belanja Rumah Mode dan kemudian kembali ke hotel.

Gambar 4.2

Kabupaten Bandung

Hari kedua perjalanan wisata wisatawan Timur Tengah akan menjelajahi Kabupaten Bandung.

Sumber: https://www.google.co.id/maps/ , 2017

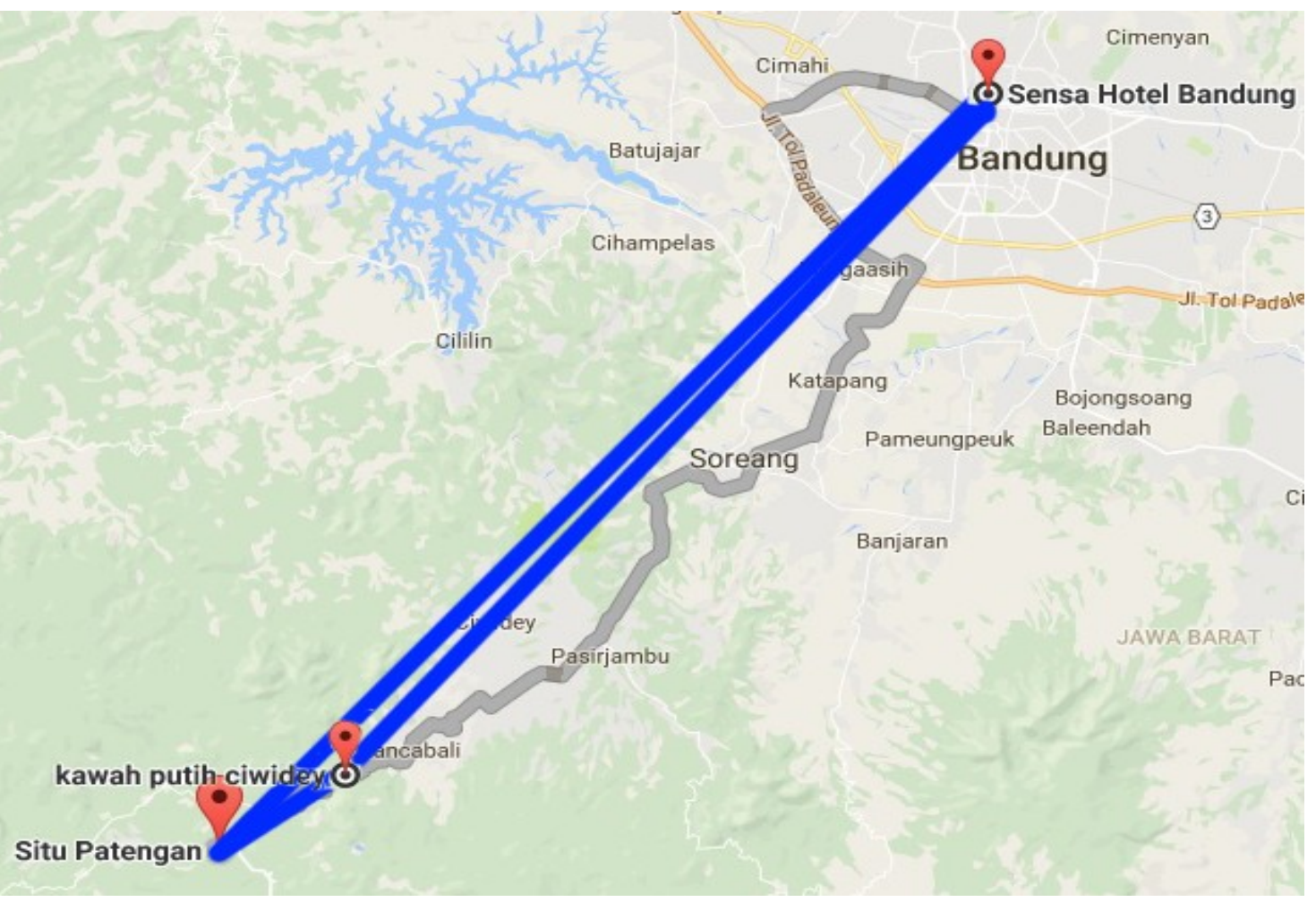

Berdasarkan gambar 2 untuk hari beriktnya wisatawan Timur Tengah akan menjelajahi Kabupaten Bandung, biasanya wisatawan beraktifitas setelah breakfast, karena wisatwan Timur Tengah tidak memiliki kepastian dengan waktu untuk memulai perjalanan pun tidak pasti. Untuk perjalan menuju Kabupaten Bandung sesampainya di kawah putih sebelum pukul $12.00 \mathrm{pm}$, kemudian di lanjutkan makan siang di local restoran, strawberry farm dan kemudian dilanjutkan ke danau situ patenggang dan kemudian kembali ke Hotel.

\subsubsection{Pembahasan Penelitian berdasarkan Bentuk Pola Pergerakan}

Berdasarkan pola perjalanan yang dilakukan oleh wisatawan Timur Tengah dilihat berdasarkan motivasi bahwasanya bentuk pola pergerakan yang dilakukan oleh wisatwan Timur Tengah yaitu menggunakan model Destination Region Loop.

Gambar 4.3 


\section{Model Destination Region Loop}

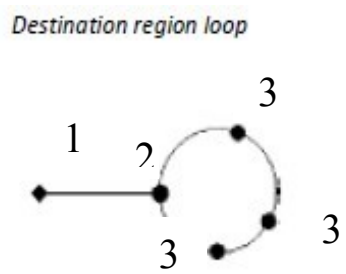

Perjalanan wisatawan dimulai dengan meninggalkan akomodasi atau tempat mereka menginap (1) menuju destinasi atau daya tarik utama (2) kemudian dilanjutkan dengan rute mengelilingi destinasi sekunder atau daya tarik disekeliling daya tarik utama (3). Setelah menyelesaikan tur secara berkeliling (pola lingkaran), mereka kembali ke tempat asal melalui rute yang paling singkat antara tujuan utama dan tempat asal berangkat.Ini merupakan kombinasi dari pola single point dan chaining loop.

Berdasarkan tabel 4.5 mengenai tipologi wisatan, wisatwan Timur Tengah termasuk kedalam tipe near phsichocentric dan cenderung mendekai mid-centric, sehingga Pola pergerakan wisatawan Timur Tengah di Bandung mengalami keseragaman antara wisatawan Timur Tengah yang satu dan yang lainnya, dan akan memilih daya tarik wisata yang populer. Sehingga model destination region ini dianggap model yang paling cocok untuk wisatawan Timur Tengah dilihat berdasarkan profil wisatawan dan motivasi pola pergerakan.

\section{KESIMPULAN DAN IMPLIKASI}

\subsection{Kesimpulan}

Pada bab ini peneliti akan menyimpulkan hasil penelitan tentang pola perjalanan wisatawan Timur Tengah di Bandung berdasarkan profil wisatawan dan motivasi pola pergerakan dan memberikan saran serta rekomendasi untuk pemerintah dan para pelaku usaha pariwisata dan perjalanan.

Profil wisatawan dan motivasi adalah dua aspek yang sangat mempengaruhi pola perjalanan wisatawan Timur Tengah ketika berkunjung ke Bandung. Dalam hal ini pengaruh terhadap pola perjalanan ditunjukkan dengan pemilihan terhadap daya tarik wisata tertentu dengan fasilitas dan komponen - komponen aksesibilitas yang digunakan untuk mendukung kegiatan wisata.

1.Aspek Profil Wisatawan dan Motivasi Pola Pergerakan Wisatawan

a. Wisatawan timur tengah tergolong wisatawan kelas menengah keatas sehingga lebih menyukai terhadap pemilihan barang - barang mewah atau luxury goods. Selain itu mereka cukup royal baik dalam pengeluaran maupun pemberian tip terutama jika wisatawan Timur Tengah merasa mendapatkan kualitas pelayanan yang baik dan memuaskan dari para service provider.

b. Wisatawan TImur Tengah termasuk ke dalam kategori wisatawan near phsichocentric dan cenderung mendekati mid-centric. Hal ini ditunjukan dalam pemilihan terhadap daya tarik yang lebih familiar, umum dan dapat mengingatkan mereka terhadap suasana atau lingkungan di Negara asal mereka.Tingkat familiaritas dari pemilihan daya tarik wisata ini 


\section{National Conference of Creative Industry: \\ Sustainable Tourism Industry for Economic Development}

Universitas Bunda Mulia, Jakarta, 5-6 September 2018

ISSN No:

diukur berdasarkan informasi yang mereka dapatkan dari internet, kerabat dan keluarga yang sebelumnya sudah melakukan perjalanan wisata di Bandung.

c. Wisatawan Timur Tengah yang melakukan perjalanan wisata di Bandung termasuk segmentasi wisatawan yang berpasangan atau keluarga.

2. Aspek daya tarik wisata, aksesibilitas dan fasilitas yang mempengaruhi pola perjalanan wisatawan Timur Tengah di Bandung.

a. Profil wisatawan dan motivasi tersebut yang sangat mempengaruhi terhadap pemilihan akomodasi, restaurant, daya tarik yang dikunjungi serta fasilitas yang diberikan. Untuk akomodasi para wisatawan Timur Tengah memilih hotel berbintang 4 dan resort yang setara dengan hotel berbintang.Memilih menu restaurant yang berbahan dasar daging kambing, memilih daya tarik yang memberikan relaksasi.

b. Dilihat dari tipologi wisatawan, wisatawan Timur Tengah tidak menggukanan tour operator untuk mengatur perjalanan wisatanya selama berada di Bandung.

c. Aksesibilitas yang digunakan selama perjalanan wisata menggunakan mobil pribadi yang di sewa beserta drivernya selama mereka berada di suatu daerah wisata.

\subsection{Implikasi}

Perjalanan wisata merupakan bagian dari kepariwisataan yang merupakan kegiatan dengan multi-dimensi dan dibutuhkan kerja sama dari berbagai pihak yang terkait.oleh karena itu rekomendasi ini diharapkan mampu menjadi masukan dan pertimbangan terutama untuk pemerintah daerah dan para pelaku usaha di bidang akomodasi dan perjalanan dalam nendukung sekaligus mendorong kunjungan wisatawan Timur Tengah ke Bandung, dengan beberapa hal, yaitu :

1. Untuk pihak hotel berbintang 4 maupun resort setaraf bintang diharapkan staff hotel, pelayanan dan fasilitas lainnya dapat memberikan pelayanan terbaik yang bersifat personal touching. Karena hal tersebut akan membuat wisatawan Timur Tengah merasa di hargai. Maka rekomendasi yang diberikan yaitu,

a. Supervisor bertanggung jawab dan mampu memastikan setiap anggota atau staff yang berada di garda terdepan seperti divisi front office dan Guest relation officer memberikan pelayanan yang tulus dan memiliki prioritas atau atensi lebih kepada setiap tamu terutama tamu yang berasal dari Timur Tengah.

2. Adanya pelatihan bahasa Arab, rekomendasi yang di antaranya adalah ;

a. Hotel : manajemen hotel memberikan pelatihan khusus bahasa Arab terutama untuk staff yang berinteraksi langsung dengan tamu, dengan mendatangkan para ahli bahasa Arab.

b. Restaurant : untuk restaurant tematik, khusus untuk restaurant yang menyajikan menu Timur Tengah, harus memiliki staff ahli yang memiliki kemampuan berbahasa Arab. Hal ini dapat dimanfaatkan untuk melatih dan mengajarkan staff lainnya agar lebih mandiri dalam menghadapi tamu wisatawan Timur Tengah.

c. Guide : Memiliki keahlian dalam berbahasa Arab dan juga memiliki keahlian mengendarai kendaraan beroda 4. Karena wisatawan timur tengah jangan sekali menggunakan guide professional yang hanya bekerja sebagai pemandu. Namun wisatawan timur tengah lebih memilih 


\section{National Conference of Creative Industry: \\ Sustainable Tourism Industry for Economic Development}

Universitas Bunda Mulia, Jakarta, 5-6 September 2018

ISSN No:

pekerja yang bukan hanya berprofesi sebagai pemandu namun juga bisa sebagai driver.

3. Untuk Pemerintah Daerah, Dinas Kebudayaan dan Pariwisata, Badan Promosi Pariwisata Kota Bandung yang bekerja sama dengan usaha jasa pariwisata dan stakeholder di bidang pariwisata untuk mendukung dan mendorong kunjungan wisatawan Timur Tengah. Rekomendasi yang dapat diberikan yaitu :

a. Membuat bahan dan materi promosi destinasi wisata baru di Bandung dalam bahasa Arab, terutama untuk promosi daya tarik wisata rafting, outbound .agar dapat memperluas perspektif baru terhadap produk wisata di benak wisatawan Timur Tengah.

b. Membuat dan menyediakan sumber informasi mengenai daya tarik wisata, informasi fasilitas dan aksesibilitas yang mendukung kegiatan pariwisata di Bandung, informasi jasa penyewaan transportasi yang driver nya memiliki keahlian berbahasa Arab, informasi restauranyt,dan shopping center khusus untuk wisatawan Timur Tengah baik dalam bentuk Map, Brosur maupun advertising dalam bahasa Arab.

\section{DAFTAR PUSTAKA}

\section{Artikel dalam Jurnal Publikasi}

Ariffin dan Hasim. 2009. Marketing Malaysia to the Middle East Tourist: Toward A preferred Inter-regional Destinations. International Journal of West Asian Studies. Vol. 1, (pp 39-53)

Hazbun. 2006. Explainning the Arab Middle East Tourism Paradox. Toronto: The Arab World Geographer/Le Géographe du monde arabe. Vol 9, No 3

Hancock, et al. 2009.An Introduction for Qualitative Research. National Institute fo Health Research.

Kovjanic. 2014. Islamic Tourism as a Factor of the Middle East Regional Development. TURIZAM. Volume 18, Issue 1 33-43

MacLeod, D.V. 2004. Tourism, Globalization and Cultural Change: An Island Community Perspective. Series: Tourism and cultural change. Channel View Publications: Clevedon, England.

Manajemen Perjalanan. 2016. Laporan Small Scale Research: Perencanaan Pola Perjalanan Wisata Heritage di Kota dan Kabupaten Cirebon. Pasca Sarjana, Sekolah Tinggi Pariwisata Bandung

Paturusi, Syamsul Alam. 2008. Perencanaan Kawasan Pariwisata. Denpasar: Udayana University Press. 
Sekaran, Uma. 2003. Research Methods for Business: A Skill-Building Approach 4th Edition. John Wiley \& Sons, Limited. Academic Internet Publishers Incorporated.

\section{Buku}

Collier, Alan. 2004. Principles of Tourism: A New Zealand Perspective 6th Edition.

Creswell, John W. 2014. Research Designed Pendekatan Kualitatif dan Mixed. Yogyakarta: Pustaka Pelajar.

Engel, James, F, Roger D. Blackwell, dan Paul W. Miniard. 1994. Perilaku Konsumen. Edisi Keenam. Jilid 1. Penerbit Binarupa Aksara. Jakarta.

Foster, Douglas. 1985. Travel and Tourism Managemen. London: Macmillan Press LTD.

Ismayanti. 2010. Pengantar Pariwisata. Jakarta: Grasindo

McIntosh Robert W., Charles R. Goeldner. 1990. Tourism: Principles, Practices, Philosophies 6th Edition. Wiley

Miles, M.B. dan A.M. Huberman. 1994. Qualitative Data Analysis. California: SAGE Publications Inc.

Moleong, Lexy. J. 2004. Metode Penelitian Kualitatif. Remaja Rosdakarya. Bandung.

Nuriata. 2014. Paket Wisata: Penyusunan Produk dan Penghitungan Harga. Bandung: Alfabeta.

Spillane, James J. (2003). Pariwisata dan Wisata Budaya, CV. Rajawali.

Sugiyono. 2011. Metode Penelitian Kuantitatif, Kualitatif dan R\&D.Bandung: Alfabeta. .2013. Metode Penelitian Bisnis: Kuantitatif, Kualitatif dan R\&D. Bandung: Alfabeta.

Sumarwan, Ujang. 2004. Perilaku Konsumen Teori dan Penerapannya dalam Pemaasaran.Bogor : Penerbit Ghalia Indonesia.

Timothy, Dallen J. 2005. Shopping Tourism, Retailing and Leisure. UK: Frankfurt Lodge, Clevedon Hall.

Yoeti, O.A. 1997. Perencanaan dan Pengembangan Pariwisata. Jakarta: PT Pradnya Paramita

\section{Artikel dari konferensi ilmiah/prosiding}


Education Bureau. 2013. Tourism and Hospitality Studies. Hongkong: Personal, Social and Humanities Education Section, Education Bureau.

Ibrahim, Zulkifli, dkk. 2009. Travelling Pattern and Preferences of the Arab Tourists in Malaysian Hotels (Int. Journal). Selangor, Malaysia: www.ccsenet.org/journal.html .International Journal of Business and Management. Vol 4, No. 7

Koswara, Ina Herliana. 2002. Karakteristik Wisatawan; Siapa dan Bagaimana Mereka Berwisata.Warta Pariwisata Pusat Penelitian Kepariwisataan (P2PAR) Lembaga Penelitian ITB. Vol V, No. 3

Lew dan McKercher. 2005. Modeling Tourist Movement: A Local Destination Analysis. Annals of Tourism Research. Vol. 33, No. 2, pp. 403-423

Zin, dkk. 2013. The Potential of Arabic as a Tourism Language in Malaysia. MCSER Publishing: Rome-Italy. Journal of Educational and Social Research. Vol. 3 No.7

https://www.google.co.id/maps/place/Bandung,+Bandung+City,+West+Java/ diakses pada 10 Maret 2017.

\section{Disertasi/tesis/skripsi}

Desa, Surya. 2008. Pengaruh Sosio-demografi dan Karakteristik Pekerjaan Terhadap Keinginan Pindah Kerja di Kabupaten Serdang Bedagai (Tesis). Medan: Universitas Sumatra Utara Medan.

Lau dan McKercher. 2006. Understanding Tourist Movement Patterns in a Destination: A GIS Approach. Palgrave Macmillan. Tourism and Hospitality Research. Vol. 7, 1, 39-49

\section{Sumber Elektronik/Internet}

Badan Pusat Statistik. 2010. Jumlah Kunjungan Wisatawan Mancanegara.

Kementrian Kebudayaan dan Pariwisata. 2010. Review Rencana Strategis: Kementrian Kebudayaan dan Pariwisata tahun 2010 - 2014. Jakarta.

Kementrian Pariwisata. 2015. Rencana Strategis: Pengembangan Destinasi dan Industri Pariwisata 2015 - 2019. Jakarta.

Undang-undang Republik Indonesia No.10 tahun 2009 tentang Kepariwisataan 


\section{BIODATA}

\section{NUKEU NOVIA ANDRIANI SURYADI}

\section{CONTACT DETAILS}

Address

: Citraland Bagya City Blok R8 No 07 Medan Estate, Percut Sei Tuan Deli Serdang, Medan.

Phone (Mobile) : :081808467988

Email Address : nukeunovia@gmail.com

\section{PERSONAL PARTICULARS}

$\begin{array}{llll}\text { Age } & : 29 \text { years } & \text { Date of Birth } & : 30^{\text {th }} \text { Nov } 1988 \\ \text { Nationality } & : \text { Indonesia } & \text { Gender } & : \text { Female } \\ \text { Marital Status } & : \text { Marriage } & \text { Health } & : \text { Excellent } \\ \text { Permanent Residence } & : \text { Bandung } & & \end{array}$

1. Level : Master Degree

Field of Study : : Tourism and Travel Management

Name of Institution : Bandung Institute of Tourism

Location : Bandung

2. Level

Field of Study

: Degree

: English Literature

Name of Institution : Indonesian University of Education

Location

: Bandung

3. Level

Major

: Senior High School

Name of Institution

Location

: Science

SMA Negeri 2 Cirebon

: Cirebon

Grade : passed

4. Level

: Junior High School

Grade : Passed

Name of Institution

: SMP Negeri 5 Cirebon

Location

: Cirebon

Grade : passed

5. Level

: Primary School

Grade : Passed

Name of Institution

: SDN Tambi 1

Location

: Indramayu 


\section{Company Name : JEREJAK RAINFOREST RESORT Penang - Malaysia \\ Position Level : Front Office Assistant (Trainee) \\ Specialization : Front Office ; Multitasking \\ Date Joined : January 2011 - July 2011 \\ Work Description}

- Resposible for efficient and courteous communication with guests for all arrival and departure procedures.

- Responsible to providing courteous telephone services for guests as well as providing guest information on hotel facilities.

- Handling the cashiering for lodging, recreation activities, etc.

Company Name : SENSA HOTEL - Bandung

Position Level : Front Office (Daily Worker)

Specialization : Operator ; Multitasking

Date Joined : November 2011 - May 2012

Work Description :

- Responsible to providing courteous telephone services for guests as well as providing guest information on hotel facilities.

Company Name : : SENSA HOTEL - Bandung

Position Level : Guest Service Assistance

Specialization : Front Office

Date Joined : May 2012 - May 2013

Work Description :

- Resposible for efficient and courteous communication with guests for all arrival and departure procedures.

- Responsible to providing courteous telephone services for guests as well as providing guest information on hotel facilities.

- Supervises all reception functions with special attention to the reservation aspect especially room allocation with travel agents, internet booking and telephone booking

Company Name : : Lintang Buana Wisata Nusantara

Position Level : : Bandung Representative

Date Joined : November 2014 - August 2015

Work Description :

- The role plays a vital part in the administration and smooth-running of businesses throughout industry.

- involved with the coordination and implementation of office procedure and frequently have responsibility for specific projects and tasks and, in some cases, oversee and supervise the work of junior staff. 
- Getting information about areas of interest in order to target more clients in particular seasons.

- Ensuring that clients have access to various services without a hitch.

- Provide information about the best destinations places, tours, accommodation and transport.

- Organizing promotional materials for the company.

- Addressing any complaints that could arise from the customers.

- To notify clients of their bookings and days of travel.

- attending meetings, taking minutes and keeping notes

- managing and maintaining budgets

- liaising with staff in other departments and with external contacts

- recruiting, training and supervising junior staff and delegating work as required

Company Name : SENSA HOTEL - Bandung

Position Level : Guest Service Assistance

Specialization : Front Office

Date Joined : : August 2015 - October 2016

Work Description :

- Resposible for efficient and courteous communication with guests for all arrival and departure procedures.

- Responsible to providing courteous telephone services for guests as well as providing guest information on hotel facilities.

- Supervises all reception functions with special attention to the reservation aspect especially room allocation with travel agents, internet booking and telephone booking

Company Name : LAUT BIRU HOTEL - PANGANDARAN

Position Level : Marketing Manager

Specialization : Sales \& Marketing

Date Joined : : December 2016-2017 February

Work Description :

- Implementing a proactive room sales strategy

- Developing both new and existing customer

- In larger groups, maintaining key accounts with national companies.

- Promoting the brand

Company Name

Position Level

Specialization

Date Joined
: TAMAN GOA SUNYARAGI

: Public Relation

: Sales \& Marketing

: February - July 2017

Work Description :

- Planning publicity strategies

- Dealing with inquiries from the public, the press, and related organizations.

- Speaking publicly at interviews, press conferences and presentations. 
Position Level : Project Manager

Date Joined : : August 2017 - June 2018

Work Description :

- Lead the project to fit on the GMP milestone

- Ensure resource availability and allocation.

- Assembling and leading project team.

- Coordinating internal resources and vendors / third party of the project.

- Ensuring that all projects are delivered on time, within scope and the budget

- Manage the relationship with the client and all stakeholders.

- Manage issues and risk

- Report to management as needed.

Company Name : Wilmar Bisnis Institute

Position Level : Lecturer

Date Joined : July 2018 - Sekarang

Work Description :

- Lecture planning, preparation and research

- Contact and teaching time with students

- Checking and assessing students' work

- Invigilating examinations

- Writing research proposal and paper

- Attending and speaking at conferences and seminars

\section{SKILLS}

SKILLS

- Trainer

- Internal Verifier

\section{Proficiency}

Certified IATA - singapore for Train the Trainer Certified by Pearson - London 